\title{
Articles
}

\section{Regulatory Costs of Mythic Proportions}

\author{
Lisa Heinzerling ${ }^{\dagger}$
}

\section{CONTENTS}

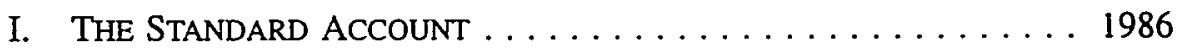

A. The Table . . . . . . . . . . . . . . . . . . . . . . . 1989

B. The Table's Influence ... . . . . . . . . . . . . 1993

II. TABLE OF LEgENDS . . . . . . . . . . . . . . . . . . . . . . 1998

A. Choosing the Rules for the List: Overinclusion and

Underinclusion ... . . . . . . . . . . . . . . . 1999

1. Overinclusion: Rules Rejected Because Their Benefits Did

Not Exceed Their Costs . . . . . . . . . . . . . 2000

a. Benzene (EPA 1984) . . . . . . . . . . . . 2000

b. Radionuclides (EPA 1984) . . . . . . . . . . 2004

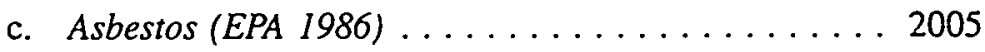

d. Acrylonitrile (OSHA 1978) . . . . . . . . . 2008

e. Summary .................... 2010

2. Overinclusion: Rules That Do Not Exist . . . . . . . 2010

a. Ethylene Dibromide (OSHA 1983) . . . . . . . 2010

b. Arsenic and Copper Smelters (EPA 1986) ...... 2011

c. Arsenic and Glass Manufacturing Plants (EPA 1986) 2013

d. Radionuclides and Uranium Mines (EPA 1984) ... 2013

e. Summary ... . . . . . . . . . . . . . 2014

3. Underinclusion: Excluded Rules and Failures To Regulate 2014

4. Conclusion ..................... 2017

$\dagger$ Professor of Law, Georgetown University Law Center. For helpful comments and discussion, I am grateful to Robert Ellickson, Richand Lazanus, John F. Morrall III, Susan Rose-Ackerman. Louis Michael Seidman, Girardeau Spann, Cass Sunstein, Mark Tushnet, Robin West, and participants in law school faculty workshops at Duke, Georgetown, Northwestern. the University of Pennsylvania. Washington University, and Yale. John Ritsick and Jo-Ellyn Sakowitz Klein provided exceptional research assistance. 
B. Competing Estimates of Costs per Life Saved . . . . . . . 2017

1. Discounting . . . . . . . . . . . . . . . 2018

a. Asbestos (OSHA 1972), Acrylonitrile (OSHA 1978), and Arsenic (OSHA 1978) . . . . . . . . . . . 2018

b. Arsenic and Low-Arsenic Copper Smelters (EPA 1986) 2020

c. Arsenic and Glass Manufacturing Plants (EPA 1986) 2022

d. Asbestos (OSHA 1986) . . . . . . . . . . . . 2024

e. Summary . . . . . . . . . . . . . . . . . . . . . 2024

2. Estimating Risks . . . . . . . . . . . . . 2025

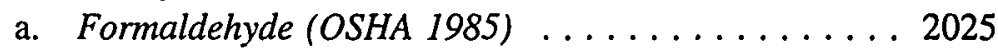

b. Land Disposal (EPA 1986) . . . . . . . . . . . . . 2028

c. Uranium Mill Tailings (EPA 1983) . . . . . . . 2030

d. Coke Ovens (OSHA 1976) . . . . . . . . . . 2032

e. Ethylene Oxide (OSHA 1984) . . . . . . . . . . 2034

f. Benzene (OSHA 1985) . . . . . . . . . . . . 2037

g. Summary ..................... 2038

3. Conclusion .................... 2038

III. THE PERILS of PRECISION . . . . . . . . . . . . . . . . . . . . . 2042

A. Numerical Values . . . . . . . . . . . . . . . . . . . . 2042

1. Discounting Lives . . . . . . . . . . . . . . . 2043

2. Quantitative Risk Assessment . . . . . . . . . . 2056

3. Regulatory Purposes . . . . . . . . . . . . . . 2060

4. Conclusion ....................... 2064

B. Danger in Numbers . . . . . . . . . . . . . . . . . 2064

1. More Words? . . . . . . . . . . . . . . . 2064

2. More Numbers? . . . . . . . . . . . . . . 2067

3. Conclusion ................... 2068

IV. Conclusion . . . . . . . . . . . . . . . . . . . . 2069 
Any close observer of the regulatory process has learned by now that the government often requires the expenditure of a huge sum of money - sometimes billions of dollars-to save a single human life. She has also learned that there are many regulatory options available that would produce the same benefits at a far lower cost. She has learned these things largely from a table prepared during the 1980s by an economist at the Office of Management and Budget named John Morrall. This table shows the cost per life saved of various risk-reducing federal regulations. According to the table, this cost varies dramatically from regulation to regulation, from a low of $\$ 100,000$ per life saved to a high of $\$ 72$ billion. One-third of the regulations on the list reportedly cost over $\$ 100$ million for every life they save.'

These numbers are ubiquitous in the literature on risk regulation. Numerous scholars have relied on Morrall's table, as well as earlier and later versions of it, in arguing that the costs of regulation often exceed its benefits, that many more cost-effective strategies exist for reducing risk, that regulation sometimes increases overall risk, and that regulatory priorities are not set in a rational manner. ${ }^{2}$ Morrall's calculations, in short, have been used to support every one of the most prominent current critiques of the regulatory system. They have also played a significant role in political debates over regulatory reform, including most recently the debates surrounding the Republicanproposed Contract with America. ${ }^{3}$

1. See John F. Morrall III, A Review of the Record. Regulation, Nov/Dec. 1986, at 2S, 30 tbl.4.

2. This is a sampling of the scholarly sources relying on one or another version of Morrall's table to make at least one of these arguments: STEPHEN BREYER. BREAKING THE VICIOUS CIRCLE: TOWARD EFFECTIVE RISK REgULATION 24-27 (1993): W. KIP VISCUSI. Fatal TRADEofFS: PUbliC aNd PRIVATE RESPONSIBILITIES FOR RISK 264 tbl.14-5 (1992); Clayton P. Gillette \& Thomas D. Hophıns. Federal Agency Valuations of Human Life, in ADMINISTRATIVE CONFERENCE OF THE U.S., REPORT FOR RECOMMENDATION 88-7, at 368, 368-69 (1988); Randall Lutter \& John F. Monall III. Health-Healsh Analysts: A New Way To Evaluate Health and Safety Regulation, in THE MORTALITY COSTS OF REGULATORY EXPENDTURES 43. 59 tbl.6 (W. Kip Viscusi ed., 1994); Cass R. Sunstein, Healhh-Healh Tradeoffs, 63 U CuI. L. REV. IS33, 1547-48 tbl.2 (1996) [hereinafter Sunstein, Health-Health Tradeoffs]: Cass R. Sunstetn. Paradaxes of the Regulatory State, 57 U. CHI. L. REv. 407, 410 (1990) [hereinafter Sunstein. Paradoxes]: W. Kip Viscusi, Regulating the Regulators, 63 U. CHI. L. REv. 1423, 1430-36 \& tbl.1 (1996): Kenneth J. Arrow el al.. Is There a Role for Benefit-Cost Analysis in Environmental, Health, and Safery Regularion'. 272 SCIEvCE 221. 221 (1996); and Richard J. Zeckhauser \& W. Kip Viscusi. Risk Within Reason. 248 SCIENCE 559. S62-63 (1990).

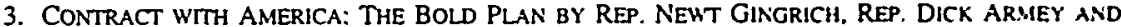
THE HOUSE REPUBLICANS TO CHANGE THE NATION (Ed Gillespie \& Bob Schellhas eds.. 199:) (hereinafter CONTRACT WITH AMERICA]; see also, e.g., Regulatong Reform: Hearung on S. 343 Before the Senate Comm. on the Judiciary, 104th Cong. 87 (1995) (hereinafter Regulaton Reform Judictar Comm. Hearngl (testimony of Cass R. Sunstein, Professor, University of Chicago Law School): Joint Heurng on the Impact of Workplace and Employment Regulation on Business: Hearng Before the Subcomm. on Oversight and Investigations of the House Comm. on Econ. and Educ. Opportunules and the Subcomm. on Regulation and Paperwork of the House Comm. on Small Bus., 104th Cong. 32 (1995) (hereinafter Joint Hearing] (testimony of Rober W. Hahn, Resident Scholar, American Enterprise Inst.): 141 CONG. REC. S20-41-42 (daily ed. Feb. 2, 1995) (statement of Sen. Murkowski); U.S. GEN. ACCOUNTING OFFICE REGULATORY REFORM: INFORMATION ON COSTS, COST-EFFECTIVENESS, AND MANDATED DEADLINES FOR REGULATIONS 24, 49 (1995).

Morrall's table also makes regular appearances in the Office of Management and Budget's annual reports on federal regulation. See, e.g. OFFICE OF MANAGEMENT AND BUDGET. REGULATORY PRocraM OF THE UNITED STATES GOVERNMENT, APRIL 1. 1991-MARCH 31, 1992 at 12 tbl.2 (1991) (hereinafter 
Despite the pervasive reliance on Morrall's table in scholarly and political discussion of risk regulation, no one has determined-or even asked-whether the fantastic costs reported by Morrall are open to question. In this Article, I fill this gap. I argue that John Morrall's table is in the nature of a modern urban legend, a vivid, plausible, "false-true tale," circulated broadly, embellished with local detail, and believed implicitly. ${ }^{4}$ Like other modern legends, such as stories about rats served as hamburger and alligators living in the sewers, John Morrall's story is strange and believable. It reflects the "hopes, fears, and anxieties" of modern life. ${ }^{5}$ And it is false-true.

Indeed, as I explain, there is ample room for disagreement with the picture of the regulatory system drawn by Morrall. For starters, a large percentage of the regulations appearing at the bottom of Morrall's list-the allegedly costliest regulations-have never taken effect. Many of these rules were rejected precisely because the agencies in question determined that their benefits did not justify their costs; at least by the regulatory reformers' lights, then, these regulatory decisions should be counted as successes. By topsy-turvy logic, however, they have become known as regulation's greatest failures.

Equally striking is the disparity between the agencies' (often implicit) estimates of costs per life saved and Morrall's estimates of such costs. Morrall's estimates are inevitably higher than the agencies' implicit estimates, sometimes as much as 1000 times higher. These huge disparities appear to arise mostly from two adjustments Morrall made to the agencies' estimates of regulatory benefits. First, in some cases, Morrall rejected the agencies' estimates of risk and relied instead upon what he regarded as more reliable -and inevitably lower-estimates. ${ }^{6}$ Use of lower estimates of risk led to lower estimates of lives saved, which led to higher costs per life saved. Second, in all cases, Morrall applied a technique that has come to be known as "discounting lives": He reduced the estimates of the number of lives that would actually be saved by a regulation in the future by ten percent for every year expected to pass before the lives were saved.? For example, whereas Morrall estimated that the Occupational Safety and Health Administration (OSHA) rule limiting arsenic exposures in the workplace ${ }^{8}$ would actually save 11.7 lives per year, ${ }^{9}$ this estimate of lives saved dropped to approximately

1991-1992 OMB REPORT]; OFFICE OF MANAGEMENT AND BudGet, Regulatory PROGRAM of THE UNITED STATES GOVERNMENT, APRIL 1, 1987-MARCH 31, 1988, at xx (1987) (hereinafter 1987-1988 OMB REPORT].

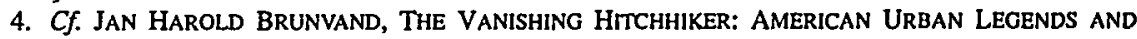
THEIR MEANINGS at xiii (1981).

5. Id. at 2 .

6. See Morrall, supra note 1 , at 28 .

7. See id.

8. See Occupational Exposure to Inorganic Arsenic, 43 Fed. Reg. 19,584 (1978) (to be codified at 29 C.F.R. pt. 1910).

9. See Morrall, supra note 1, at 30 tbl.4. 
0.35 lives per year after discounting. ${ }^{10}$ By deflating the estimates of lives saved, discounting greatly inflated the costs per life saved of the rules that were designed to protect against the risks of long-latency diseases and longterm ecological harm. Again, these are the rules that appear at the bottom of Morrall's list.

Without these adjustments to the agencies' estimates of regulatory benefits, the costs per life saved of all but two of the regulations on Morrall's list fall to less than $\$ 5$ million." This cost compares favorably to current estimates of the monetary value of a human life, based on the wage premiums reportedly accepted by workers in risky occupations: Studies commonly cite a range of $\$ 3$ million to $\$ 7$ million for the value of a statistical life. ${ }^{12}$ Thus, even if one accepted the rather stringent and controversial condition that market exchanges are the appropriate measure of the value of a human life, one would be inclined to conclude that the costs per life saved of the regulations on Morrall's list-as calculated based on the agencies' estimates of regulatory benefits-fall well within the bounds of reasonableness.

Moreover, even these lower costs are inflated insofar as they reflect only one regulatory benefit: the prevention of quantified cases of human sickness and death. In practice, this means that the only regulatory benefit captured by Morrall's table, and by my own figures based on the agencies' calculations, is the prevention of premature human death from cancer. Yet, as we shall see, the regulatory programs that fare poorly in Morrall's table do not just prevent cancer. They prevent many human illnesses that cannot be quantified; they prevent ecological harm; and they prevent harms to values that are widely shared, such as autonomy, community, and equity. Described in this light, most of the regulatory programs at the bottom of Morrall's list are not just-barely cost-justified, they are bargains.

One will want to know whose vision of the costs and benefits of the regulatory system-Morrall's or mine-is correct. As I explain, however, one cannot choose between these very different pictures of the regulatory system without first making important and contested choices about values. The decision whether to discount lives saved in the future, which explains so much of the difference between Morrall's numbers and my own, ultimately turns on one's views of the worth of lives saved today relative to lives saved tomorrow.

10. The estimate of 0.35 lives saved after discounting is based on the following calculations. OSHA estimated that the annualized costs of this rule would be approximately $\$ 32$ million. See Occupational Exposure to Inorganic Arsenic, 43 Fed. Reg. at 19.606. Dividing this cost by Morrall's estumate of 11.7 annual lives saved, see Morrall, supra note 1, at 30 tbl.4, leads to a cost per life saved without discounung of approximately $\$ 2.7$ million. The ratio of the cost without discounting ( $\$ 2.7$ mullion) to the cost after discounting ( $\$ 92.5$ million, see id.) is 0.02918 . Rounding this rato to 0.03 and applyung th to the nodiscounting estimate of 11.7 annual lives saved yields an after-discounting estimate of approxımately 0.35 annual lives saved.

11. See infra note 392 and accompanying text.

12. See, e.g., VISCUSI, supra note 2, at 51-74: Viscusi, supra note 2, at 1431. 
Even the assessment of physical risk reflects choices about values. The decisions whether, for example, to credit the results of studies showing heightened risks in laboratory animals and whether to fix attention on the highest plausible estimates of risk turn on one's view of the proper response to scientific uncertainty. Finally, the very decision to report the costeffectiveness of federal regulation as a function of costs per quantified human life saved presupposes a particular, and particularly narrow, vision of the purposes of risk regulation. Value choices of this kind underlie Morrall's numbers, as well as my own. To say that one of these sets of numbers is true, and the other false, is thus misleading. It depends on one's hopes, fears, and anxieties.

After examining the values inherent in Morrall's figures, I discuss the lessons that might be learned from the wide and uncritical embrace that Morrall's table has received in the literature on risk regulation. Certainly, many who have relied on Morrall's figures share the values implicit in those figures and would not be displeased to learn that the figures embody those values. But this is by no means universally true. Indeed, some of the same authors who have relied on Morrall's numbers in concluding that the current regulatory system needs repair have also argued (sometimes in the very same articles) against the basic assumptions underlying Morrall's numbers. Why then has no one before now questioned the basis for the breathtaking costs Morrall cites? I suggest that the widespread acceptance of Morrall's table shows the perils of precise quantification. A table like Morrall's, with its estimates to the third decimal point, has the appearance of objective fact. In reality, however, Morrall's table is like a deep well into which all of the most prominent criticisms of the current regulatory state have been poured. It is not surprising that those criticisms may, in turn, be drawn back out of the well. But this tells us nothing we did not know before the table was prepared.

\section{THE STANDARD ACCOUNT}

The last two decades have witnessed unprecedented attention to the costs and benefits of the regulatory state. Regulations designed to reduce risks to human health have received particularly close scrutiny. Nevertheless, one can find few efforts to discover how well the system for regulating risk generally performs. Certainly, there have been numerous studies of the costs and benefits of specific regulations ${ }^{13}$ as well as many broad-gauged critiques of the inefficient tendencies of particular categories of regulation, such as technology-

13. See, e.g., John F. Morrall III, Cotton Dust: An Economist's View, in THE ScIENTIFIC BASIS of HEALTH AND SAFETY REgulation 93 (Robert W. Crandall \& Lester B. Lave eds., 1981). 
based regulation. ${ }^{14}$ Yet very little empirical evidence exists regarding the costs and benefits of the risk-regulating system as a whole. ${ }^{15}$

In 1986, an economist at the Office of Management and Budget (OMB) named John Morrall attempted to fill this gap. Noting that "there is little systematic information describing the kinds of risks the government has chosen to regulate or the effectiveness of these interventions," Morrall set out to study the cost-effectiveness of federal regulations designed to reduce risks of premature human death. He chose forty-four regulations in all, based on the availability of "reasonably complete information" on costs and benefits. ${ }^{17}$ The centerpiece of Morrall's article is a table showing the cost per life saved of these forty-four regulations. ${ }^{18}$ Morrall's table, which is reproduced below as Table 1, shows a stunning variation in costs per life saved: Costs range from as low as $\$ 100,000$ per life saved (the cost of the 1967 regulation by the National Highway Traffic Safety Administration (NHTSA) of steering columns ${ }^{19}$ ) to as high as $\$ 72$ billion per life saved (the cost of OSHA's 1985 regulation of formaldehyde ${ }^{20}$ ).

Discerning the full impact of this dramatic table on the debate over risk regulation is complicated by the existence of several different versions of it, some of which do not bear a citation to Morrall's original work. Nevertheless, close examination of the relevant literature reveals that the table, and close variants of it, have been used to suppor every one of the most prominent proposals for regulatory reform to have emerged from the academy or Congress in the last several years. Indeed, it is scarcely an exaggeration to say that if you hear a scholar or politician talking about the tremendous disparities in costs per life saved among federal regulatory programs, you can be sure she is-whether she knows it or not-talking about Morrall's table.

14. See, e.g., Bruce A. Ackerman \& Richard B. Stewar, Reforming Environmental Law. 37 STAN. L. REV. 1333 (1985) [hereinafter Ackerman \& Stewar, Reforming Environmental Law]: Bruce A. Ackerman \& Richard B. Stewan, Reforming Environmental Law: The Democratic Case for Mlarket Incentuves, 13 COLUM. J. ENVTL. L. 171 (1988) [hereinafier Ackerman \& Stewan. Reforming Environmental Law: The Democratic Case].

15. For notable recent exceptions, see Draft Repon to Congress on the Costs and Benefits of Federal Regulations, 62 Fed. Reg. 39,352 (Office of Management \& Budget 1997): and Robert W. Hahn \& John A. Hird, The Costs and Benefits of Regulation, 8 YALE J. ON REG. 233 (1991).

16. Morrall, supra note 1 , at 25 .

17. Id. at 27.

18. See id. at 30 tbl.4.

19. See Initial Federal Motor Vehicle Safety Standards. 32 Fed. Reg. 2408, 2414-15 (1967) (to be codified at 49 C.F.R. pt. 571).

20. See Occupational Exposure to Fomaldehyde. 50 Fed. Reg. S0,412 (1985) (to be codified at 29 C.F.R. pt. 1910) (proposed Dec. 10, 1985). 
TABLE 1. The COSTS OF VARIOUS RISK-REducing Regulations PER LIFE SAVED ${ }^{21}$

\begin{tabular}{|c|c|c|c|c|}
\hline REGULATION & STATUS ${ }^{2}$ & $\begin{array}{l}\text { INITIAL } \\
\text { ANNUAL } \\
\text { RISK }^{23}\end{array}$ & $\begin{array}{l}\text { ANNUAL } \\
\text { LIVES } \\
\text { SAVED }\end{array}$ & $\begin{array}{l}\text { COSTS FER LIFE } \\
\text { SAVED } \\
\text { (THOUSANDS) }\end{array}$ \\
\hline Steering Column Protection (NHTSA 1967) & F & 7.7 in $10^{5}$ & 1300.000 & $\$ 100$ \\
\hline Unvented Space Heaters (CPSC 1980) & $\mathbf{F}$ & 2.7 in $10^{5}$ & 63.000 & 100 \\
\hline Oil \& Gas Well Service (OSHA 1983) & $\mathbf{P}$ & 1.1 in $10^{3}$ & 50.000 & 100 \\
\hline Cabin Fire Protection (FAA 1985) & $\mathbf{F}$ & 6.5 in $10^{3}$ & 15.000 & 200 \\
\hline Passive Restraints/Belts (NHTSA 1984) & $\mathbf{F}$ & 9.1 in $10^{5}$ & 1850.000 & 300 \\
\hline Fuel System Integrity (NHTSA 1975) & $\mathbf{F}$ & 4.9 in $10^{6}$ & 400.000 & 300 \\
\hline Trihalomethanes (EPA 1979) & $\mathbf{F}$ & 6.0 in $10^{\circ}$ & 322.000 & 300 \\
\hline Underground Construction (OSHA 1983) & $\mathbf{P}$ & 1.6 in $10^{3}$ & 8.100 & 300 \\
\hline Alcohol \& Drug Control (FRA 1985) & $\mathbf{F}$ & 1.8 in $10^{6}$ & 4.200 & 500 \\
\hline Servicing Wheel Rims (OSHA 1984) & $\mathbf{F}$ & 1.4 in $10^{5}$ & 2.300 & 500 \\
\hline Seat Cushion Flammability (FAA 1984) & $\mathbf{F}$ & 1.6 in $10^{7}$ & 37.000 & 600 \\
\hline Floor Emergency Lighting (FAA 1984) & $\mathbf{F}$ & 2.2 in $10^{2}$ & 5.000 & 700 \\
\hline Crane Suspended Personnel Platform (OSHA 1984) & $\mathbf{P}$ & 1.8 in $10^{3}$ & 5.000 & 900 \\
\hline Children's Sleepwear Flammability (CPSC 1973) & $\mathbf{F}$ & 2.4 in $10^{4}$ & 106.000 & 1300 \\
\hline Side Doors (NHTSA 1970) & $\mathbf{F}$ & 3.6 in $10^{3}$ & 480.000 & 1300 \\
\hline Concrete \& Masonry Construction (OSHA 1985) & $\mathbf{P}$ & 1.4 in $10^{x}$ & 6.500 & 1400 \\
\hline Hazard Communication (OSHA 1983) & $\mathbf{F}$ & 4.0 in $10^{5}$ & 200.000 & 1800 \\
\hline Grain Dust (OSHA 1984) & $\mathbf{P}$ & 2.1 in $10^{4}$ & 4.000 & 2800 \\
\hline Benzene/Fugitive Emissions (EPA 1984) & $\mathbf{F}$ & 2.1 in $10^{\circ}$ & 0.310 & 2800 \\
\hline Radionuclides/Uranium Mines (EPA 1984) & $\mathbf{F}$ & 1.4 in $10^{4}$ & 1.100 & 6900 \\
\hline Asbesios (OSHA 1972) & $\mathbf{F}$ & 3.9 in $10^{4}$ & 396.000 & 7400 \\
\hline Benzene (OSHA 1985) & $\mathbf{P}$ & 8.8 in $10^{4}$ & 3.800 & 17,100 \\
\hline Arsenic/Glass Plant (EPA 1986) & $\mathbf{F}$ & 8.0 in $10^{4}$ & 0.110 & 19,200 \\
\hline
\end{tabular}

21. This table is a reproduction of Morrall's. See Morrall, supra note 1, at 30 tbl.4.

22. $\mathrm{F}=$ Final; $\mathbf{P}=$ Proposed; $\mathbf{R}=$ Rejected.

23. Annual deaths per exposed population. 


\begin{tabular}{|c|c|c|c|c|}
\hline Ethylene Oxide (OSHA 1984) & F & 44 in $10^{\circ}$ & 2800 & 25.600 \\
\hline Arsenic/Copper Smelter (EPA 1986) & F & 9.0 เn $10^{4}$ & 0.060 & 26.500 \\
\hline Uranium Mill Tailings/Inactive (EPA 1983) & $\mathrm{F}$ & $4.3 \mathrm{in} 10^{4}$ & 2100 & 27.600 \\
\hline Acrylonitrile (OSHA 1978) & $\mathbf{F}$ & 94 in $10^{4}$ & 6.900 & 37.600 \\
\hline Uranium Mill Tailings/Aclive (EPA 1983) & $\mathrm{F}$ & $4.3 \mathrm{in} 10^{4}$ & 2100 & 53.000 \\
\hline Coke Ovens (OSHA 1976) & $\mathrm{F}$ & 1.6 in $10^{4}$ & 31.000 & 61.800 \\
\hline Asbestos (OSHA 1986) & $\mathrm{F}$ & 6.7 in $10^{\circ}$ & 74700 & 89.300 \\
\hline Arsenic (OSHA 1978) & F & $1.8 \mathrm{in} 10^{\circ}$ & 11700 & 92.500 \\
\hline Asbestos (EPA 1986) & $P$ & 29 in $10^{\circ}$ & 10.000 & 104.200 \\
\hline DES (Cartlefeed) (FDA 1979) & $\mathbf{F}$ & 31 in $10^{\prime}$ & 68.000 & 132.000 \\
\hline Arsenic/Glass Manufacturing (EPA 1986) & $\mathbf{R}$ & $3.8 \mathrm{in} 10^{3}$ & 0.250 & 142.000 \\
\hline Benzene/Storage (EPA 1984) & $R$ & 6.0 in $10^{2}$ & 0.043 & 202.000 \\
\hline Radionuclides/DOE Facilities (EPA 1984) & $\mathbf{R}$ & 4.3 in $10^{*}$ & 0.001 & 210.000 \\
\hline Radionuclides/Elemental Phosphorous (EPA 1984) & $\mathbf{R}$ & 1.4 in $10^{\circ}$ & 0.046 & 270.000 \\
\hline Acrylonitrile (OSHA 1978) & $\mathbf{R}$ & 9.4 in $10^{4}$ & 0600 & 308.000 \\
\hline Benzene/Ethylbenzenol Styrene (EPA 1984) & $\mathbf{R}$ & $2.0 \mathrm{in} 10^{\circ}$ & 0.006 & 483.000 \\
\hline Arsenic/Low-Arsenic Copper (EPA 1986) & $\mathbf{R}$ & 2.6 in $10^{4}$ & 0.090 & 764.000 \\
\hline Benzene/Maleic Anhydride (EPA 1984) & $\mathbf{R}$ & 11 in $10^{*}$ & 0.029 & 820.000 \\
\hline Land Disposal (EPA I986) & $\mathbf{P}$ & 2.3 in $10^{4}$ & 2520 & 3500.000 \\
\hline EDB (OSHA 1983) & $\mathbf{P}$ & 2.5 in $10^{4}$ & 0.002 & IS.600.000 \\
\hline Fomaldehyde (OSHA 1985) & $\mathbf{P}$ & 68 in $10^{7}$ & 0.010 & 72.000 .000 \\
\hline
\end{tabular}

\section{A. The Table}

In the 1986 article unveiling his now-famous table on regulatory costs, John Morrall sets the stage by placing in perspective the risks addressed by the regulations he studied. The annual overall risk of dying for the average American is, he informs us, 9 in $1000 .^{24}$ That is, approximately one in every 100 Americans dies each year. Morrall breaks this figure down even further, providing the annual risk we each face of dying in a specific way. We each face, for example, a 1-in-10,000 risk of being murdered; ${ }^{25}$ a 5 -in-10,000,000

24. See Morrall, supra note 1, at 25.

25. See id. at 26 tbl.l. 
risk of being killed by a lightning bolt; ${ }^{26}$ and a 1.8 -in-1,000 risk of dying from cancer. ${ }^{27}$ This last figure is especially significant because, according to Morrall, the health (as opposed to safety) regulations in his study that have become final are "all" aimed at reducing risks from cancer. ${ }^{28}$ Citing an influential study by epidemiologists Sir Richard Doll and Richard Peto, a study which concluded that occupational and environmental exposures account for only six percent of all cancers, ${ }^{29}$ Morrall asserts that "the most important known causes of cancer seem to be immune, for political or practical reasons, to regulatory control." ${ }^{30}$ The clear implication of Morrall's observations is that even if we were to devote infinite resources to reducing human cancer risks, and even if our efforts were to achieve perfect success, we would nevertheless eliminate only a tiny fraction of the overall risks of dying from cancer. ${ }^{31}$

And, according to Morrall's figures on regulatory costs, we do indeed devote a substantial (even if not infinite) number of resources to reducing the risks of cancer. The least expensive regulations on Morrall's list-safety regulations designed, not to prevent cancer or other illnesses, but to prevent deaths from accidents-cost $\$ 100,000$ per life saved. The further one moves down Morrall's table, the more fantastic the costs become. At the same time, as one moves down the list, the character of the rules begins to change, shifting from safety rules to health rules justified, in quantitative terms, exclusively by their prevention of human cancer. ${ }^{32}$ After the thirtieth regulation on the list, the costs begin to exceed $\$ 100$ million for every life saved. The last three regulations on the list each cost more than $\$ 1$ billion per life saved. Even the most ardent defender of the current regulatory system must wince at such numbers.

What is the basis for these numbers? Morrall provides some explanation of the method he used to arrive at them. In estimating compliance costs, Morrall reports that he "generally" accepted agencies' estimates "without

26. See id.

27. See id.

28. Id. at 32 .

29. See Richard Doll \& Richard Peto, The Causes of Cancer: Quantitative Estimates of Avoidable Risks of Cancer in the United States Today, 66 J. NAT'L CANCER INST. 1191, 1256 tbl.20 (1981).

30. Morrall, supra note 1, at 26 (citing Doll \& Peto, supra note 29).

31. Cf., e.g., BREYER, supra note 2, at 6-7 (remarking on the small contribution of regulated and "regulatable" activities to the risks from cancer).

32. Of the last 26 regulations on the list, the quantified life-saving benefits of 24 include only cancer cases avoided. The exceptions are EPA's land disposal rule, see Hazardous Waste Management System: Land Disposal Restrictions, 51 Fed. Reg. 44,714, 44,737 (1986) (to be codified at 40 C.F.R. pts. 260-62, 264-65, 268, 270-71) (proposed Dec. 11, 1986), and OSHA's benzene rule, see Occupational Exposure to Benzene, 50 Fed. Reg. 50,512, 50,541 (1985) (to be codified at 29 C.F.R. pt. 1910) (proposed Dec. 10, 1985). Of these 26 regulations, only one-EPA's benzene/fugitive emissions rule, see National Emission Standards for Hazardous Air Pollutants; Benzene Equipment Leaks (Fugitive Emission Sources), 49 Fed. Reg. 23,498 (1984) (to be codified at 40 C.F.R. pt. 61)-has escaped the charge that its costs exceed its benefits. See, e.g., Lutter \& Morrall, supra note 2, at 59 tbl.6. 
adjustment." $33 \mathrm{He}$ explains that although agencies have an incentive to underestimate costs, this underestimation may be offset by the fact that firms often come up with unexpected ways to reduce the costs of compliance. ${ }^{34}$

In estimating the benefits of regulation, however, Morrall did not adopt the agencies' estimates. Instead, he made two significant adjustments to these estimates in developing his table. First, Morrall adjusted the agencies' estimates of future costs and benefits-including the number of lives saved by regulation-by applying a ten percent discount rate to them. ${ }^{35}$ This discount rate was in line with the guidelines then used by the OMB in performing costbenefit analysis. ${ }^{36}$ In explaining his decision to discount future lives saved, Morrall asserts that his judgment on this point is "impeccable" because one would otherwise have to conclude that a regulation saving 100 lives a decade from now is better than a regulation saving ninety-nine lives today and that "all rules yielding continuous benefits are worth any amount of immediate costs." 37 As I have mentioned, discounting can have a large effect on estimates of future benefits. ${ }^{38}$ It is important to realize, however, that the column on Morrall's table that reports annual lives saved does not reflect discounting; discounting is instead reflected (implicitly) only in the derivation of the costs per life saved, reported in the last column of the table. ${ }^{39}$

Second, Morrall adjusted the agencies' estimates of the number of lives saved through regulation by relying on different-and lower-estimates of risk and regulatory effectiveness than those provided by the agencies. ${ }^{+0}$ For safety regulations, Morrall "often" reduced agency assumptions about the efficacy of regulation "from 100-percent effectiveness to a more reasonable figure such as 50 percent." 41 For health regulations, where the agency relied on the highest estimate in a range of risk estimates, Morrall sometimes picked an intermediate estimate supplied by the agency. ${ }^{42}$ In other cases, he selected what appeared

33. Morrall, supra note 1, at 29. Although Morrall says that he only "generally"-rather than "always"-accepted the agencies' estimates of costs. I assume throughout this discussion that he accepted those estimates without adjustment in all cases since he provides no example to the contrary.

34. See id.

35. See id. at 28.

36. See Office of Management \& Budget, Executive Office of the Presidest, CirCllar A-94, at 4 (1972).

37. Morrall, supra note 1 , at 28.

38. See supra notes 7-12 and accompanying text.

39. Telephone Interview with John F. Morrall IIl. Chicf. Human Resources and Housing Branch. Office of Information and Regulatory Affairs, Office of Management and Budget (Dec. 18. 1996); see supra Table 1 .

40. In addition, where regulations would prevent nonfatal injuries and/or properny damage. Mormall subtracted monetary benefits from costs and also translated the avoidance of nonfatal injunes into additional lives saved. He reports that he did the latter by assuming, based on studies of individuals' wallingness to pay to avoid health risks, that 50 nonfatal hospitalizations or two permanent disabilutues were equivalent to one death. See Morrall, supra note 1, at 28.

41. Id. at 29.

42. See id. at 28. 
to him to be "the most reliable" estimate of risk, ${ }^{43}$ provided in some cases by "published studies that appeared to reflect prevailing scientific views more accurately than the agency estimate." ${ }^{34} \mathrm{He}$ specifically notes that he rejected OSHA's estimate of the risks of ethylene oxide and instead used the estimate of the Environmental Protection Agency (EPA) because EPA purportedly had relied on epidemiological rather than animal studies. ${ }^{45}$ Beyond this example, Morrall does not elaborate on the specific adjustments he made to the agencies' estimates of cancer risk, nor does he elaborate on his specific reasons for making those adjustments.

In spite of these downward adjustments, Morrall believes that his estimates of the variance in cost-effectiveness between health and safety rules "are probably understated by a large margin" because cancer risks "are routinely overestimated by federal agencies" whereas "safety risks ... a are less likely to be overestimated because of the greater availability of hard data." he asserts that since cancer strikes mostly in old age whereas occupational accidents befall a younger group, estimates of cost-effectiveness based purely on premature mortality-and not on costs "per year of life saved"47 - will understate the differences in cost-effectiveness between health and safety rules. Finally, Morrall notes that his estimates of cost-effectiveness are probably overstated because he generally relies on average rather than marginal costs. ${ }^{48}$

Morrall draws four main lessons from his figures regarding costs per life saved. First, he concludes that the most important determinant of costeffectiveness is the legal status of the regulation in question: "The average and median of cost-per-life-saved estimates for the 26 final rules are $\$ 23$ million and $\$ 2$ million, respectively, compared to $\$ 400$ million and $\$ 289$ million, respectively, for the eight rejected rules." ${ }^{\text {(49 }}$ Morrall speculates that this might mean that "very low benefits or high costs is one factor that may lead to the rejection of a regulatory proposal," but he says that "it is not possible to infer from the data how important this consideration is or what role it plays in rules that are eventually adopted." 50 Second, he contends that safety regulation, aimed at reducing risks from accidents, is much more cost-effective than health regulation, aimed entirely (he says) at reducing risks from cancer. ${ }^{51}$ Indeed, he contends that if we had $\$ 1$ billion to spend on risk reduction, we could save either 2000 lives through safety regulation or twenty-seven lives through

\footnotetext{
43. Id.

44. Id. at 29.

45. See id.; see also infra Subsection II.B.2.e.

46. Morrall, supra note 1 , at 32 .

47. Id.

48. See id. at 31.

49. Id.

50. Id.

51. See id. at 32.
} 
regulation of cancer risks. ${ }^{52}$ Third, Morrall suggests that the numbers in his table provide some evidence that President Reagan's Executive Order No. $12,291^{53}$ — which required cost-benefit analysis for major federal regulations-had provided a measure of regulatory reform, insofar as regulations enacted after the issuance of this executive order had one-third the statistical variance (in terms of costs per life saved) of previous regulations."

Finally, Morrall concludes his article by arguing that, based on the amount of money workers are allegedly willing to accept in return for a slightly increased risk of death on the job, roughly half of the regulations on his list would fail a cost-benefit test. ${ }^{55}$ Although he concedes that a plausible argument could be made on behalf of, say, EPA's 1984 regulation of radionuclide emissions from uranium mines ${ }^{56}$ (which cost $\$ 6.9$ million per life saved ${ }^{57}$ ) or OSHA's 1972 rule on asbestos ${ }^{58}$ ( $\$ 7.4$ million per life saved $^{59}$ ), Morrall would draw the line at EPA's 1986 regulation of arsenic plants $^{60}$ (\$19.2 million per life saved $\left.{ }^{61}\right)$. Once that level of costs is reached, Morrall believes, "it is very likely that resources are being wasted and better life saving strategies are being foregone." ${ }^{62}$

\section{B. The Table's Influence}

Many scholars of the regulatory process share Morrall's concerns. Economists and legal scholars, for example, have lambasted the prohibition against the consideration of costs that is embodied in many environmental laws. ${ }^{63}$ They have criticized the basic mechanism of implementing

52. See id.

53. 3 C.F.R. 127 (1981), revoked by Exec. Order No. 12,866. 3 C.F.R. 638 (1993), repnnted in 5 U.S.C. \$ 601 app. at 557-61 (1994). For a thoughtful crituque of regulatory review under Executuve Order No. 12,29I, see E. Donald Elliot, TQM-ing OMB: Or Why Regulatony Revtew Under Executve Order 12,29I Works Poorly and What President Clinton Should Do About II. LAw \& CoNTENP Pross. Spnng 1994, at 167. In 1993, President Clinton replaced Reagan's order with Executuve Order No. 12.866, which also requires cost-benefit analysis. See Exec. Order No. 12.866, 3 C.F.R. 638. On Execuuve Order No. 12,866 generally, see Richard H. Pildes \& Cass R. Sunstein, Reinventing the Regulaton Stute. 62 U. CuI

L. REV. 1 (1995).

54. See Morrall, supra note 1 , at 34 .

55. See id.

56. See National Emission Standards for Hazardous Air Pollutants: Regulation of Radionuclides. 49 Fed. Reg. 43,906 (1984) (to be codified at 40 C.F.R. pt. 61).

57. See Morrall, supra note 1 , at 30.

58. See Standard for Exposure to Asbestos Dust. 37 Fed. Reg. 11.318 (1972) (to be codified at 29 C.F.R. pt. 1910).

59. See Morrall, supra note 1 , at 30.

60. See National Emission Standards for Hazardous Aur Pollutants: Standards for Inorganic Arsenic.

51 Fed. Reg. 27,956 (1986) (to be codified at 40 C.F.R. pt. 61).

61. See Morrall, supra note 1 , at 34.

62. Id.

63. See, e.g., John P. Dwyer, The Pathology of Symbolic Legislanon. 17 EcolocY L.Q. 233 (1990). Various environmental laws have been interpreted to preclude the consideration of costs. See. e.g. TVA v. Hill, 437 U.S. 153, 173-74 (1978) (holding that, once a federal action is found to jeopardize an endangered species in violation of the Endangered Species Act of 1973, cours may not balance costs and 
environmental and workplace safety regulation-technology-based standards or, more pejoratively, "command-and-control" regulation-as cost-ineffective and have offered as an alternative market-based measures such as pollution taxes and emission trading schemes. ${ }^{64}$ They have charged that agencies' methods for assessing cancer risks overestimate the risks posed to human health by chemicals and other substances, ${ }^{65}$ and have concluded that this overestimation causes agencies to devote too many resources to addressing trivial risks. ${ }^{66} \mathrm{EPA}$ itself has begun to worry that it is paying too much attention to small risks and too little attention to large ones and has suggested that a rearrangement of its regulatory priorities may be in order. ${ }^{67}$

These somewhat arcane topics recently surfaced in political circles when the 104th Congress considered the legislative package accompanying the Contract with America. ${ }^{68}$ Among other things, this cluster of bills would have required that health and safety regulations pass cost-benefit analysis, ${ }^{69}$ that agencies implement the most cost-effective means of regulating risk, ${ }^{70}$ and that quantitative risk assessment-peer-reviewed and subject to judicial review-be the basis for health and safety regulations. ${ }^{71}$

Morrall's table has become Exhibit $\mathrm{A}$ in the academic and political case for regulatory reform. Indeed, one rarely finds an article critiquing the current system that does not at least refer to Morrall's original table or a close variant of it, if not reproduce it in full. ${ }^{72}$ The table has been relied on to argue that

benefits in deciding whether to enjoin the federal action); Natural Resources Defense Council v. EPA, 824 F.2d 1146, 1165 (D.C. Cir. 1987) (holding that EPA may not consider costs in determining the level of acceptable risk for hazardous air pollutants under the Clean Air Act); Lead Indus. Ass'n v. EPA, 647 F.2d 1130, 1150 (D.C. Cir. 1980) (holding that EPA may not consider costs in setting National Ambient Air Quality Standards under the Clean Air Act); Hercules, Inc. v. EPA, 598 F.2d 91, 111-12 (D.C. Cir. 1978) (holding that EPA may not consider costs in setting effluent limits for toxic water pollutants under the Clean Water Act).

64. For the classic statements of this argument in the legal literature, see Ackerman \& Stcwart, Reforming Environmental Law, supra note 14; and Ackerman \& Stewart, Reforming Environmental Law: The Democratic Case, supra note 14. For a critique of claims that market-based environmental measures promote democracy as well as efficiency, see Lisa Heinzerling, Selling Pollution, Forcing Democracy, 14 STAN. ENVTL. L.J. 300 (1995).

65. See, e.g., Albert L. Nichols \& Richard J. Zeckhauser, The Perils of Prudence, REculation, Nov.Dec. 1986, at 13.

66. See, e.g., BREYER, supra note 2, at 18-19.

67. See OFFICE OF POLICY ANALYSIS, U.S. ENVTL. PROTECTION AGENCY, UNFINISHED BUSINESS: A Comparative AsSESSMENT OF ENvironmental Problems at xviii-xx (1987).

68. CONTRACT WITH AMERICA, supra note 3.

69. See Risk Assessment and Cost-Benefit Act of 1995, H.R. 1022, 104th Cong.; Job Creation and Wage Enhancement Act of 1995, H.R. 9, 104th Cong. $\$ 324$.

70. See Comprehensive Regulatory Reform Act of 1995, S. 343, 104th Cong. § 2; $c f$. Exec. Order No. $12,866, \S$ l(b)(11), 3 C.F.R. 638,640 (1993), reprinted in 5 U.S.C. $\$ 601$ app. at 558 (1994) ("Each agency shall tailor its regulations to impose the least burden on society ....").

71. See H.R. 1022; H.R. $9 \S 324$. For a cogent critique of the risk assessment bills, see John S. Applegate, A Beginning and Not an End in Itself: The Role of Risk Assessment in Environmental DecisionMaking, 63 U. CIN. L. REV. 1643 (1995). Congress, though, has not lost its appetite for regulatory reform. See, e.g., Regulatory Improvement Act of 1997, S. 981, 105th Cong.

72. For sources relying on one version or another of Morrall's table in critiquing current regulation, see sources cited supra note 2. See also, e.g., International Union, UAW v. Johnson Controls, Inc., 886 F.2d 871, 916-17 n.14 (7th Cir. 1989) (Easterbrook, J., dissenting), rev'd, 499 U.S. 187 (1991); ROBERT 
the costs of many environmental regulations exceed their benefits, ${ }^{73}$ that many regulations are cost-ineffective or that there are cheaper ways of saving human lives, ${ }^{74}$ that expensive regulations endanger human lives by their very expense, ${ }^{75}$ and that government does not set priorities in a rational manner, indeed, that risk regulation is a "crazy quilt." Sometimes the table is relied on to make all of these arguments at once. ${ }^{77}$ Morrall's "widely circulated table"78 has, in short, served as an empirical foundation for every major proposal for wholesale regulatory reform. ${ }^{79}$ It has become a kind of regulatory Rorschach test, capable of eliciting whatever negative view of the risk-regulating system the observer might hold. ${ }^{80}$

Even so, the full influence of Morrall's figures on the debate over regulatory reform would be easy to miss. Morrall's basic 1986 table has occasionally been updated by Morrall and others for use in subsequent articles and documents. ${ }^{81}$ These later versions of the table often have lost track of Morrall's contribution to the regulatory debate. For example, the 1986 table was updated for use in the reports accompanying the federal budget for fiscal year $1992 .^{82}$ This updated version was itself reproduced in a report by the $\mathrm{OMB}$ on the cost-effectiveness of health and safety regulation. ${ }^{83}$ This was

V. Percival et al., ENVIRONMENTAL Regulation 561 fig.4.8 (2d ed. 1996): U S Gev accolitixg OFFICE, supra note 3 , at 25, 49.

73. See, e.g., Viscusi, supra note 2, at 1430-36 (using cost-benefit analysis based on wage premurn studies). For an argument that valuations of life based on individual preferences will likely vary across contexts (and thus some disparities in costs per life saved should not be surpnsing). see Lewis $A$ Komhauser, The Value of Life, 38 CLEV. ST. L. REV. 209 (1990).

74. See, e.g., BREYER, supra note 2, at 22; Arrow el al., supra note 2, at 221: Zeckhauser \& Viscusi. supra note 2, at 559.

75. See, e.g., Viscusi, supra note 2, at 1454.

76. Cass R. Sunstein, Informing America: Risk, Disclosure, and the First Amendment. 20 FLA ST U L. REV. 653, 657 (1993); see also 141 CoNG. REC. S2042 (dally ed. Feb. 2. 1995) (statement of Sen Murkowski) (arguing that regulatory priorities are often products of "overreactuon")

77. See Regulatory Reform Judician Comm. Hearing, supra note 3, at 89 (statement of Cass R Sunstein).

78. Susan Rose-Ackerman, Regulatory Rejorm: Where Are We Going'. 31 WAKE FOREST L. REV S81. 582 (1996).

79. An updated version of Morrall's table figured quite prominently in testimony on regulatory reform bills introduced in the 104th Congress. See sources ciled supra note 3 . Some of these sources cile the version of the table appearing in Lutter \& Morrall, supra note 2, at 59 tbl.6. See, e.g., Joint Hearing. supra note 3, at 39 (statement of Robert W. Hahn).

80. But see Daniel A. Farber, Playing the Baseline: Civil Rights, Envinonmental Law, and Statuton? Interpretation, 91 COLUM. L. REV. 676, 677 n.5 (1991) (reviewing CASS R. SUNSTEIN, AFTER TME RIGITTS REVOLUTION: RECONCEIVING THE REGULATORY STATE (1990)) (arguing that dispanties shown in Sunstein's figures on costs per life saved, see SUNSTEIN, supra, al 239-4l-figures derived in part from Morrall's table-are not paradoxical, as Sunstein suggests, unless it can be shown that government regularly rejects regulations that cost less per life saved).

81. Morrall updated the table for his own use in 1994. See Lutter \& Morrall, supra note 2. at 59 tbl.6 He also appears to have updated the table for use in uthers' work. See. e.g. VISCUst, supra note 2, at 26.t tbl.14-5 (reproducing Morrall's table, as "updated by John F. Morrall III via unpublished communicalion with the author, July 10, 1990"); Viscusi, supra note 2, at 1432.35 tbl.1 (same).

82. See OFfICE OF MANAGEMENT \& BUDGET, BUdGet OF THE UNTTED STATES GOVERNMENT: FISCAL YEAR 1992, at 370 tbl.C-2 (1992) (citing Morrall, supra note 1, and explaining that the table was updated "by the Author, et al.").

83. See 1991-1992 OMB REPORT, supra note 3. at 12 tbl.2. 
also the version upon which then-Judge Breyer relied in his widely read book on risk regulation. ${ }^{84}$ Scholars have, in turn, relied on Breyer's table in arguing against various features of the current regulatory system. ${ }^{85}$ By these third and fourth iterations of Morrall's list, Morrall's contribution was lost altogether.

Here is another example of the same phenomenon: The 1987-1988 version of OMB's annual report, Regulatory Program of the United States Government, ${ }^{86}$ included a shortened version of Morrall's 1986 table with a cite to Morrall; ${ }^{87}$ the OMB report was then cited (without reference to Morrall) in a report on the valuation of human life, prepared by Clayton Gillette and Thomas Hopkins for the Administrative Conference; ${ }^{88}$ and Gillette and Hopkins's report has been cited (again without reference to Morrall) in numerous sources as support for the proposition that costs per life saved vary dramatically among federal regulatory programs. ${ }^{89}$ Examples of this dynamic-first a cite to Morrall, then a cite to the source citing Morrall, and so on until the connection to Morrall is forgotten-could be multiplied. ${ }^{90}$ All of these accounts of regulatory costs derive from the same single source-Morrall's 1986 table-but the debt to Morrall has been obscured. ${ }^{91}$

84. See BREYER, supra note 2, at 24 tbl.5 (reproducing an updated version of Morrall's table, citing as sources OFFICE OF MANAGEMENT \& BUDGET, supra note 82; and 1991-1992 OMB REPORT, supra noto 3 , at 12).

85. See, e.g., Cass R. Sunstein, Conflicting Values in Law, 62 FoRDHAM L. REv. 1661, 1670 n.15 (1994) (citing BREYER, supra note 2).

86. 1987-1988 OMB REPORT, supra note 3.

87. See id. at Xx (citing Morrall, supra note 1). The 1987-1988 report also cites the previous year's report. This latter source contains some numbers identical to those in Morrall's list, which was prepared the same year, and some that are noticeably different. Compare, e.g., OFFICE OF MANAGEMENT \& BUDGBT, REgUlatoRy PROGRAM OF THE UNITED STATES GOVERNMENT, APRIL 1, 1986-MARCH 31, 1987, at xxi tbl.3 (1986) [hereinafter 1986-1987 OMB REPORT] (reporting that OSHA's 1984 ethylene oxide rule cost $\$ 60$ million per life saved), with Morrall, supra note 1, at 30 tbl.4 (reporting that this rule cost $\$ 25.6$ million per life saved).

88. See Gillette \& Hopkins, supra note 2, at 368 n.5 (citing 1987-1988 OMB REPORT, supra note 3).

89. See, e.g., Komhauser, supra note 73, at 211 \& n.9 (citing Gillette \& Hopkins, supra note 2); Daniel A. Farber, Revitalizing Regulation, 91 MICH. L. REv. 1278, 1283 n.17 (1993) (book review) (samc).

90. See, e.g., SUNSTEIN, supra note 80 , at $239-40$ app. B (citing Morrall, supra note 1, at 30 (bl.4); Daniel A. Farber, Risk Regulation in Perspective: Reserve Mining Revisited, 21 ENVTL. L. 1321, 1356 \& n.160 (1991) (citing SUNSTEIN, supra note 80).

91. An earlier table on regulatory costs prepared by Morrall in a 1983 paper coauthored with Iry Broder has also played a large role in the regulatory debate. See Ivy E. Broder \& John F. Morrall III, The Economic Basis for OSHA's and EPA's Generic Carcinogen Regulations, in WHAT ROLE FOR GOVERNMENT? 242, 250 \& tbl.15.2 (Richard J. Zeckhauser \& Derek Leebaert eds., 1983). This earlicr table, which shows the costs per life saved of six OSHA and EPA cancer regulations, was, in a sense, a dress rehearsal for Morrall's more extensive table prepared in 1986: The 1983 table's estimates of the lives saved by the six regulations are in most cases identical to the figures provided for these regulations in 1986. (As I discuss later, however, see infra Table 2, the costs per life saved reported in the 1983 table differ dramatically from the costs per life saved reported in the 1986 table.) With minor adjustments, Broder and Morrall's 1983 table formed the basis for a key table in John Mendeloff's book arguing that Jargely costblind standard-setting at OSHA has produced an unduly low volume of workplace regulation, that is, that overregulation has led to underregulation. See JOHN M. MENDELOFF, THE DILEMMA OF TOXIC SUBSTANCE REGULATION: HOW OVERREGULATION CAUSES UNDERREGULATION AT OSHA 22 tbl.2.1 (1988) (crediting Morrall and Broder's contribution to a table showing the costs per life saved of various OSHA regulations and describing adjustments to their figures). The estimates of costs per life saved that Mendeloff derived from Morrall and Broder's table serve as the empirical foundation for the "overregulation" portion of 
Subsequent versions of Morrall's 1986 table also confuse matters by taking different approaches to updating. Some, but not all, of the updated versions alter the figures on costs to reflect the impact of inflation on compliance costs. ${ }^{92}$ Most updated versions also alter the figures on costs to reflect at least some of the changes in the rules that have occurred subsequent to Morrall's original publication. In particular, where a rule was proposed at the time of the 1986 list but later became final, the updated versions typically refer to the costs of the final rather than the proposed rule. ${ }^{93}$ The updated versions of Morrall's original list also often exclude some of the rules he included though they do not always exclude the same rules. ${ }^{94}$ Sometimes the updated versions

Mendeloff's critique. See id. at 22 tbl.2.1 n.a. Mendeloff's argument has itself played an influentral role in the academic and political debate over risk regulation. See Sidney A. Shapiro \& Thomas O McGanty. Not So Paradoxical: The Rationale for Technology-Based Regulanon, 1991 DUKE LJ 729. 730 (crediung Mendeloff with the first elaboration of the idea that "overregulation produces underregulation." which has since become a standard part of the critique of current regulation): see also Cass $R$. Sunsicin. Administrative Substance, 1991 DUKE L.J. 607. 629 (discussing Mendeloff's cntıque and arguıng that technology-based regulation leads to an "overregulation produces underregulatson" paradox). Morrall's pivotal contribution to Mendeloff's argument has gone largely unnoticed. But see Thomas O. MCGARITY \& Sidney A. Shapiro, Workers at RISK: THe FAILED Promise of the OCCUPATtonal Safety aNd HEALTH ADMINISTRATION 269 (arguing that Mendeloff's figures on regulatory costs are "on the high side" in part due to "Mendeloff's heavy reliance upon cost calculations published in papers by John Momall. the OMB economist who made a career of criticizing OSHA standards"). For a crituque of Mendelofrs cntique. see id. at 267-91.

92. Compare OfFiCE OF MANAGEMENT \& BUDGeT, supra note 82, al 370 tbl.C.2 (showing costs in 1990 dollars), with Viscusi, supra note 2, at 1432-35 tbl.1 (showing costs in 198-4 dollars). The adjustment for inflation has sometimes led to mistakes. Close comparison of Morrall's 1986 list with two different updates to this list-the list used in the budget for fiscal year 1992 and an updated version Momall himself prepared in 1994-reveals, bizarrely, that in some cases the costs of regulation first decreased (between the original list and the 1992 version) and then increased (between the 1992 version and Morrall's 1994 update). Compare, e.g., Morrall, supra note 1, at 30 tbl.4 (reporting that the ban on diethylstılbestrol (DES) in cattlefeed cost $\$ 132$ million in 1984 dollars), with OFFCE OF MANAGENENT \& BUDCET, supra note 82, at 370 tbl.C-2 (reporting the cost as $\$ 124.8$ million in 1990 dollars), and Lutter \& Morrall. supru note 2. at 59 (reporting the cost as $\$ 178$ million in 1992 dollars). Morrall reports that such differences are due to mistakes in adjusting for inflation in the 1992 budget's version of the table. and he advises agasnst using this version. Telephone Interview with John F. Morrall III, supra note 39. This is the verston. however. used by then-Judge Breyer, see, e.g., BREYER, supro note 2. at 24-27 tbl.5. and, occasionally, by Professor Sunstein, see, e.g., SUNSTEIN, supra note 80, at 239-40 app. B.

93. All of the following sources refer, for example, to the final (as opposed to proposed) versions of OSHA's rules on grain dust, see Grain Handling Facilities, 52 Fod. Reg. 49.592 (1987) (1o be codıfied al 29 C.F.R. pts. 1910, 1917), and benzene, see Occupational Exposure to Benzene, S2 Fed. Reg. 34,460 (1987) (to be codified at 29 C.F.R. pt. 1910)- hough they disagree about how much these rules cost. See OFFCE OF MANAGEMENT \& BUDGET, supra note 82, at 370 tbl.C-2 (stating that, in 1990 dollars. the grain dust rule cost $\$ 2.8$ million per life saved and the benzene rule cost $\$ 8.9$ million): Sunstein. Health-Heallh Tradeoffs, supra note 2, at 1547-48 (stating that, in 1992 dollars, the gran dust rule cost $\$ 8.8$ million and the benzene rule cost $\$ 23.1$ million); Viscusi, supra note 2. at 1432-35 (stating that, in 1984 dollars, the grain dust rule cost $\$ 5.3$ million and the benzene rule cosi $\$ 17.1$ million).

94. See, e.g., OFFICE OF MANAGEMENT \& BUDGET, supra nole 82. al 370 ibl.C-2 (cxcluding 10 rules, including rules regarding benzene air emissions, radionuclide emussions from elemental phosphorous plants and Department of Energy facilities, and arsenic air emissions): Sunsteın. Health-Health Tradeoffs, stupro note 2, at 1547-48 tbl.2 (excluding rules on oil and gas well service, OSHA's 1972 asbestos rulc. EPA's rules regarding arsenic emissions from glass plants and copper smelters, and the rules on land disposal and ethylene dibromide (EDB)); Viscusi, supra note 2. at 1432-35 tbl.1 (cxcluding rules regarding stecnng column protection, fuel system integrity, trihalomethanes, children's slexpware flammabılıty. and side doors: OSHA's 1972 rule on asbestos and its rules on acrylontnle, coke ovens. and arsenic: and the FDA's ban on DES in cattlefeed). 
also add rules-including both rules that were in place at the time of the 1986 list and rules that were subsequently proposed. ${ }^{95}$

Morrall's figures on regulatory costs have thus influenced a wide group in academia and in government, and different versions of his 1986 table have proliferated. There appears, however, to be no systematic rationale at work in choices about altering Morrall's original list; sometimes rules are added or subtracted without apparent logic. Even so, the variations on Morrall's 1986 list differ in detail rather than in overall substance. They contain almost all of the rules Morrall's list contains, and they certainly follow the general thrust of his original table. That is, all of the variations on Morrall's list report that costs per life saved vary strikingly among federal regulatory programs and that these costs quite often reach hundreds of millions, even billions, of dollars. For simplicity's sake, therefore, I use Morrall's 1986 table as the focal point for the discussion that follows. Several of my most pointed criticisms, however, apply more to the uses to which his table has been put than they do to the original table.

\section{TABLE OF LEGENDS}

Despite the widespread reliance on Morrall's 1986 table and its variants, I have not found any source in the literature on risk regulation that analyzes in any detail either the criteria for inclusion of rules on the table or the stunning costs reflected there. Yet, as I explain in this part, the list is both overinclusive and underinclusive in its choice of rules. Moreover, comparison of Morrall's numbers with the agencies' own explanations of their decisions yields surprising results: Morrall's estimates of costs per life saved are far higher-sometimes orders of magnitude higher-than the agencies' estimates of such costs.

I discuss my findings with respect to both the selection of rules and the determination of costs per life saved in some detail for two reasons. First, Morrall's table has led not only to a widespread perception that the costs of life-saving rules are often wildly variant and wildly high but also to a perception that the decisionmaking processes that lead to such rules reflect a mindless fixation on trivial risks. Examination of the actual decisionmaking processes that led to these rules creates a markedly different impression. Second, it is essential that others be able to reproduce-and question-my conclusions about the representativeness and accuracy of the numbers reflected in Morrall's table. Perhaps my most fundamental objection to Morrall's table is that it buries important normative choices in a seemingly objective array of

95. See, e.g., OFFICE OF MANAGEMENT \& BUDGET, supra note 82, at 370 tbl.C-2 (adding 15 rules to the list, ranging in effective date or date of proposal from 1970 to 1991). 
numbers. ${ }^{96}$ By providing merely a summary report of my own conclusions, I would be repeating Morrall's most basic mistake. I would like my own analysis to begin a conversation about the costs and benefits of risk regulation, not end one.

\section{A. Choosing the Rules for the List: Overinclusion and Underinclusion}

John Morrall and many others have used his table to argue that there is something systematically amiss in our system for regulating risk. That is, his table has not been used merely to point out the existence of some regulations that cost too much in relation to the benefits they confer or that cost too much in comparison to alternative ways of regulating risk. His table has been used instead to support wholesale regulatory reform. It is thus important to consider the legal status of the regulations appearing on Morrall's list. If it turns out that the current system for regulating risk managed to reject many of the costliest regulations on the list before they were ever implemented, that result would undermine the argument for wholesale reform; this is particularly true if the very reason for rejection was that the costs of the rules exceeded their benefits. It is also important to know whether the rules on Morrall's list comprise a representative sampling of the products of the current regulatory system. If they do not-and if they systematically err by, for example, excluding rules or rulemaking possibilities that imposed or would have imposed lower costs per life saved-this would also diminish the case for wholesale regulatory reform.

I thus begin this part by discussing the legal status of the rules on Morrall's list. As it turns out, Morrall's table is itself a crazy quilt. A substantial portion of the rules on the list were rejected by the relevant agencies on the very ground that their benefits did not exceed their costs. Although Morrall himself notes that cost-effectiveness was an important determinant of legal status, ${ }^{97}$ he only glancingly acknowledges that a substantial percentage of the rules at the bottom of his list were rejected for a reason he would presumably applaud. ${ }^{98}$ Still more troubling is the omission, in several updated versions of Morrall's list, of any mention of the legal status of the rules on the list; ${ }^{99}$ these versions of the lists imply, incorrectly, that all of the rules on the list are in force and generating current costs. Perhaps most perplexing, however, is that several of the rules on Morrall's list simply do not

96. See infra Part III.

97. See Morrall, supra note 1 , at 33; see also supra text accompanying notes $49-50$

98. See Morrall, supra note 1, at 31 ("Evidently. very low benefits or high costs is one factor that may lead to the rejection of a regulatory proposal, although it is not possible to infer from the data how important this consideration is or what role it plays in rules that are eventually adopted."): $c f$. Viscusi. supra note 2, at 265 (discussing Morrall's list, and noting that "OMB blocked some of the panticularly inefficient regulations").

99. See, e.g., BREYER, supra note 2, at 24-27 tbl.5. 
exist; two never existed, as far as I can tell, and two were proposed but not issued. ${ }^{100}$ Insofar as the list includes rules rejected for the very reason that their costs were deemed unjustified and rules that do not exist, the list is overinclusive. ${ }^{101}$

In addition, although Morrall indicates that his criterion for inclusion of rules on the table was the availability of "reasonably complete information" on costs and benefits, ${ }^{102}$ there are many regulations, and failures to regulate, that fit this criterion but were nevertheless excluded from the list. These regulations imposed, or would have imposed, dramatically lower regulatory costs than many of the rules Morrall did include. In this sense, therefore, the list is underinclusive as well.

\section{Overinclusion: Rules Rejected Because Their Benefits Did Not Exceed Their Costs}

In this subsection, I discuss several rules on Morrall's list that were rejected precisely because their benefits did not exceed their costs. By the regulatory reformers' lights, the rejection of such rules should be viewed as a success story. Nevertheless, these rules appear at the bottom of Morrall's list, a placement that suggests, perversely, that these decisions were among the worst of those he examined.

\section{a. Benzene (EPA 1984)}

In 1977, EPA listed benzene as a hazardous air pollutant under section 112 of the Clean Air Act. ${ }^{103}$ At the time, section 112 required EPA to regulate air pollutants "which may reasonably be anticipated to result in an increase in mortality or an increase in serious irreversible, or incapacitating reversible, illness" and directed the agency, in regulating such pollutants, to "provide an ample margin of safety to protect the public health."104 In 1980, EPA proposed performance-based standards under section 112 for benzene emissions from several categories of sources: benzene storage vessels, ${ }^{105}$

100. See infra Subsection II.A.2.

101. In this section, I generally take Morrall's estimates of risks and costs as given; that is, I assume that the rules I discuss here indeed reflect the costs per life saved that Morrall assigned to them. It is important to realize, however, that the costs per life saved of the nules I discuss here reflect the same significant adjustments that I will discuss with respect to other rules. See infra Section II.B. Morrall's estimates of the costs per life saved of the rejected rules are thus likely overstated by a wide margin as compared to the agencies' estimates.

102. Morrall, supra note 1 , at 27.

103. See National Emission Standards for Hazardous Air Pollutants; Addition of Benzene to List of Hazardous Air Pollutants, 42 Fed. Reg. 29,332 (1977).

104. 42 U.S.C. $\$ 7412$ (a)(1), (b)(1)(B) (1988) (amended 1990).

105. See Benzene Emissions from Benzene Storage Vessels; National Emission Standard for Hazardous Air Pollutants, 45 Fed. Reg. 83,952 (1980) (to be codified at 40 C.F.R. pt. 61) (proposed Dec. 19, 1980). 
ethylbenzene/styrene plants, ${ }^{106}$ and maleic anhydride plants. ${ }^{107}$ In proposing these standards, EPA referred to several different health risks caused by benzene, including leukemia, aplastic anemia, and potentially inheritable chromosomal abnormalities; ${ }^{108}$ the agency, however, quantified only the increased risks of leukemia. ${ }^{109}$

Four years later, after a change of administration, EPA withdrew these proposed standards altogether in a 1984 rulemaking cited in three different places in Morrall's table. In doing so, EPA asserted that

both the benzene health risks (annual leukemia incidence and individual lifetime risk from high exposure) to the public from these source categories and the potential reductions in health risks achievable with available control techniques are too small to warrant Federal regulatory action under section 112 of the Clean Air Act. ${ }^{110}$

The agency's explanation of its decision to withdraw these standards reads like it was written by the regulatory reformers who have relied on Morrall's table. The agency emphasized that, since the time that the standards had been proposed, the source categories in question had reduced their benzene emissions by a larger amount than new control measures could achieve."' Because of these reductions, the remaining risks from these facilities were lower than EPA had originally estimated. ${ }^{112}$ In defending its reliance on the

106. See National Emissions Standards for Hazardous Air Pollutants: Benzene Emissions from Ethylbenzene/Styrene Plants, 45 Fed. Reg. 83,448 (1980) (to be codified at 40 C.F.R. pt. 61) (proposed Dec. 18, 1980).

107. See National Emission Standard for Hazardous Air Pollutants; Benzene Emissions from Maleic Anhydride Plants, 45 Fed. Reg. 26,660 (1980) (10 be codified at 40 C.F.R. pt. 61) (proposed Apr. 18, 1980).

108. See, e.g., Benzene Emissions from Ethylbenzene/Styrene Plants, 45 Fod. Reg. at 83,449 n.2.

109. See, e.g., id. at 83,449-50. EPA also expressed uncertainty about its numerical estimates of risk. The epidemiological studies on which the agency relied, it conceded, contained several difficulties: They involved a "healthy white male cohor of workers" and thus might not accurately have described risks to other subpopulations, such as women, children, people of color, the aged, and the sick; leukemia was the only health effect studied; and the agency's estimates did not take into account the potential for "cumulative or synergistic effects [from] concurrent exposure[s]" to a variety of substances. Id. al 83,450. As the agency noted, these uncertainties could just as well have meant that the agency's cstimates of risk were understated as overstated. See Benzene Emissions from Benzene Storage Vessels, 45 Fed. Reg. at 83,954; Benzene Emissions from Ethylbenzene/Styrene Plants, 45 Fed. Reg. at 83.450. For an extended discussion of the uncertainties in EPA's estimates of risks from benzene and of the policy docisions implicit in its estimates of risk, see Howard Latin, Good Science, Bad Regulation, and Toxic Risk Assessment, 5 YALE J. ON REG. 89 (1988). As for costs, the agency estimated that the industry would likely save moncy as a result of the proposed standards for ethylbenzene/styrene plants because those standards would cause firms either to reduce their benzene requirements due to materials recovery or to reduce their process energy requirements. See Benzene Emissions from Ethylbenzene/Styrene Plants, 45 Fed. Reg. at 83,455.

110. National Emission Standards for Hazardous Air Pollutants; Benzene Emissions from Maleic Anhydride Plants, Ethylbenzene/Styrene Plants, and Benzene Storage Vessels, 49 Fed. Reg. 23.558. 23.558 (1984) (to be codified at 40 C.F.R. pt. 61).

111. See id at 23,562.

112. For EPA's revised estimates of risk, see National Emission Standards for Hazardous Air Pollutants; Benzene Emissions from Maleic Anhydride Plants. Ethylbenzene/Styrene Plants, and Benzene Storage Vessels, 49 Fed. Reg. 8386 (1984) (to be codified at 40 C.F.R. pl. 61). 
quantitative risk assessments showing low risks, the agency rejected arguments that these risk assessments underestimated risks because they did not take account of potentially enhanced risks to vulnerable subgroups or of synergistic effects from chemical mixtures. The agency explained that it had no data permitting the quantification of enhanced risks to vulnerable subgroups or enhanced risks from synergisms. ${ }^{113}$ It conceded, however, that these were "qualitative factors" that could influence (in an unelaborated way) its risk estimates. ${ }^{\text {II }}$

EPA explicitly refused to countenance a regulation justified only by the rationale that the agency "should err on the side of caution" because that principle did not "fully consider the obligation of reasonable accuracy in selecting appropriate test data upon which to estimate impacts." ${ }^{115}$ And, in a comparison that would warm the hearts of many regulatory reformers, the agency explained that it had come to the conclusion that the risks from benzene emissions from the three source categories in question were too small to warrant regulatory action partly by comparing the risks of benzene to the lifetime risks for other environmental hazards such as smoking, drowning, and electrocution. ${ }^{116}$

Given this history, the inclusion of EPA's 1984 decisions on Morrall's list is baffling. Indeed, regulations having the risk and cost profiles cited by Morrall were never even proposed. As I just noted, the emissions from the facilities proposed to be regulated decreased substantially between the EPA's initial proposal to regulate them and its withdrawal of that proposal. EPA announced the lower risk estimates-with their correspondingly higher (implicit) costs per life saved-in 1984, in the course of rejecting the initial proposal. Morrall cites these estimates of risk, not the estimates of risk found at the time of the proposal in 1980, in reporting the risks and costs of these rules. ${ }^{117}$ But the agency never proposed regulating benzene emissions at the risk and cost levels cited by Morrall. The risk estimates cited by Morrall were reported by EPA in the course of withdrawing the proposed standards.

Thus, no person or firm ever spent the $\$ 202$ million, $\$ 483$ million, and $\$ 820$ million per life saved that Morrall reports on his 1986 list, $^{118}$ and no

113. See Benzene Emissions from Maleic Anhydride Plants, Ethylbenzene/Styrene Plants, and Benzene Storage Vessels, 49 Fed. Reg. at 23,561.

114. Id.

115. Id. at 23,563 .

116. See id. at 23,562 .

117. Compare Morrall, supra note 1, at 30 tbl.4 (reporting 0.043 annual lives saved by the benzene/storage rule, 0.006 by the benzene/ethylbenzenol styrene rule, and 0.029 for the benzene/maleic anhydride rule), with Benzene Emissions from Maleic Anhydride Plants, Ethylbenzene/Styrene Plants, and Benzene Storage Vessels, 49 Fed. Reg. at $8389-90$ (reporting excess cancer cases per year of 0.043 from benzene/storage vessels, 0.0057 for ethylbenzenol/styrene process vents, and 0.029 from maleic anhydrido process vents-after taking into account reductions in emissions that had occurred since the time of the proposed rule).

118. See Morrall, supra note 1 , at 30 tbl.4. Although I believe the costs of rules that were never proposed do not belong on Morrall's list, regardless of whether Morrall's figures are accurate or inaccurate. 
government agency ever proposed spending these amounts. (Miraculously, however, in updates to Morrall's list, the costs associated with these long-dead regulations have continued to grow. $)^{119}$ Moreover, these regulations were withdrawn because EPA concluded that the risks they would have regulated were too small to warrant regulatory action; that is, they were withdrawn based on one of the very considerations that Morrall and others have argued should inform regulatory decisions on risk. At least by the regulatory reformers' lights, these regulations deserve a place of honor on any table documenting agency performance. Nevertheless, they are among the ten regulations at the very bottom of Morrall's list. To be sure, by use of the letter " $R$ " in the column designating legal status, Morrall himself noted that these rules had been rejected. ${ }^{120}$ But this is a subtlety that has largely been missed in subsequent uses of the table. ${ }^{121}$ Moreover, the very act of labeling the rules "rejected" implies that rules having these reported risk and cost profiles were at one time proposed. As I have shown, they were not. In sum, therefore, the regulations should not appear on Morrall's table. ${ }^{122}$

it is worth noting the disparity between Morrall's estimates of the costs per life saved of EPA's benzene rules and other economists' estimates of such costs. In 1984, for cxamplc, a study funded in par by EPA concluded that EPA's proposed regulation of benzene emissions from maleic anhydride plants would have cost approximately $\$ 6.5$ million per life saved. See John A. Haigh et al. Benefir.Cost Analysis of Environmental Regulation: Case Studies of Hazandous Air Pollutants, 8 HARV. ENVTL L REV. 395. 408 (1984) (estimating that the rule would save 0.4 lives per year at an annual cost of 52.6 million). In 1986. Morrall reporred that this rule would have cost more than 100 times as much, or $\$ 820$ million per life saved. See Morrall, supra note 1, at 30 tbl.4.

119. See, e.g., Sunstein, Health-Health Tradeoffs, supra note 2. at 1548 tbl.2 (reportung, based on an update to Morrall's 1986 list, that the (rejected) benzene regulations cost \$273 mullion. 5652 mullion. and $\$ 1.1$ billion per life saved, compared to the costs of $\$ 202$ million, $\$ 483$ million, and $\$ 820$ million reported in Morrall's list).

120. See Morrall, supra note 1 , at 30 tbl.4.

121. Indeed, as I have noted, see supra text accompanying note 99 . some subsequent uses of the table omit any reference to legal status whatsoever. See, e.g., BREYER, supra note 2, at 24-27. But see Sunstein, Health-Health Tradeoffs, supra note 2, at 1548.

122. Several years after EPA's 1984 decision to withdraw its proposed benzene rules. the D.C. Circuit cverturned the agency's approach to setting emission standards under section 112 of the Clean Atr Act. See Natural Resources Defense Council v. EPA (Vinyl Chloride), 824 F.2d 1146 (D.C. Cir. 1987) (holding that EPA may not consider costs in determining an acceptable level of risk from hazardous aur pollutants). On a voluntary remand from this decision. EPA again chose not to regulate maleic anhydnde process vents. explaining that benzene was no longer used in the manufacture of maleic anhydride. See Nalional Emission Standards for Hazardous Air Pollutants; Benzene Emissions from Maleic Anhydride Plants, Ethylbenzene/Styrene Plants, Benzene Storage Vessels. Benzene Equipment Leaks, and Coke By-Product Recovery Plants, 54 Fed. Reg. 38,044, 38,046 (1989) (to be codified a! 40 C.F.R. pt. 61). The agency also declined to regulate ethylbenzene/styrene plants, concluding that the existing level of control at these facilities already provided an ample margin of safely. See id. The highest risk from ethyl benzene/styrene process vents, as estimated by the agency, was a risk of about $I$ in 100,000 . faced by about 600 people: this would, the agency observed, amount to approximately one cancer case every 5000 years. See id. The EPA did, however, issue a standard requiring more effective controls for benzene storage vessels. See td. John Graham subsequently estimated this regulation's cost per year of life saved to be $\$ 290,000$. See John D. Graham, The Risk Not Reduced, 3 N.Y.U. ENVTL. LJ. 382. 396 ibl.2 (1994). None of these post-Vinyl Chloride decisions appears in updated versions of Morrall's table. For an argument that the Vinyl Chlonde decision had little practical effect on EPA's substantive requirements under section 112, but rather "effectively forced EPA's policymaking underground," see Dwyer, supra note 63. at 271. 


\section{b. Radionuclides (EPA 1984)}

EPA's regulation of radionuclides also grew out of section 112 of the Clean Air Act. In 1979, EPA listed radionuclides as a hazardous air pollutant under section 112. ${ }^{123}$ In 1983, EPA proposed standards for several categories of sources of radionuclide emissions, including Department of Energy (DOE) facilities ${ }^{124}$ and elemental phosphorus plants. ${ }^{125}$

In 1984, EPA withdrew both of the standards it had proposed the previous year. ${ }^{126}$ In reasoning reminiscent of its withdrawal of the benzene regulations, the agency explained that "current practice provides an ample margin of safety in protecting the public health from the hazards associated with exposure to airborne radionuclides." ${ }^{27}$ In elaborating on its decision, the agency attempted to place the risks from radiation exposure in perspective:

[E]veryone is exposed to background radiation due to cosmic radiation, and radioactivity in minerals, soils, and even our own bodies. Background radiation levels vary across the U.S., but average about 100 [millirem per year] for each person. There is very little that people can do to control exposure to background radiation. Over a lifetime this exposure is estimated to contribute to a fatal cancer risk of about one or two cases for every one thousand people. ${ }^{128}$

Although the agency had slightly increased its estimates of the risks from the relevant facilities since the time of the proposal, ${ }^{129}$ it nevertheless chose to

123. See National Emission Standards for Hazardous Air Pollutants; Addition of Radionuclides to List of Hazardous Air Pollutants, 44 Fed. Reg. 76,738 (1979).

124. See National Emission Standards for Hazardous Air Pollutants; Standards for Radionuclides, 48 Fed. Reg. 15,076 (1983) (to be codified at 40 C.F.R. pt. 61) (proposed Apr. 6, 1983). The agency cstimated that the individual risk of adverse health effects from radionuclides emitted by the DOE-administered facilities with the highest radionuclide emissions (including, for example, sites where nuclear weapons were produced and tested) was less than 2 in 10,000 and that the population risk from these facilities was less than one potential health effect for every 15 years of operation. See id. at 15,080. Morrall's estimate of lives saved is very different: He reports that the proposed rule would have saved one life every 1000 years. See Morrall, supra note 1, at $30 \mathrm{tbl}$.4. For a discussion of the effect of Morrall's lower risk estimates on his estimates of the costs per life saved of the final rules on his list, see infra Subsection II.B.2.

125. See Standards for Radionuclides, 48 Fed. Reg. at 15,084. The agency estimated that the eight elemental phosphorous plants then operating in the United States posed an individual risk of at most 1 in 10,000 to the maximally exposed individual. See id. at 15,084-85. Combined with the agency's population figures, this risk would lead to about one health effect per 20 years of operation of all these facilities or an average of 0.05 health effects per year. See id. at 15,085 . Morrall's estimate is only marginally different. See Morrall, supra note 1, at 30 tbl.4 (estimating that the rulc regarding elemental phosphorous plants would save 0.046 lives per year).

126. See National Emission Standards for Hazardous Air Pollutants; Regulation of Radionuclides, 49 Fed. Reg. 43,906 (1984) (to be codified at 40 C.F.R. pt. 61).

127. Id. at 43,907 .

128. Id. at 43,911 .

129. See id. at 43,911-12 (stating that risks from elemental phosphorous plants lead to approximately one fatal cancer case every 17 years (or an average of 0.058 per year) and risks from DOE facilities lead to approximately one fatal cancer case every 13 years (an average of 0.077 per year)). Morrall's cstimates of 0.046 and 0.001 annual lives saved by the elemental phosphorous and DOE rules, respectively, see Morrall, supra note 1, at 30 tbl.4, are again lower than the agency's. 
withdraw the proposed standards because the aggregate risk to the populations living near these facilities remained low and because the costs of reducing emissions would be high. ${ }^{130}$

The history of these regulations thus reveals, at least from the regulatory reformers' perspective, another story of success rather than failure. Like the withdrawn benzene regulations, the two radionuclide regulations to which Morrall refers were decisions to withdraw regulation rather than to impose it. Moreover, as in the case of the withdrawn benzene regulations, these decisions were made after a balancing of risks and benefits that Morrall and other regulatory reformers would presumably support. Nevertheless, the two withdrawn radionuclide regulations are also among the bottom ten regulations on Morrall's table. ${ }^{131}$

\section{c. Asbestos (EPA 1986)}

In 1986, EPA proposed banning virtually all manufacturing and use of asbestos, ${ }^{132}$ and this ban become final three years later. ${ }^{133}$ The Fifth Circuit invalidated the ban in 1991, largely because the court concluded that the costs of the ban exceeded its benefits. ${ }^{134}$ In my view, EPA's invalidated rule does not belong on updated versions of Morrall's list, even if Morrall himself cannot be faulted for having included the proposed rule back in 1986.

The asbestos ban was EPA's first and (so far) only nationwide ban of a toxic substance under section $6(\mathrm{a})$ of the Toxic Substances Control Act (TSCA), ${ }^{135}$ which allows comprehensive cross-media and cross-industry regulation of toxic pollutants. EPA banned asbestos because it concluded that the ban would save approximately 200 lives that would have otherwise been lost due to cancer over a thirteen-year period, plus an unquantified number of lives that would have otherwise been lost due to cancer in years beyond the study period or due to other illnesses (such as asbestosis) at any time. ${ }^{136}$ The agency estimated that the ban would cost a total of $\$ 450$ million to $\$ 800$

130. See Regulation of Radionuclides, 49 Fed. Reg. at 43.911.

131. The Environmental Defense Fund challenged EPA's decision to withdraw the radionuclide standards. After Natural Resources Defense Council v. EPA (Vinyl Chloride), 824 F.2d 1146 (D.C. Cir. 1987), the court granted EPA's motion for a voluntary remand of the radionuclide emission standards. EPA eventually promulgated standards for radionuclide emissions. See Nationsl Emission Standards for Hazardous Air Pollutants; Radionuclides, 54 Fed. Reg. 51,564 (1989) (to be codified at 40 C.F.R. pt. 61). These new standards do not appear on updated versions of Morrall's list.

132. See Asbestos; Proposed Mining and Import Restrictions and Proposed Manufacturing. Imporation. and Processing Prohibitions, 51 Fed. Reg. 3738 (1986) (to be codified al 40 C.F.R. pt. 763) (proposed Jan. 29, 1986).

133. See Asbestos; Manufacture, Importation, Processing, and Distribution in Commerce Prohibitions. 54 Fed. Reg. 29,460, 29,468 (1989) (to be codified at 40 C.F.R. pt. 763).

134. See Corrosion Proof Fittings v. EPA, 947 F.2d I201 (Sth Cir. 199!).

135. 15 U.S.C. \& 2605(a) (1994).

136. See Asbestos; Manufacture, Importation. Processing, and Distribution in Commerce Prohibitions, 54 Fed. Reg. at $29,468,29,476$. Throughout this discussion, I refer to the cost-benefit profile of the final rule. 
million. ${ }^{137}$ At OMB's insistence, ${ }^{138}$ the agency also provided disaggregated cost estimates, industry by industry, and disaggregated risk estimates. ${ }^{139}$ The Fifth Circuit, in reviewing EPA's rule in Corrosion Proof Fittings v. EPA, ${ }^{140}$ used these disaggregated estimates in concluding that the costs per life saved of the rule ranged from $\$ 7$ million to $\$ 8$ million (in the asbestos paper products industry) to $\$ 72$ million to $\$ 106$ million (in the asbestos shingles industry) ${ }^{141}$ Morrall reports EPA's 1986 asbestos rule as final with a cost of $\$ 104.2$ million per life saved. ${ }^{142}$ This happens to be within the range of the highest of the disaggregated cost estimates cited by the court.

The asbestos ban, however, never took effect. In Corrosion Proof Fittings, the Fifth Circuit found many reasons to overturn the EPA's rule. Among them was that, in the court's view, the costs of the rule exceeded its benefits. The court could not believe that in providing for the regulation of "unreasonable risk" under TSCA, Congress had meant for the agency to spend so much money to save so few lives:

While we do not sit as a regulatory agency that must make the difficult decision as to what an appropriate expenditure is to prevent someone from incurring the risk of an asbestos-related death, we do note that the EPA, in its zeal to ban any and all asbestos products, basically ignored the cost side of the TSCA equation. The EPA would have this court believe that Congress, when it enacted its requirement that the EPA consider the economic impacts of its regulations, thought that spending $\$ 200-300$ million to save approximately seven lives (approximately $\$ 30-40$ million per life) over thirteen years is reasonable.

The EPA's willingness to argue that spending $\$ 23.7$ million to save less than one-third of a life reveals that its economic review of its regulations, as required by TSCA, was meaningless. ... If we were to allow such cavalier treatment of the EPA's duty to consider the economic effects of its decisions, we would have to excise entire sections and phrases from the language of TSCA. Because we are judges, not surgeons, we decline to do so. ${ }^{143}$

137. See id. at 29,468 .

138. See Peter S. MENell \& Richard B. Stewart, Environmental LAW AND POLICY 103.06 (1994) (quoting Letter from Robert P. Bedell, Deputy Adm'r, Office of Info. and Regulatory Affairs, Office of Management and Budget, to A. James Barnes, Esq., Acting Deputy Adm'r, Environmental Protection Agency (Mar. 27, 1985) [hereinafter Bedell Letter]).

139. See Asbestos; Manufacture, Importation, Processing, and Distribution in Commerce Prohibitions, 54 Fed. Reg. at 29,484-85.

140. 947 F.2d 1201 (5th Cir. 1991).

141. See id. at 1222.

142. See Morrall, supra note 1 , at 30 tbl.4.

143. Corrosion Proof Fittings, 947 F.2d at 1222-23. 
Thus, the asbestos ban, like the regulations regarding benzene and radionuclides, was rejected based on the very reasoning that regulatory reformers have argued should underlie risk regulation. Indeed, Corrosion Proof Fittings is cited in the literature on regulatory reform as a model for sound decisionmaking. ${ }^{144}$ Again, therefore, the asbestos rule seems not to belong at the bottom of a list documenting the overall failure of risk regulation to take adequate account of costs.

Because the asbestos rule had not yet been overturned when Morrall initially prepared his list in 1986, inclusion of the rule on the list at that time was not unreasonable. Updated versions of the list, however, continue to include the asbestos rule-and even list it as "final"-despite its invalidation. ${ }^{145}$ The wrinkle here is that the rule was rejected by a court rather than by the agency that proposed it. Perhaps the rule is thus relevant to evaluating agency performance. In other words, the rule might be regarded as showing, not the shortcomings of legal requirements imposed by Congress (the interpretation of which ultimately led the Fifth Circuit to overturn the rule), nor of judicial review, but of agencies' implementation of statutory mandates.

The trouble with this idea is that Morrall's table has not been limited to the purpose of showing agencies' isolated shortcomings. To the contrary, it has been used as evidence of the need for wholesale reform of the risk-regulating system-including reform of the underlying substantive statutes and of the system for judicial review. ${ }^{146}$ But on these counts, the ultimate fate of the asbestos rule should be regarded as another victory for the regulatory reformers' agenda.

Moreover, if Morrall's list is to serve as a means of evaluating agency performance in isolation from the performance of statutory mandates and judicial review, then it contains some glaring omissions. One famous example of agency overreaching in the area of risk regulation is the 1976 Consumer Product Safety Commission's (CPSC) regulation of swimming pool slides. ${ }^{147}$ This safety regulation was overturned by the Fifth Circuit on the ground that the agency had not shown that the primary risk it targeted-a 1-in-10,000,000 risk of spinal injury and paralysis-would be appreciably reduced by the proposed rule. ${ }^{148}$ As Judge Wisdom stated in a concurring opinion, "The

144. See, e.g., Edward W. Warren \& Gary E. Marchant, "More Good Than Harm" A First Princtple for Environmental Agencies and Reviewing Couns, 20 ECOLOGY LQ. 379.382 (1993).

145. See, e.g., Lutter \& Morrall, supra note 2, at 59 tbl.6: Viscusi, supra note 2, at 1434 tbl.1. In his 1994 update to his own table, Morrall, without explanation. lowered the esumate of the costs per life saved of EPA's asbestos rule from $\$ 104.2$ million to $\$ 72.9$ million. See Lutter \& Morrall, supra note 2. at 59 tbl.6.

146. See, e.g., sources cited supra note 2 .

147. See Safety Standard for Swimming Pool Slides, 4 I Fod. Reg. 2742 (1976) (to be codıfied al 16 C.F.R. pt. 1207). For criticism of this rule as a case of agency overreaching. sec Cass $R$. Sunstein. Interpreting Statutes in the Regulatory State, 103 HARV. L. REV. 405, 478-79 (1989) (describing regulations such as CSPC's rule on swimming pool slides as an "excessive intrusion into the marketplace").

148. See Aqua Slide 'N' Dive Corp. v. Consumer Prod. Safety Comm'n. 569 F.2d 831. 840-44 (Sth 
benefits from these [regulations] have no reasonable relationship to the costs they will impose."149 Thus, as with the asbestos ban, two stories about the pool slide regulation are possible. In one view, it is an example of how the current regulatory system-which includes the process of judicial review-can catch the purportedly most extreme regulations, in which case it is a success story. Or it is an example of how agencies sometimes produce cost-ineffective rules, in which case it is a story of failure. If the latter is the message Morrall wanted to send regarding the asbestos ban, then he should have included the swimming pool regulation on his list, too. If he had done so, however, his conclusion about the relative cost-effectiveness of health and safety regulation ${ }^{150}$ would have begun to break down.

\section{d. Acrylonitrile (OSHA 1978)}

In January 1978, citing the "grave danger" posed by acrylonitrile as evidenced by animal and epidemiological studies showing an increased risk of cancer from acrylonitrile exposures, ${ }^{151}$ OSHA proposed an emergency temporary standard for the control of acrylonitrile exposures in the workplace. ${ }^{152}$ At the same time, OSHA also proposed a permanent standard for acrylonitrile. ${ }^{153}$ OSHA considered several alternatives for the permanent standard, including a permissible emission limit (PEL) of 2.0 parts per million (ppm) and a PEL of $1.0 \mathrm{ppm} .{ }^{154}$ In October 1978, OSHA issued a final rule on acrylonitrile, reflecting a PEL of $2.0 \mathrm{ppm}$. ${ }^{155}$

Morrall's list contains two 1978 OSHA rulemakings with respect to acrylonitrile; one rule is listed as final and one as rejected. ${ }^{156}$ According to Morrall, the final regulation cost far less per life saved than the rejected regulation ( $\$ 37.6$ million as compared to $\$ 308$ million). ${ }^{157}$ Although Morrall's 1986 list does not explicitly say so, it seems reasonable to conclude that the two 1978 acrylonitrile regulations appearing on his list-one rejected, one final-reflect the two regulatory alternatives mentioned above, the $1.0 \mathrm{ppm}$

Cir. 1978).

149. Id. at 845 (Wisdom, J., concurring).

150. See supra text accompanying notes $51-52$.

151. OSHA also emphasized research demonstrating that acrylonitrile produces other adverse health effects besides cancer, including birth defects, blood disorders, and neurological, respiratory, and gastrointestinal problems. See Emergency Temporary Standard for Occupational Exposure to Acrylonitrile (Vinyl Cyanide), 43 Fed. Reg. 2586, 2591-93 (1978) (to be codified at 29 C.F.R. pt. 1910) (proposed standard and notice of hearing, Jan. 17, 1978).

152. See id.

153. See Occupational Exposure to Acrylonitrile (Vinyl Cyanide), 43 Fed. Reg. 2608 (1978) (to be codified at 29 C.F.R. pt. 1910) (proposed standard and notice of hearing, Jan. 17, 1978).

154. See id. at $2610,2614$.

155. See Occupational Exposure to Acrylonitrile (Vinyl Cyanide), 43 Fed. Reg. 45,762 (1978) (to be codified at 29 C.F.R. pt. 1910).

156. See Morrall, supra note 1, at 30 tbl.4.

157. See id. 
PEL and the $2.0 \mathrm{ppm}$ PEL. This conclusion is buttressed by the fact that Morrall discusses these two alternatives in his 1983 article with Ivy Broder, and his figures on risks are identical in the 1983 and 1986 articles. ${ }^{158}$

The rejected alternative, proposing a PEL of $1.0 \mathrm{ppm}$, does not belong on Morrall's list. It was rejected before it ever imposed the costs of $\$ 308$ million per life saved reported by Morrall. Moreover, this stricter standard was rejected because OSHA found that it could not feasibly be imposed on the relevant industry. ${ }^{159}$ Granted, this focus on feasibility is not the kind of fine-tuned cost-benefit analysis that many regulatory reformers have endorsed. Yet even without this refined analysis, OSHA rejected the $1.0 \mathrm{ppm}$ alternative in favor of a more lenient standard. This should, by the regulatory reformers' lights, be another success story.

Moreover, it seems backwards to criticize regulatory performance based on the hypothetical costs imposed by a hypothetical alternative that the agency rejected in favor of a more cost-effective standard. Agencies are usually commended rather than chastised for considering a broad range of altematives. Morrall's approach to evaluating the work of agencies appears to be just the opposite: If an agency so much as mentions a possible regulatory alternative, even if the agency rejects the alternative in virtually the same breath as it mentions it, the costs of that alternative can thereafter be enshrined in a list designed to assess overall regulatory performance. ${ }^{160}$

158. Compare id. (reporting that the final acrylonitrile rule would save 6.9 lives per year. and the rejected acrylonitrile rule would have saved 0.6 additional lives per year). sith Broder \& Morrall. supra note 91 , at 250 tbl.15.2 (same).

159. See Occupational Exposure to Acrylonitrile (Vinyl Cyanide). 43 Fed. Reg. at 45.774.

160. One other fact about the rejected acrylonitrile regulation bears mentioning. As noted. in his 1983 article written with Ivy Broder, Morrall reported the costs and benefits of two regulalory alternatives-the PEL of $2.0 \mathrm{ppm}$ eventually adopted by OSHA and the rejocted PEL of $1.0 \mathrm{ppm}$. In addition. his 1983 estimates of the annual lives saved by each altemative were identical to his 1986 estumates of annual lives saved. In their 1983 estimates of the costs and benefits of the rejected PEL. however. Broder and Morrall reported only incremental costs and benefits, relative to the more lenient (and ultimately chosen) standard: that is, their estimates reported the cost per life saved of the additional life-saving benefits associated with the stricter rule. See Broder \& Morrall, supra note 91 , at 250 (bl.15.2 n.b. Given that the estumates of lives saved in the 1986 table are identical to the 1983 estimates. one must conclude that the 1986 table, too, reports only the incremental costs and benefits of the more stringent (and ultimately rejected) standard for acrylonitrile. The average costs per life saved of the rejected rule are significantly lowet than the incremental costs of this rule. Based on Broder and Morrall's 1983 figures, the average cost per life saved of the rejected acrylonitrile regulation was approximately $\$ 5.5$ million, as compared to the incremental cost per life saved of $\$ 28.8$ million (the total annualized cost of the $1.0 \mathrm{ppm}$ standard would have been $\$ 41.6$ million ( $\$ 24.3$ million plus $\$ 17.3$ million) divided by 7.5 total annual tives saved ( 6.9 plus 0.6$)$ ). See id. at 250 tbl. 15.2 (dividing total costs of $\$ 41.6$ million by 7.5 total lives saved). While many have argued that incremental costs and benefits are more pertinent to sensible policymaking than are average costs and benefits, see, e.g., OMB Position on Use of Risk Assessment. Cosi-Effectiveness Analysis. Benefir-Cost Review in Setting Stondards for Toxic Air Pollutants. 14 Env't Rep. (BNA) 1593. 1600 (Jan. 13. 1984) [hereinafter $O M B$ Pasition], reporting incremental costs for some regulations and average costs for others confuses evaluation of the rules on Morrall's list, especially since Morrall himself reports that the list generally reflects average costs, see Morrall, supra note 1 , at 31 . The regulations as to which incremental costs are reported will almost inevitably appear less attractive than the regulations as to which average costs are reported, merely as a function of the accounting convention used: the ineremental costs of environmental regulation are seldom lower than average costs. See BREYER, supra note 2. at 10-19 (elaborating on the problem of the "last 10 pereent," the premise of which is that incremental costs of 


\section{e. Summary}

I have described several rulemaking proceedings that, from all appearances, embody a regulatory approach consistent with the one advocated by regulatory reformers such as Morrall. It is thus more than a little awkward that these rulemaking proceedings-which all culminated in the rejection of a regulation deemed too costly in relation to its benefits-are made to appear, by their placement at the bottom of Morrall's list, as among the worst of the lot.

\section{Overinclusion: Rules That Do Not Exist}

Morrall's list also contains several rules that either were once proposed but were never issued or appear never to have existed at all. Such rules also do not belong on this list.

\section{a. Ethylene Dibromide (OSHA 1983)}

In 1983, OSHA proposed to limit workers' exposure to ethylene dibromide (EDB) by, among other things, lowering the permissible exposure limit for EDB from $20 \mathrm{ppm}$ to $0.1 \mathrm{ppm}$. $^{161}$ The agency estimated that, at that time, approximately 600 workers were continuously exposed to EDB and that one to eight excess cancers could be expected in this population as a result of such exposure. ${ }^{162}$ As for individual lifetime risk, the agency found that the risk of nasal tumors from EDB exposure reached as high as a stunning 725 in 1000 -a risk, OSHA noted, "far greater ... than for any other hazard that OSHA has regulated in the past, where the risks have been quantified." The agency also estimated that about 56,000 workers were intermittently exposed to EDB, but it found that it could not quantify the risks to these workers from this exposure. ${ }^{164}$ Nor was it able to quantify the risks of noncancer health effects, though it noted that dose-response relationships had been established for hepatic necrosis, toxic nephropathy, and reproductive

environmental protection and remediation are higher than average costs).

161. See Occupational Exposure to Ethylene Dibromide, 48 Fed. Reg. 45,956 (1983) (to be codified at 29 C.F.R. pt. 1910) (proposed Oct. 7, 1983).

162. See id. at 45,977 .

163. Id. at 45,975. A comparison of OSHA's estimates of the risks from EDB with Morrall's estimates is instructive because it begins to reveal how dramatically Morrall's estimates of risk sometimes depart from the agencies'. Morrall estimates the individual risks from EDB exposure to be 2.5 in 10,000 . See Morrall, supra note 1, at 30 tbl.4. As noted in the text, OSHA estimated that the risk of nasal tumors from EDB reached as high as 725 in $\mathbf{1 0 0 0}$. Thus Morrall's estimate of risk differs from OSHA's estimate by more than two orders of magnitude. Beyond saying that he sometimes chose what he regarded as more reliable estimates of risk than the agencies', see Morrall, supra note 1, at 28-29, Morrall does not explain this disparity.

164. See Occupational Exposure to Ethylene Dibromide, 48 Fed. Reg. at 45,977. 
toxicity. ${ }^{165}$ The agency also cited research showing that the carcinogenic effects of EDB were "considerably enhanced" when EDB exposure was combined with exposure to another chemical:; ${ }^{166}$ specifically, the carcinogenic effects of EDB and disulfiram together were eighty-five times higher than the effects of EDB alone, ${ }^{167}$ making EDB a "proven synergistic agent."168 This proposed regulation of EDB is the second-to-last regulation appearing on Morrall's list, with a cost of $\$ 15.6$ billion per life saved. ${ }^{169}$

Despite OSHA's findings on the risks of EDB, this regulation has never taken effect. Although the agency has never formally withdrawn the proposal, it seems safe to say-fourteen years later-that the proposal is dead. ${ }^{170}$ In 1986, when Morrall first compiled his list, it was understandable that he would include this rule. At that time, only three years had elapsed since the rule was first proposed, and many rules take longer than three years to become final. ${ }^{171}$ But it is hard to imagine a justification for including this longmoribund regulation on current versions of Morrall's list, which purport to reflect regulatory costs relevant to today's debates over the regulatory state. $^{172}$

\section{b. Arsenic and Copper Smelters (EPA 1986)}

In 1980, EPA listed inorganic arsenic as a hazardous air pollutant under section 112 of the Clean Air Act. ${ }^{173}$ EPA then proposed standards for arsenic emissions from two kinds of copper smelters: low-arsenic and high-arsenic smelters. ${ }^{174}$ In 1986, the agency issued a final rule regulating arsenic emissions from low-arsenic copper smelters alone. ${ }^{175}$ Morrall's list contains two 1986 rules on arsenic emissions from copper smelters, one designated

165. See id. at 45,974 .

166. Id. at 45,971 .

167. See id.

168. Id. at 45,974 .

169. See Morrall, supra note 1 , at 30 tbl.4.

170. The regulation has occasionally resurfaced in OSHA's descriptions of its regulatory agenda. See. e.g., Semiannual Agenda of Regulations, 54 Fed. Reg. 16.836. 16.841 (1989). The likely reason for OSHA's failure to issue a final rule on EDB is that, after OSHA proposed its EDB rule. EPA effectuvely banned EDB's use as a pesticide, thus eliminating most of the nsks OSHA had sought to prevent. See Tolerances and Exemptions from Tolerances for Pesticide Chemicals in or on Raw Agncultural Commodities; Revocation of Exemption from Tolerance for Ethylene Dibromide, 49 Fed. Reg. 17,144 (1984) (to be codified at 40 C.F.R. pt. 180).

171. See Sidney A. Shapiro \& Thomas O. MCGarity, Reorientung OSHA: Regulalon Altemattves and Legislative Reform, 6 YALE J. ON REG. 1, 39 \& n.228 (1989) (discussing the slow pace of OSHA rulemakings).

172. See, e.g., Viscusi, supra note 2, at 1434-35 tbl.I (including the rule in his table).

173. See National Emission Standards for Hazardous Air Pollutants; Addition of Inorganic Arsenic to List of Hazardous Air Pollutants, 45 Fed. Reg. 37,886 (1980).

174. See National Emission Standards for Hazardous Air Pollutants; Proposed Standards for Inorganic Arsenic, 48 Fed. Reg. 33,112 (1983) (to be codified at 40 C.F.R. pl. 6I) (proposed July 20, 1983).

175. See National Emission Standards for Hazardous Air Pollutants; Standards for Inorganic Arsenic. 51 Fed. Reg. 27,956 (1986) (to be codified at 40 C.F.R. pt. 61). 
"Arsenic/Copper Smelter" and the other, "Arsenic/Low-Arsenic Copper."176 Morrall's "Arsenic/Copper Smelter" rule must then refer to the regulation of high-arsenic copper smelters. Morrall reports that the "Copper Smelter" rule is final and costs $\$ 26.5$ million per life saved. ${ }^{177}$ This rule does not exist.

In its final rule on inorganic arsenic emissions, EPA reported that the standard it had proposed for high-arsenic copper smelters would have affected only one copper smelter in the country, the smelter owned by ASARCO, Inc., located in Tacoma, Washington. ${ }^{178}$ The agency also reported that ASARCO had, the month before, announced that it would close this smelter. ${ }^{179}$ This announcement was the rather disappointing climax to an unusual series of public hearings in which EPA officials had encouraged the participation of local residents in the determination of an ample margin of safety for restrictions on arsenic emissions from the Tacoma smelter. ${ }^{180}$

Because ASARCO had decided to close the only high-arsenic copper smelter in the country, EPA withheld further action on high-arsenic copper smelters and announced that it would "reconsider the need for a separate standard applicable to existing high-arsenic smelters if there is evidence that ASARCO-Tacoma will resume copper smelting operations." ${ }^{181}$ As a consequence, the agency promulgated only one standard for arsenic emissions from copper smelters, not the two that Morrall lists. Contrary to Morrall's report, therefore, there is no copper smelter rule imposing $\$ 26.5$ million in costs per life saved.

One might argue that inclusion of the "copper smelter" standard on this list is appropriate because ASARCO, at least, claimed that one reason for the closure of its copper smelter was the burden of the anticipated new environmental regulations. ${ }^{182}$ Thus, it might be argued that, even though the withdrawn rule itself did not impose costs on ASARCO, the prospect of having to comply with the proposed rule was so fearsome that the company

176. Morrall, supra note 1 , at 30 tbl.4.

177. See id.

178. See Standards for Inorganic Arsenic, 51 Fed. Reg. at 27,957.

179. See id.

180. Assessments of this experiment in participatory risk management are mixed. For an optimistic account, see Robert B. Reich, Public Administration and Public Deliberation, 94 YALE L.J. 1617 (1985). For less sanguine appraisals, see David Doniger, The Gospel of Risk Management: Should We Be Converted?, [1984] 14 Envtl. L. Rep. (Envtl. L. Inst.) 10,222, 10,223 (June 1984); and Peter Dorman, Environmental Protection, Employment, and Profit: The Politics of Public Interest in the Tacoma/Asarco Arsenic Dispute, REV. RADICAL POL. ECON., Winter 1984, at 151. See also AMY GUTMANN \& DENNIS THOMPSON, DEMOCRACY AND DISAGREEMENT I65-98 (1996) (analyzing the role of utilitarianism in the ASARCO dispute).

181. Standards for Inorganic Arsenic, 51 Fed. Reg. at 27,957. There is little chance that the ASARCO smelter will resume operations any time soon because it has been dismantled. See Kery Murakami, Famous Tacoma Stack Coming Down Sunday, SeATTLE TIMES, Jan. 13, 1993, at A1.

182. See Copper Smelter Closes on Coast as Market Shrinks for Metal, N.Y. TIMES, Mar. 26, 1985, at Al4. 
chose to close the plant rather than comply. ${ }^{183}$ The closure of the plant was, on this view, a cost of the proposed rule even though the rule never went into effect. Accounts by sources other than ASARCO, however, blamed the closure on falling copper prices, ${ }^{184}$ and ASARCO itself conceded that it was not the proposed arsenic regulation, but new restrictions on sulfur dioxide emissions, that most contributed to the decision to close. ${ }^{185}$ Thus, the proposed, but never issued, high-arsenic rule does not belong on Morrall's list.

\section{c. Arsenic and Glass Manufacturing Plants (EPA 1986)}

At the same time that it issued a regulation pertaining to arsenic emissions from copper smelters, EPA also regulated arsenic emissions from glass manufacturing plants. Morrall lists two 1986 EPA rules on such emissions (designated "Arsenic/Glass Plant" and "Arsenic/Glass Manufacturing"). ${ }^{185} \mathrm{He}$ reports the "glass plant" rule as final and the "glass manufacturing" rule as rejected. ${ }^{187}$ According to his list, the final glass plant rule cost $\$ 19.2$ million per life saved, and the rejected glass manufacturing rule would have cost $\$ 142$ million per life saved. ${ }^{188}$

But there was only one 1986 EPA rulemaking involving inorganic arsenic emissions from any kind of "glass plant," and this was the rulemaking regarding glass manufacturing plants. ${ }^{189}$ How Morrall determined that there were separate rules for "glass plants" and "glass manufacturing" is unknown, let alone how he determined that one rule was rejected and one final, and that one cost $\$ 19.2$ million per life saved and the other $\$ 142$ million per life saved. ${ }^{190}$ The more expensive, rejected rule does not exist.

183. For a discussion of the effect of proposed regulation on industry behavior, see Nicholas $A$. Ashford \& George R. Heaton, Jr., Regulation and Technological Innosasion in the Chemical Indusiry. Law \& CONTEMP. PROBS., Summer 1983, at 109, 120 (arguing that OSHA's behavior may change businesses' perceptions of the need to change their technological courses).

184. See, e.g., Felicity Barringer, EPA Asts Residents' Advice About Arsenic Plant, Wash. POST. July 14, 1983, at A13 (describing a report by EPA economist Rober L. Coughlin concluding that economic factors would probably force closure of the ASARCO plant within five years).

185. See Cass Peterson, High-Pollution Smelter To Close Within a Year: Asarco Cutes Environmental Regulations, WASH. POST, June 29, 1984, at A2 (stating that the cost of the arsenic rule would be only $\$ 3$ million).

186. Morrall, supra note 1, at 30 tbl.4.

187. See id.

188. See id.

189. See National Emission Standards for Hazardous Air Pollutants: Standards for Inorganic Arsenic, 51 Fed. Reg. 27,956 (1986) (to be codified at 40 C.F.R. pt. 61).

190. I shall have more to say about EPA's final glass plant rule in discussing Morrall's estumates of risks and costs. See infra Subsection II.B.l.c. 


\section{d. Radionuclides and Uranium Mines (EPA 1984)}

In its 1983 proposed rule on radionuclides, which I have already discussed, ${ }^{191}$ EPA also proposed limiting emissions from uranium mines. ${ }^{192}$ In its 1984 decision on radionuclides, however, the EPA withdrew its proposed standards for uranium mines after finding that its proposed standard contained two legal flaws. ${ }^{193}$ The 1984 ruling regarding radionuclide emissions from uranium mines, listed as final on Morrall's list, was thus a decision to withdraw regulation rather than impose it. ${ }^{194}$ Thus, this decision, too, should have been excluded from the list. ${ }^{195}$

\section{e. Summary}

The discussion so far suggests that, from the standpoint of legal status, Morrall's list, and updated versions of it, are quite overinclusive. There is little justification for including on this list rules that were rejected on the ground that their benefits did not justify their costs. Regardless of whether the agency or a court made the decision not to impose such a rule, such a decision should be seen, from the regulatory reformers' perspective, as a success story. There is also little reason to include on the list rules that do not exist. Overinclusiveness is, however, just one of the problems with Morrall's list.

\section{Underinclusion: Excluded Rules and Failures To Regulate}

Morrall's list is also underinclusive in two important respects. First, the list excludes several prominent agency rules about which comprehensive information on costs and benefits existed at the time Morrall prepared his 1986 list. These rules apparently satisfied Morrall's stated criterion for inclusion of rules on the list-the availability of "reasonably complete" information on costs and benefits ${ }^{196}$ - yet he excluded them anyway. The cost profiles

191. See supra Subsection II.A.1.b.

192. See National Emission Standards for Hazardous Air Pollutants; Standards for Radionuclides, 48 Fed. Reg. 15,076, 15,083-84 (1983) (to be codified at 40 C.F.R. pt. 61) (proposed Apr. 6, 1983).

193. The agency concluded, first, that the dispersion technology it had proposed for control of radionuclide emissions from uranium mines was not a lawful means of emission control under section 112 of the Clean Air Act and, second, that the proposed rule failed to satisfy the statute's public health purposes by not reducing aggregate population risk. See National Emission Standards for Hazardous Air Pollutants; Regulation of Radionuclides, 49 Fed. Reg. $43,906,43,912-13$ (1984) (to be codified at 40 C.F.R. pt. 61) (withdrawal of proposed standards, Oct. 31, 1984).

194. At the same time, the agency announced that it would attempt to develop a standard for uranium mines based on new and lawful methods of control. See id. at 43,913. The agency eventually issued standards for these sources in 1989. See National Emission Standards for Hazardous Air Pollutants; Radionuclides, 54 Fed. Reg. 51,654 (1989) (to be codified at 40 C.F.R. pt. 61).

195. It is worth noting, once again, that Morrall's estimate of the lives that would have been saved annually by this rule (1.1 lives) is much lower than EPA's estimate (five). Compare Morrall, supra note 1, at 30 tbl.4, with Regulation of Radionuclides, 49 Fed. Reg. at 43,912.

196. Morrall, supra note 1, at 27. 
associated with these rules challenge Morrall's sweeping conclusion about the cost-ineffectiveness of health regulation. ${ }^{197}$ EPA's phase down of lead in gasoline, ${ }^{198}$ for example, was estimated to produce net monetary benefits; in other words, its cost per adverse health condition avoided (primarily impaired cognitive development in children and elevated blood pressure in adults) was less than zero. ${ }^{199}$ Similarly, the Clean Air Act's provisions controlling common air pollutants (particulates, sulfur dioxide, ozone, carbon monoxide, and nitrogen dioxide) ${ }^{200}$ were estimated to have produced approximately $\$ 37.3$ billion in benefits in 1978 alone, and this was assuming that each human life had a value of only $\$ 1$ million. ${ }^{201}$ These benefits dwarfed annual costs, estimated at approximately $\$ 13.7$ billion for $1981 .^{202}$

A second way in which Morrall's list is underinclusive is that it does not evaluate the costs and benefits of complete failures to regulate. It evaluates the costs and benefits of failures to regulate only when nonregulation followed a proposal to regulate, as with the withdrawn restrictions on benzene and radionuclides. ${ }^{203}$ It does not report, to name two examples, the costs and benefits of the twenty-year-long failure of the EPA to use the Clean Air $\mathrm{Act}^{204}$ to address the problem of acid deposition, ${ }^{205}$ or the failure of OSHA to address the risks posed by thousands of industrial chemicals that have been shown to have toxic effects or that are suspected carcinogens. ${ }^{206}$ Yet the costs and benefits of failures to regulate should play a role in any overall evaluation of the regulatory system. By evaluating failures to regulate, one might begin to suspect, not that the regulatory system has reached too far, but that it has not reached far enough. ${ }^{207}$

Given that "reasonably complete" information was available with respect to many regulations and failures to regulate that were excluded from Morrall's

197. See supra text accompanying notes $51-52$.

198. See Regulation of Fuels and Fuel Additives; Gasoline Lead Content. 50 Fed. Reg. 9386 (1985) (to be codified at 40 C.F.R. pt. 80).

199. See JoEl SCHWARTZ ET AL., ENVIRONMENTAL PROTECTION AGENCY. COSTS AND BENEFTtS OF REDUCING LEAD IN GASOLINE: FINAL REgULATORY IMPACT ANALYSIS al VIll-26 Ibl.VIII-8 (1985).

200. See 42 U.S.C. $\$ \S 7408-7410$ (1994).

201. See Paul R. Portney, Air Pollution Policy, in PUblic POLICIES for Exvironsental Protection 27, 54-60 (Paul R. Portney ed., 1990) (discussing A. MYRICK FreEMAN III. AIR AND W ATER POLLUTION CONTROL: A BENEFTT-COST ASSESSMENT (1982); A. MYRICK FREEMAN III. THE BENEFITS OF AIR AND WATER POLLUTION CONTROL: A REVIEW AND SYNTHESIS OF RECENT ESTIMATES. REPORT TO THE. COUNCIL ON ENVIRONMENTAL QUALITY (1979)).

202. See id. at 69-70 (discussing MICHAEL HAZILLA \& RAYMONd J. KOPP. THE SOCiAl COST OF ENYIRONMENTAL QUALITY REgULATIONS: A GENERAL. EquILIBRIUM ANalysis (Resources for the Future Discussion Paper QE86-02, 1986)).

203. See supra Subsections I1.A.1.a-b.

204. 42 U.S.C. $\$ \S 7401-7671$.

205. See Heinzerling, supra note 64, at 319.

206. See MCGARITY \& SHAPIRO, supra note 91. at 13.

207. Of course, it would not be practicable to insist upon an examination of the costs per life saved of every potential life-saving regulation; such a project would quickly become unmanageable. Nevertheless, one should at least acknowledge that data on the costs per life saved by enacted regulations tells only one side of the story. 
list, one is left to speculate about the true criteria for inclusion of rules on the list. In this regard, it is striking to notice how many of the rules at the bottom of the list had drawn criticism from either the Council on Wage and Price Stability (COWPS) ${ }^{208}$ during the 1970 s or $\mathrm{OMB}^{209}$ in the 1980 s, while Morrall was working at those agencies. COWPS criticized OSHA's rules regulating acrylonitrile, ${ }^{210}$ arsenic, ${ }^{211}$ benzene, ${ }^{212}$ and coke ovens. ${ }^{213}$ $O M B$ forced a softening of OSHA's rules on ethylene oxide ${ }^{214}$ and formaldehyde ${ }^{215}$ and pointedly criticized EPA's rules on arsenic, ${ }^{216}$ asbestos, ${ }^{217}$ and radionuclides. ${ }^{218}$ During the years in question, COWPS and OMB took it as their mission to bring cost-benefit analysis to the regulatory process. ${ }^{219}$ COWPS even took the nonobvious position that its statutory charge of assessing the effects of regulatory action on inflation included evaluating regulations according to cost-benefit analysis. ${ }^{220}$ COWPS frequently criticized OSHA for "steadfastly refrain[ing]" from quantifying the number of lives that would be saved by its regulations, ${ }^{221}$ and for failing to

208. For a concise description of COWPS's oversight authority, see Harold H. Bruff, Presidential Management of Agency Rulemaking, 57 GEO. WASH. L. REV. 533, 546-48 (1989). See also SAMUEL P.

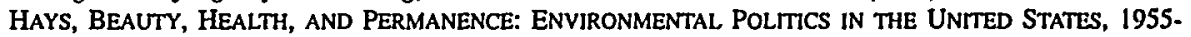
1985 , at $372-73$ (1987).

209. On OMB's role in regulatory oversight, see, for example, Alan B. Morrison, OMB Interference with Agency Rulemaking: The Wrong Way To Write a Regulation, 99 HARV. L. REV. 1059 (1986); and Erik D. Olson, The Quiet Shift of Power: Office of Management \& Budget Supervision of Environmental Protection Agency Rulemaking Under Executive Order 12,29I, 4 VA. J. NATURAL RESOURCES L. 1 (1984).

210. See Thomas D. Hopkins et al., COUNCIL ON WAGE AND PRICE STABIL.ITY, EXECUTIVE OfFice OF THE PRESIDENT, A REVIEW OF THE REGULATORY INTERVENTIONS OF THE COUNCIL ON WAGE AND PRICE STABILITY 1974-1980, at B-65 to B-68 (1981). Morrall himself prepared the analysis of the rule for COWPS. See Broder \& Morrall, supra note 91, at 349 n.31 (citing JOHN MORRALL, COUNCIL ON WAGE AND PRICE STABILITY, REPORT SUBMITTED TO RARG ON OCCUPATIONAL EXPOSURE TO ACRYLONITRILE 272 (1978)).

211. See Dianne R. Levine, Exposure to Inorganic Arsenic in the Workplace, in BENEFTT-COST ANALYSES OF SOCIAL REGULATION 21, 24-27 (James C. Miller III \& Bruce Yandle eds., 1979).

212. COWPS criticized OSHA's original benzene rule, which as I note below, see infra text accompanying note 378, was identical to the rule proposed after remand from the Supreme Court and which appears on Morrall's list. See COUNCIL ON WAGE AND PRICE STABILITY, APPENDIX: ANALYSIS OF PROPOSED BENZENE STANDARD (1977). For a discussion of COWPS's objections, sec Brief for Respondents at 18-20, Industrial Union Dep't, AFL-CIO v. American Petroleum Inst., 448 U.S. 607 (1980) (No. 78-911).

213. See Exposure to Coke Oven Emissions: Proposed Standard Before the Occupational Safety and Health Administration, Docket No. H-017A, at 9-12 \& tbl.D (1976) [hereinafter Exposure to Coke Oven Emissions] (statement of John F. Morrall III, Senior Economist, on Behalf of COWPS).

214. The legality of OMB's interference with the ethylene oxide rulemaking was raised, but not decided, in Public Citizen Health Research Group v. Tyson, 796 F.2d 1479, 1483-84 (D.C. Cir. 1986). See also MCGARITY \& SHAPIRO, supra note 91, at 85-87.

215. See MCGARITY \& SHAPIRO, supra note 91, at 108-11, 159-61.

216. See OMB Position, supra note 160.

217. See MENELL \& STEWART, supra note 138, at 105-06 (quoting Bedell Letter, supra note 138).

218. See OMB Position, supra note 160.

219. For a history of COWPS's (successful) efforts to bring cost-benefit analysis to NHTSA, see Jerry

L. Mashaw \& David L. Harfst, Inside the National Highway Traffic Safety Administration: Legal Determinants of Bureaucratic Organization and Performance, 57 U. CHI. L. REV. 443, 467-69 (1990).

220. See Levine, supra note 211 , at 27 .

221. Id. at 25 . 
assign a monetary value to human life. ${ }^{22}$ In OMB's hands, cost-benefit analysis became a one-way ratchet; it was used to criticize proposals for regulation, never to criticize failures to regulate. ${ }^{223}$ The bottom of Morrall's table, in short, reads like a COWPS/OMB regulatory hit list, and this is not a point in favor of its objectivity. ${ }^{224}$

\section{Conclusion}

I have argued that eight out of the eleven rules at the very bottom of Morrall's list, and several others, do not belong on the list at all, either because they were rejected for the very reason that their costs exceeded their benefits or because they have, for other reasons, never taken effect. Excluding these rules dramatically narrows the range of cost-effectiveness reflected on Morrall's list. As I discuss in the next section, this range narrows still more when the agencies' estimates of risks and costs-rather than Morrall's-are used to derive the figures on cost-effectiveness.

\section{B. Competing Estimates of Costs per Life Saved}

The selection of rules for Morrall's list is not the only shortcoming of the list. The costs per life saved reported by Morrall are also problematic. This section compares Morrall's estimates of the risks avoided by the regulations on his list and the costs they would impose with the agencies' estimates of those risks and costs. As we shall see, Morrall's estimates are strikingly different from-and inevitably higher than-the agencies' estimates. Indeed, as I explain below, there is as much as a 1000-fold variance between Morrall's estimates of costs per life saved and the agencies' (often implicit) estimates of these costs. ${ }^{225}$ These differences appear to stem from two sources: Morrall's discounting of the number of lives the regulations were expected to save in the future by ten percent per year and his adjustments to the agencies' quantitative risk assessments. ${ }^{226} \mathrm{I}$ organize my discussion in this section along these lines. ${ }^{227}$

222. See id. at 27.

223. See PERCIVAL ET AL., supra note 72, at 694.

224. It is interesting to note that another of the rare attempts to identify the costs per life saved of federal regulations also relied extensively on COWPS's calculations of regulatory cosis. and the rules covered by these calculations fared poorly on that list 100 . See John D. Graham \& James W. Vaupel. The Value of a Life: What Difference Does It Make?, in WHAT ROLE FOR GOVERNMENT?, supra note 91, at 176, 179-83 tbl.11.1.

225. For a summary of the findings in this section, see infra note 392.

226. For a more detailed description of discounting future lives saved and of quantitalive risk assessment, see infra Subsections III.A.1-2.

227. I focus on the regulations that have been asserted to fail any one of the currently circulating tests for determining the wisdom of social regulations (such as cost-benefit analysis). These are the regulations that, on Morrall's list, appear below EPA's 1984 rule regarding fugitive emissions of benzene, see, e.g. VISCUSI, supra note 2, at 264 tbl.14-5 (asserting that regulations listed below benzenelfugitive emissions 


\section{Discounting}

Explaining why Morrall's estimates of costs per life saved differ so stunningly from the agencies' estimates is largely a process of elimination. These differences are not in any case attributable to different estimates of regulatory compliance costs; Morrall did not alter the agencies' cost estimates. ${ }^{228}$ Nor, as to the rules discussed in this subsection, are the differences attributable to different estimates of risk; for these rules, Morrall's estimates of actual lives saved are identical or nearly identical to the agencies' estimates. In addition, the differences in estimates of costs per life saved are too large to be attributable to any effects of price inflation in the interval between the agencies' estimates and Morrall's. ${ }^{229}$ The only other adjustment that Morrall reports he made to the agencies' estimates was to discount future lives saved by ten percent per year. ${ }^{230}$ Thus, with respect to the rules discussed in this subsection, the vast difference between Morrall's and the agencies' estimates of costs per life saved must be attributed to discounting. ${ }^{231}$

\section{a. Asbestos (OSHA 1972), Acrylonitrile (OSHA 1978), and Arsenic (OSHA 1978)}

Morrall included on his list three rules that OSHA enacted before the agency began estimating the number of lives that would be saved through its regulation of various workplace health risks. ${ }^{232}$ Thus, in none of these cases can we isolate the effect of discounting on Morrall's calculations by comparing the agency's estimates with Morrall's. ${ }^{233}$ We can, however, discern the effect of discounting on Morrall's 1986 estimates by comparing them with estimates

fail the cost-benefit test), which Morrall finds to cost $\$ 2.8$ million per life saved, see Morrall, supra note 1 , at 30 tbl.4.

228. See Morrall, supra note 1, at 29.

229. Cf. infra note 397 (adjusting agencies' estimates of costs based on the Consumer Price Index).

230. See Morrall, supra note 1 , at 28.

231. In order to isolate the effect of discounting on Morrall's estimates, I report the agencies' estimates of risks and costs without any discounting. I discuss the appropriateness of discounting the future benefits of health regulation infra Part III.

232. See Occupational Exposure to Acrylonitrile (Vinyl Cyanide), 43 Fed. Reg. 45,762 (1978) (to be codified at 29 C.F.R. pt. 1910); Occupational Exposure to Inorganic Arsenic, 43 Fed. Reg. 19,584 (1978) (to be codified at 29 C.F.R. pt. 1910); Standard for Exposure to Asbestos Dust, 37 Fed. Reg. 11,318 (1972) (to be codified at 29 C.F.R. pt. 1910). In 1980, a plurality of the Supreme Court held that OSHA must first find a risk "significant" before regulating it, see Industrial Union Dep't, AFL-CIO v. American Petrolcum Inst., 448 U.S. 607, 642 (1980) (plurality opinion), which greatly increased the use of quantitative risk assessment. See John S. Applegate, The Perils of Unreasonable Risk: Information, Regulatory Policy, and Toxic Substances Control, 91 COLUM. L. REv. 261, 283-84 (1991).

233. See Occupational Exposure to Acrylonitrile (Vinyl Cyanide), 43 Fed. Reg. at 45,790 ("While the actual estimation of the number of cancers to be prevented is highly uncertain, the evidence indicates that the number is likely to be appreciable."); Occupational Exposure to Inorganic Arsenic, 43 Fed. Reg. at 19,607 ("[T] he actual estimation of the number of cancers to be prevented is highly uncertain."); Standard for Exposure to Asbestos Dust, 37 Fed. Reg. at 11,318 (presenting no agency estimate). 
offered in Morrall's 1983 article written with Ivy Broder. ${ }^{234}$ In that article, Morrall and Broder did not discount future lives saved. ${ }^{235}$ The following table compares the two sets of estimates of risks and costs:

\section{TABLE 2. COST-EFFECTIVENESS OF OSHA REgULATIONS: MORRALL (1983) vS. MORRALL (1986) ${ }^{236}$}

\begin{tabular}{|l|l|l|l|l|}
\hline REGULATION & $\begin{array}{l}\text { MORRALL 1983: } \\
\text { ANNUAL LIVES } \\
\text { SAVED }\end{array}$ & $\begin{array}{l}\text { MORRALL 1986: } \\
\text { ANNUAL LIVES } \\
\text { SAVED }\end{array}$ & $\begin{array}{l}\text { MORRALL 1983: } \\
\text { COST PER LIFE } \\
\text { SAVED } \\
\text { (MILLONS) }\end{array}$ & $\begin{array}{l}\text { MORRALL 1986: } \\
\text { COST PER LIFE } \\
\text { SAVED } \\
\text { (MILLONS) } \\
\text { (1984 DOLLARS) }\end{array}$ \\
\hline \hline $\begin{array}{l}\text { Asbestos } \\
\text { (OSHA 1972) }\end{array}$ & 396.00 & 396.00 & $\$ 0.189$ & $\$ 7.4$ \\
\hline $\begin{array}{l}\text { Acrylonitrile } \\
\text { (OSHA 1978) }\end{array}$ & 6.90 & 6.90 & 3.50 & 37.60 \\
\hline $\begin{array}{l}\text { Arsenic } \\
\text { (OSHA 1978) }\end{array}$ & 5.40 & 11.70 & 20.20 & 92.50 \\
\hline
\end{tabular}

In both 1983 and 1986, Morrall estimated that OSHA's asbestos rule would save 396 lives per year, yet his estimate of the cost per life saved of this rule grew almost forty times between 1983 and $1986 .{ }^{237}$ Likewise, he reported in both 1983 and 1986 that the acrylonitrile rule would save 6.9 lives annually, yet his 1986 estimate of costs per life saved is more than ten times higher than his 1983 estimate. ${ }^{238}$ In addition, despite the more than doubling of his estimate of the number of lives saved by the arsenic regulation (from 5.4 in 1983 to 11.7 in 1986), Morrall reported in 1986 that the cost per life saved of this rule was over four times as high as he had reported in 1983. These

234. See Broder \& Morrall, supra note 91.

235. Rather than discounting lives saved. Morrall and Broder discounted the esumates of the monetary value of life reflected in workers' and consumers' willingness to pay for nsk reductions. See id. al 253. They reasoned that the estimates from existing studies were based on the nsk of accidents leading to immediate death rather than the risk of contracting cancer after a long latency period and that valuations would be lower for more remote harms. See id. at 252-53. For a more detailed discussion of the concept of discounting human lives, see infra Subsection IIl.A.1.

236. For the sources of these figures, see Broder \& Morrall, supra note 91, at 250 tbl.15.2; and Morrall, supra note 1, at 30 tbl.4.

237. In 1983, Morrall thought that his figures on risks and costs probably "underestumate ... deaths prevented and . . overestimate . . costs per life saved." Broder \& Morrall, supra note 91, at 250 tbl.15.2 n.a.

238. The same general observation applies to the rejected acrylonitrile standard. which. as I have argued, see supra Subsection Il.A.l.d, does not belong on Morrall's table: In 1983 Morrall estumated that this standard would save 0.6 lives at a cost of $\$ 28.8$ million apiece. but by 1986 the cost for the same benefit had swollen to $\$ 308$ million. Compare Broder \& Morrall, supra note 91, at 250 tbl.15.2, with Morrall, supra note 1, at 30 tbl.4. 
large differences must be due to discounting, as this is the only methodological difference between the two sets of estimates. ${ }^{239}$

\section{b. Arsenic and Low-Arsenic Copper Smelters (EPA 1986)}

As noted earlier, ${ }^{240}$ as a result of its listing of inorganic arsenic as a hazardous air pollutant under section 112 of the Clean Air Act, EPA promulgated in 1986 a rule pertaining to low-arsenic copper smelters. ${ }^{241}$ The rule required primary copper smelters to control arsenic emissions through application of the technology that would provide "the maximum reduction in risk to public health and is available and can be applied without causing widespread plant closure or imposing costs that far exceed any public health benefit." 242 Although the agency originally believed that the new standard would affect six of the fourteen primary smelters in operation at the time, ${ }^{243}$ the agency's final standard required further controls at only one smelter in the country, the ASARCO smelter in El Paso, Texas. ${ }^{244}$ The agency reasoned as follows:

For five of the six smelters that the proposed standard would have affected, EPA concluded that the costs were disproportionate to the risk reductions that could be obtained. Furthermore, the revised economic analysis showed that for two of these five smelters the

239. Morrall does not cite a source for his estimates of the number of lives saved by these rules, and as noted, see supra notes 232-233 and accompanying text, we do not have agency estimates to consider in these cases. There is, however, some reason to be skeptical of Morrall's estimates of lives suved. For example, an analysis of OSHA's proposed arsenic standard, performed by COWPS, took a stab at estimating how many lives would be saved by the rule and came up with a range of 12 to 106 lives saved per year. See Levine, supra note 211 , at 25 . The low extreme of this range is almost identical to Morrall's 1986 estimate of 11.7 lives saved annually. The COWPS analysis-admittedly "not the work of a technical expert in the area of epidemiology," id. at 24-was based on the application of "alternative hypotheses about the relationship between dose and response" for arsenic and cancer, $i d$. at 25 . No effort was made to select a best estimate, although the analyst-who was, to repeat, not an expert in this field-believed that all the estimates "grossly overestimate the benefits from the proposed standards." Id. at 26. COWPS reported that the cost per life saved of the arsenic rule was between $\$ 1$ million and $\$ 9$ million. See id. at 27. Even the upper end of this range is an order of magnitude below Morrall's 1986 estimate. Amid this much variability, it is hard to know which of these estimates is closest to the one the agency might have embraced had it estimated costs per life saved. For the purposes of summarizing my findings with respect to costs per life saved, I use Broder and Morrall's 1983 estimate (divided in half to reflect Morrall's 1986 doubling of his estimate of lives saved) only because I use Broder and Morrall's estimates with respect to other OSHA rules for which there are no agency estimates of risks. See infra note 392. Note, however, that if COWPS's figures are closer to the mark, the costs per life saved which I report for OSHA's arsenic rulc, see infra note 392, are approximately two to twenty times too high.

COWPS also estimated the costs of the acrylonitrile standard. Its estimate of $\$ 1.37$ million per cancer case avoided is a far cry from Morrall's 1986 estimate of $\$ 37.6$ million for the same benefit. Compare HOPKINS ET AL., supra note 210, at B-66, with Morrall, supra note 1, at 30 tbl.4.

240. See supra Subsection II.A.2.b.

241. See National Emission Standards for Hazardous Air Pollutants; Standards for Inorganic Arsenic, 51 Fed. Reg. 27,956 (1986) (to be codified at 40 C.F.R. pt. 61).

242. Id. at 27,972 .

243. See id. at 27,969 .

244. See id. at 27,970 . 
control costs were likely to result in the smelters remaining permanently closed. The analysis of the converter control requirement also indicated that for the sixth facility, ASARCO-El Paso, that risk reduction could be obtained at a cost that does not present unreasonable economic and social effects. ... Consequently, EPA revised the cutoff to distinguish between primary copper smelters where additional emission control is reasonable and those where control imposes costs that far exceed any public health benefit. ... Based on available information, this cutoff requires application of converter secondary controls only at the ASARCO-El Paso smelter. ${ }^{245}$

In other words, based on an assessment of risks, costs, and technological feasibility, EPA set the new emissions standard at precisely the level that would capture the only smelter in the country where the agency reckoned further controls would be cost-justified. This hardly seems to be an example of an agency run amok. In fact, the agency's approach here appears to follow OMB's recommendation, offered to EPA during the Reagan administration, that the agency look at incremental-indeed, site-specific-costs and benefits in setting emission standards for toxic pollutants. ${ }^{246}$ Nevertheless, the rule on low-arsenic copper smelters has the dubious distinction of appearing fifth from the bottom on Morrall's list.

The rule fares so poorly on the list because, according to Morrall, it costs $\$ 764$ million per life saved. ${ }^{247}$ As noted, however, EPA itself reported that the rule would require new controls at only one facility, the ASARCO-EI Paso smelter. For this smelter, EPA estimated the costs to be $\$ 1.85$ million in capital costs, leading to $\$ 379,000$ in annualized costs. ${ }^{2 \$ 8}$ EPA also estimated that the rule would save .09 lives per year ${ }^{249}$-or approximately one life every eleven years. Using rough calculations, this amounts to approximately $\$ 4,169,000$ per life saved in the first eleven years of the rule's operation. ${ }^{230}$ Thus, using EPA's estimates of risks and costs, the costs per life saved of this regulation are more than two orders of magnitude below those reported by Morrall. This difference must be due entirely to discounting, as Morrall's

245. Id. at 27,975 .

246. See OMB Position, supra note 160, at 1600. In effect, therefore, the costs reported for this regulation-like those reported for the rejected acrylonitrile standard previously discussed. see supro Subsection II.A.1.d; supra note 160-are incremental costs.

247. See Morrall, supra note 1 , at 30 tbl.4.

248. See Standards for Inorganic Arsenic, 51 Fed. Reg. at 27,971.

249. See id. at 27,970 (reporting that the annual cancer incidence would be reduced from .38 to 29 cases per year-thus saving .09 lives annually).

250. To arrive at this figure, I multiplied EPA's estumate of annualized costs $(\$ 379.000)$ by 11 (as the rule would save one life approximately every 11 years). 
estimate of 0.9 annual lives saved is identical to EPA's, ${ }^{251}$ and he did not adjust the agency's estimate of compliance costs. ${ }^{252}$

\section{c. Arsenic and Glass Manufacturing Plants (EPA 1986)}

EPA's 1986 rule pertaining to arsenic emissions also deals with glass manufacturing plants that use commercial arsenic as a raw material. ${ }^{253}$ Among other things, the rule requires existing glass plants to limit their emissions of arsenic to 2.75 tons per year, or, in the alternative, to reduce emissions by at least $85 \% .{ }^{254}$ At the time the rule was promulgated, the agency reported that there were a total of seventy-five glass furnaces, at twenty-seven different plants, which used arsenic as a raw material. ${ }^{255}$ The agency also noted, however, that nearly $80 \%$ of the total arsenic emissions in the country at that time came from just eleven uncontrolled furnaces at five separate plants. ${ }^{256}$ The agency eventually focused on six glass plants, which together were responsible for $90 \%$ of the emissions and their corresponding risks. ${ }^{257}$ The agency found that requiring further controls at the other existing glass plants would impose "excessive" costs in relation to the small risks that would be avoided. ${ }^{258}$ Even among the six highest-polluting plants, however, the agency ultimately concluded that further controls were warranted at only two of them. The agency explained its decision as follows:

Based on a consideration of these risk and cost data, it was concluded that further control should be required at the Martinsburg and Charleroi plants. However, at the other four plants where risk and achievable risk reduction potential are lower, it was concluded that further control is not necessary, and if required, would impose costs which are disproportionately high compared to the benefits of reducing the estimated current risks. ${ }^{259}$

251. See Morrall, supra note 1 , at 30 tbl.4.

252. It is also worth noting that before Morrall prepared his 1986 table on regulatory costs and before EPA issued a final standard on low-arsenic copper smelters, OMB had expressed its opinion on the proposed standard. OMB estimated that regulating arsenic emissions at the ASARCO-El Paso facility-the only facility regulated by the standard that appears on Morrall's list-would cost $\$ 7$ million per fatal cancer prevented, a figure two orders of magnitude below Morrall's own estimate. See OMB Posifion, supra note 160 , at 1600 tbl.V.

253. See Standards for Inorganic Arsenic, 51 Fed. Reg. at 27,959. 1 refer throughout to the "arsenic/glass plant" rule. As noted above, see supra Subsection II.A.2.c. Morrall also lists a 1986 EPA rule, "arsenic/glass manufacturing," which he reports as rejected. There was only one 1986 rule regarding arsenic emissions from glass (manufacturing) plants, however, and this was the final rule discussed in the text. See supra Subsection II.A.2.c.

254. See Standards for Inorganic Arsenic, 51 Fed. Reg. at 27,959.

255. See id. at 27,993 .

256. See id.

257. See id. at 27,995 .

258. Id.

259. Id. at 27,997 . 
EPA wrote the new emission standard in such a way that, in practice, it would apply to only the two plants-in Martinsburg and Charleroi-at which it found that emission controls would be cost-justified. EPA expressed some concern that requiring controls at the Charleroi plant would lead the plant to close but noted that representatives of the plant had stated that they planned to discontinue producing arsenic-containing glass. ${ }^{260}$

Thus, based on an analysis of risks, costs, and technological feasibility, EPA ultimately (again) produced a nationwide emissions standard that in practice required controls at only one facility in the country. ${ }^{261}$ If one were to review only EPA's explanation of its new standard and of its rejection of further controls, one would be likely to conclude that this explanation reflects exactly the kind of analysis the regulatory reformers want to precede regulatory decisions-an analysis sensitive to site-specific costs, to technological constraints, and to the relationship between costs imposed and benefits produced. $^{262}$

Despite this attention to costs and benefits, Morrall reports that the rule still ended up costing $\$ 19.2$ million per life saved. ${ }^{263}$ Many observers have placed this rule in the "failing" portion of Morrall's list because they regard $\$ 19$ million as too much to spend to save a life. ${ }^{26 s}$ Again, however, this estimate departs notably from the agency's. Morrall reports that the rule responded to an initial annual risk of 8 in 10,000 and that it would save 0.11 lives per year. ${ }^{265}$ EPA reported identical risk estimates for the Martinsburg glass plant (the only plant expected to implement new controls as a result of the rule). ${ }^{266}$ EPA also reported that the costs of controlling arsenic emissions at this plant would amount to $\$ 533,000$ in annualized costs. ${ }^{267}$ Multiplying these annualized costs by nine (to arrive at the costs associated with saving one life in nine years) results in a cost per life saved of approximately $\$ 4,797,000,{ }^{268}$ a number far below the $\$ 19.2$ million per life saved that Morrall reports. Again, therefore, discounting appears to play a critical role in Morrall's estimates of costs per life saved.

260. See id.

261. Again, therefore, the costs reported in Morrall's table are effectively incremental costs.

262. OMB during the Reagan years suggested this approach. See supra note 246 and accompanying text.

263. See Morrall, supra note 1 , at 30 tbl.4.

264. See, e.g., VISCUSI, supra note 2, at 264 tbl.14-5; Lutler \& Morrall, supra note 2, at 59; Sunstein, Health-Health Tradeoffs, supra note 2, at 1547-48 tbl.2.

265. See Morrall, supra note 1, at 30 tbl.4.

266. See National Emissions Standards for Hazardous Air Pollutants: Standards for Inorganie Arsenic. 51 Fed. Reg. 27,956, 27,996 tbl.IV-4 (1980) (to be codified at 40 C.F.R. pt. 61) (estimating the initial annual risk as 8 in 10,000 and the number of lives saved per year as 0.11 ).

267. See id. at 27,995 tbl.IV-3.

268. As just noted, both Morrall and EPA estimated that the rule will save 0.11 lives per year. This is the same as estimating that one life will be saved every nine years, at an annualized cost of \$533.000. Multiplying $\$ 533,000$ by nine yields a cost per life saved of $\$ 4,797,000$. 


\section{d. Asbestos (OSHA 1986)}

In 1986, OSHA tightened the standards for workplace exposure to asbestos that it had set in $1972 .{ }^{269}$ Morrall estimated that the 1986 rule on asbestos would save 74.70 lives per year, at a cost of $\$ 89.3$ million apiece. ${ }^{270}$ OSHA calculated that the rule would save 74.72 lives per year from cancer alone at a cost of $\$ 6.09$ million apiece. ${ }^{271}$ This figure does not include the noncancer illnesses prevented by the rule, such as asbestosis, or the rule's prevention of disease in groups indirectly exposed to asbestos. ${ }^{272}$ Since Morrall did not adjust the agency's cost estimates, and since Morrall's and OSHA's estimates of annual lives saved are virtually identical, the difference in estimates of costs per life saved can, again, only be attributable to discounting. ${ }^{273}$

\section{e. Summary}

In each of these cases, a great discrepancy exists between the agency's estimate of costs per life saved and Morrall's. The difference is caused not by different predictions regarding the compliance costs of, or risks avoided by, the rule but instead stems from Morrall's decision to discount future lives saved by ten percent per year. Leaving aside for now whether this decision is justifiable, ${ }^{274}$ we have seen that it profoundly affects estimates of regulatory cost-effectiveness. ${ }^{275}$

269. See Occupational Exposure to Asbestos, Tremolite, Anthophyllite, and Actinolite, 51 Fed. Reg. 22,612 (1986) (to be codified at 29 C.F.R. pts. 1910, 1926). For a discussion of OSHA's 1972 rule on asbestos, see supra Subsection II.B.1.a.

270. See Morrall, supra note 1 , at 30 tbl.4.

271. See Occupational Exposure to Asbestos, Tremolite, Anthophyllite, and Actinolite, 51 Fed. Reg. at 22,666 tbl.25 (stating an expectation to save 74.72 lives per year at a net cost of $\$ 455.2$ million per year). The figure in the text was determined by dividing $\$ 455.2$ million by 74.72 , resulting in a cost estimate of $\$ 6.09$ million per life saved.

272. See id. at 22,666.

273. In a 1994 update to his 1986 table, Morrall reports that OSHA's 1986 asbestos regulation cost $\$ 2.8$ million per life saved, reflecting a decrease of more than $\$ 85$ million from the 1986 list. See Lutter \& Morrall, supra note 2, at 59 tbl.6. In his article containing the updated table, Morrall does not discuss this change. He has told me, however, that he lowered the estimate of costs per life saved on the basis of new epidemiological studies, which concluded that the risks from asbestos were higher than had been previously estimated. Telephone Interview with John F. Morrall III, Chief, Human Resources and Housing Branch, Office of Information and Regulatory Affairs, Office of Management and Budget (July 17, 1997). Perhaps this also explains why Morrall's estimate of the costs per life saved of EPA's 1986 asbestos ban dropped from $\$ 104.2$ million in 1986 to $\$ 72.9$ million in his updated 1994 table. Compare Morrall, supra note 1, at 30 tbl.4, with Lutter \& Morrall, supra note 2, at 59 tbl.6.

274. See infra Subsection III.A.1 for a discussion of this issue.

275. It is thus not surprising that Robert Hahn's recent effort to identify the costs per life saved of various federal regulations reports results similar to Morrall's, as Hahn's figures, too, reflect discounting of future benefits. See Robert W. Hahn, Regulatory Reform: What Do the Government's Numbers Tell Us?, in RISKS, COSTS, AND LIVES SAVED 208, 248 n.4l (Robert W. Hahn ed., 1996). 


\section{Estimating Risks}

In several cases, Morrall not only discounted future lives but also adjusted-inevitably downward-the agencies' estimates of actual risk. In this subsection, I discuss the rules whose cost profiles were affected by Morrall's new risk estimates, again focusing on the bottom half of the list. Because the quantified benefits of these rules were dominated by the prevention of cancer ${ }^{276}$ - a benefit presumed to occur in the future rather than immediately-Morrall's estimates of the costs per life saved by these regulations were, like the estimates discussed in the preceding section, greatly increased by his application of a ten percent annual discount rate to the agencies' estimates of the number of lives saved. As to this group of rules, however, Morrall's cost estimates were also increased due to his use of risk estimates very different from those the agencies used. ${ }^{277}$

\section{a. Formaldehyde (OSHA 1985)}

In 1985, OSHA proposed a rule limiting occupational exposure to formaldehyde. ${ }^{278}$ Among other things, the agency proposed a PEL of 1.0 ppm. ${ }^{279}$ This regulation was proposed at the time Morrall compiled his original list; it became final in $1987 . .^{280}$ OSHA estimated that its final regulation would cost a total of $\$ 64.2$ million per year. ${ }^{281}$ For the industries in which existing exposures to formaldehyde were above the proposed limits, OSHA estimated that the annualized cost of the rule would be $\$ 28.9$ million. ${ }^{282}$ The agency also estimated, "for illustrative purposes," that, in the industries just mentioned, the regulation would save between 6.5 and 47.5 lives that would have been lost to cancer over a forty-five-year exposure period. ${ }^{233}$ Finally, the agency reported that the rule would produce annual monetary

276. Indeed, the quantified life-saving benefits of all but two of the nules discussed in this subsection include only the prevention of human cancer. The exceptions are EPA's land disposal ban. see Hazardous Waste Management System: Land Disposal Restrictions, 51 Fed. Reg. 44.714. 44.738 (1986) (to be codified at 40 C.F.R. pts. 260-62, 264-65, 268, 270-71) (proposed Dec. 11, 1986), and OSHA's benzene rule, see Occupational Exposure to Benzene, $50 \mathrm{Fed}$. Reg. 50,512, 50.541 (1985) (10 be codified at 29 C.F.R. pt. 1910) (proposed Dec. 10, 1985).

277. See also supra note 163 (discussing the large disparities between Morrall's and OSHA's estumates of risks from $\mathrm{EDB}$ ).

278. See Occupational Exposure to Formaldehyde, 50 Fed. Reg. 50.412 (1985) (10 be codified at 29 C.F.R. pt. 1910) (proposed Dec. 10, 1985).

279. See id.

280. See Occupational Exposure to Formaldehyde, 52 Fed. Reg. 46.168 (1987) (codsfied at 29 C.F.R. pts. 1910, 1926).

281. See id. at 46,241 .

282. See id. at 46,238 .

283. Id. at 46,241 . This estimate differs only slightly from OSHA's estumale at the tume the rule was proposed that the rule would prevent from 6 to 52 cases of cancer. See Occupational Exposure to Formaldehyde, 50 Fed. Reg. at 50,464. 
benefits of approximately $\$ 41.2$ million (reflecting cost savings due to avoided cases of respiratory irritation and dermatitis). ${ }^{284}$

Thus, based on OSHA's figures, the final rule cost approximately $\$ 21.8$ to $\$ 159.1$ million per quantified cancer case avoided ${ }^{285}$ Morrall, for his part, asserts that the proposed rule cost a stunning $\$ 72$ billion per life saved. ${ }^{286} \mathrm{I}$ first attempt to explain the basis for Morrall's estimates of the cost per life saved of this rule and then offer a critical perspective on the agency's own estimates.

What accounts for the large difference between OSHA's and Morrall's estimates of costs per life saved? A large part of the difference must be due to discounting. But in this case, differing estimates of risk also explain some part of the difference. Whereas OSHA estimated that at least six and possibly as many as forty-seven lives (or about one life, on average, per year) would be saved due to the rule over a forty-five year period, Morrall concludes that the rule would save only one life in 100 years. ${ }^{287}$ Morrall does not explain how he arrived at an estimate of risk so different from the agency's, other than to say that on several occasions he adopted estimates that "appeared to reflect prevailing scientific views more accurately than the agency estimate."288

There is good reason to believe, however, that Morrall's estimates of risks and costs came straight from OMB's controversial review of the formaldehyde rule. In evaluating the rule, three OMB economists took issue with the risk assessment performed by OSHA's scientific team (which included an epidemiologist, a toxicologist, an industrial hygienist, and a biochemist). Using different statistical methods from OSHA, the OMB economists concluded that formaldehyde was merely an "irritant" and that OSHA's rule would cost $\$ 72$ billion per life saved-the same figure used by Morrall. ${ }^{289}$ As one critic of OMB's review put it: "I am not aware that OMB has expertise in biology, epidemiology and toxicology, which are necessary for risk assessments." ${ }^{290}$

284. See Occupational Exposure to Formaldehyde, 52 Fed. Reg. at $46,241-42$.

285. These figures were derived by first subtracting total annual monetized benefits ( $\$ 41.2$ million) from total annual costs ( $\$ 64.2$ million), to reach a net annual cost of $\$ 23$ million; the latter figure was multiplied by 45 (to account for the 45 -year study period), and divided by the estimated number of lives saved (6.5 or 47.5 ). Note that my assumption that this rule will continue to impose onerous costs for 45 years probably greatly overstates the costs of the rule, as the engineering controls used to comply with the rule likely will have been installed within the first few years of the rule's operation.

286. See Morrall, supra note 1, at 30 tbl.4. Updated versions of Morrall's list refer to OSHA's final rule and report that the rule cost more than $\$ 86$ billion per life saved (in 1990 dollars). See, e.g., BREYER, supra note 2 , at $26-27$ tbl.5.

287. He reports that there are 0.01 lives saved annually by the nule. See Morrall, supra note 1, at 30 tbl.4.

288. Id. at 28-29. Morrall's very high estimate of the costs per life saved of this rule is also duc in part to the fact that his estimate reflects incremental costs rather than average costs. Telephone Interview with John F. Morrall III, supra note 273; see also supra note 160 (discussing the relationship between incremental and average costs).

289. See Judith Havemann, Assessed Cancer Risk Is Inflated, OMB Says Regulatory Agencies May Get Guidelines, WASH. POST, July 13, 1986, at A8.

290. Id. (quoting Dr. Frederica Perera, then-Assistant Professor of Public Health, Columbia University). 
The deputy director of OSHA's Health Standards Directorate later testified about his experience dealing with $\mathrm{OMB}$ :

[T]he comments we get from the economists at OMB are so ridiculous that they actually become funny. . . An example is that Dr. Infante and Dr. Rodgers and I met with two economists from OMB and discussed the health hazards of formaldehyde with them, and they adamantly argued with us about the toxicity of formaldehyde. Dr. Infante had to give them an epidemiology lesson, and Dr. Rodgers had to give them a toxicology lesson, and I had to describe how to do risk assessments for them. ${ }^{291}$

Morrall's deflation of OSHA's estimate of the risks of formaldehyde is all the more striking when one considers the evidence that even OSHA's estimate of risk was too low. OSHA was dragged kicking and screaming through every step of the formaldehyde rulemaking. ${ }^{292}$ When, in the middle of this process, new studies appeared that indicated that formaldehyde posed higher risks than had been previously estimated, ${ }^{293}$ OSHA effectively neutralized the studies' impact by departing from usual practice and presenting a range of risk estimates rather than "best estimates."294 In another break from usual practice, OSHA also relied most heavily on a risk estimate that incorporated a nonlinear dose-response relationship at low exposures, notwithstanding the fact that the agency had acknowledged that use of a linear dose-response curve was appropriate when synergistic effects were suspected and that formaldehyde might act synergistically with other chemicals in causing cancer. ${ }^{295}$ The D.C. Circuit ultimately overturned the rule on this basis, concluding that although "OSHA acknowledged the truth of facts that appear[ed] to compel it to assume linearity at low doses in its risk assessments," it then either "discard[ed] the resulting estimates or at least [gave] them comparatively scant weight."296

OSHA derived its highest estimate of lives saved-47.5, over a forty-five year period-by using a linear dose-response curve. ${ }^{297}$ Use of this curve was.

291. Oversight of the Occupational Safery and Health Adminustrotton: Hearngs Before the Comm. on Labor and Human Resources, 100th Cong. 513-14 (1988) (statement of John Martonik. Deputy Director. Health Standards Directorate, Occupational Safety \& Health Admin.): see also MCGARTr \& SHAPIRO. supra note 91 , at 110 .

292. See MCGARTTY \& SHAPIRO, supra note 91, at 87-89. 108-11. 159-61.

293. See id. at 109-10.

294. Id. at 110.

295. See Intemational Union, UAW v. Pendergrass, 878 F.2d 389. 395 (D.C. Cir. 1989).

296. Id. at 396. The cour remanded the case to the agency for either a better explanation or a new risk estimate. On remand, OSHA lowered the exposure limit it had initially proposed to $0.75 \mathrm{ppm}$. See Occupational Exposure to Formaldehyde, 57 Fed. Reg. 22,290. 22,290 (1992) (to be codified at 29 C.F.R. 1910). It stated that it was unable to quantify the difference in risk posed by the $1.0 \mathrm{ppm}$ standard and the $0.75 \mathrm{ppm}$ standard but explained that the lower standard was chosen in order to ensure safety. See id. at 22,305

297. See Occupational Exposure to Formaldehyde. 52 Fed. Reg. 46,168, 46,242 tbl.8 (1987) (codified at 29 C.F.R. pts. 1910, 1926). This estimate is based on the assumption of lineanty al low doses. See Pendergrass, 878 F.2d at 395. 
as just noted, consistent with the agency's acknowledgement of formaldehyde's synergistic potential. Thus, the agency's highest estimate of lives saved appears to be more reliable than the lowest estimate, given all the facts. This, in turn, implies that the low estimate of cost, $\$ 21.8$ million per life saved, is closer to the mark than the high estimate, $\$ 159.1$ million per life saved. Recall, too, that OSHA's estimate of the lives saved by the rule pertained only to the industries where formaldehyde exposures exceeded the exposures allowed by the new standard. ${ }^{298}$ The annualized costs of compliance for these industries were estimated to be $\$ 28.9$ million, or less than half the total annualized costs of the rule. ${ }^{299}$ If one assumed that most of the monetized annual benefits of the rule (\$41.2 million in cost savings due to avoided cases of respiratory irritation and dermatitis) ${ }^{300}$ were from these industries, where exposures were highest, then one could report that this rule saved workers in these industries from cancer at a negative net cost. This would be a misleadingly positive account of the rule, however, given that the rule also imposed over $\$ 30$ million in annual costs on other industries, for an uncertain, and perhaps trivial, life-saving return.

\section{b. Land Disposal (EPA 1986)}

By the early 1980 s, federal laws were in place that limited the discharge of pollution into the air and water. ${ }^{301}$ Some of these restrictions had worked in part by simply shifting pollution from these media onto the land. It had also become clear by this time that all landfills, however well designed, would eventually leak, ${ }^{302}$ and early experience with the Superfund law $^{303}$ had begun to reveal how expensive and time-consuming the cleanup of contaminated land would be.

In recognition of these facts, Congress in 1984 severely limited the disposal on land of hazardous wastes. ${ }^{304}$ Known as the "land disposal ban," the legislation required that hazardous waste be treated prior to land disposal or that there be a showing that the waste, if disposed of on land, would not migrate during the period it remained hazardous. ${ }^{305}$ The law directed EPA

298. See supra text accompanying notes 282-283.

299. See Occupational Exposure to Formaldehyde, 52 Fed. Reg. at 46,238 tbl.6 (breaking down compliance costs by industry).

300. See id. at $46,241-42$.

301. These laws included, most prominently, the Clean Air Act, 42 U.S.C. \$\$ 7401-7671 (1994), and the Clean Water Act, 33 U.S.C. \$§ 1251-1387 (1994).

302. See PERCIVAL ET AL., supra note 72, at 265.

303. Comprehensive Environmental Response, Compensation and Liability (Superfund) Act, 42 U.S.C. $\S \S 9601-9675$.

304. See Hazardous and Solid Waste Amendments of 1984, Pub. L. No. 98-616, 98 Stat. 3221 (codified at 42 U.S.C. $\$ 6924$ ).

305. See 42 U.S.C. $\S 6924(\mathrm{~d})(1),(\mathrm{e})(1),(\mathrm{g})(5),(\mathrm{m})$. 
to promulgate rules implementing these requirements in stages. ${ }^{306}$ One of EPA's sets of proposed regulations implementing the land disposal restrictions is the 1986 "land disposal" regulation appearing on Morrall's list. ${ }^{307}$ This regulation applied to the so-called "California List" wastes, which included such hazardous wastes as polychlorinated biphenyls (PCBs), cyanides, certain highly corrosive wastes, and wastes containing metals (such as arsenic, lead, and mercury) above a specified concentration. ${ }^{308}$

Morrall reports that this regulation saves 2.5 lives annually at a cost of $\$ 3.5$ billion per life saved. ${ }^{309}$ These figures differ dramatically from those offered by EPA in support of its proposed rule. The agency estimated that the annualized costs of the rule would be approximately $\$ 97$ million. ${ }^{310}$ The agency also estimated that the rule would, over seventy years, prevent approximately 2853 "weighted cases" of cancer, fetal toxicity, decreases in reproductive capacity, and other adverse health effects. ${ }^{311}$ The rule would thus prevent about forty-one cases of adverse human health effects per year, at a cost of $\$ 2.38$ million per case avoided. ${ }^{312}$ Even taking into account the fact that some of the adverse health effects prevented by the rule are nonfatal, there is a vast spread between Morrall's risk estimates and the agency's. Indeed, given that Morrall himself concludes that the rule will save 2.5 lives annually, given his practice of accepting agency cost estimates without adjustment, and given the fact that the agency estimated the costs of this rule to be $\$ 97$ million per year, it is difficult to imagine how Morrall came up with a figure of $\$ 3.5$ billion per life saved. Certainly, however, a large part-if not all-of the spread between Morrall's estimates and the agency's estimates results from the combined effect of Morrall's lower risk estimates and his discounting of lives saved. ${ }^{313}$

306. See id. $\$ 6924(\mathrm{~d}),(\mathrm{e}),(\mathrm{g})$.

307. See Hazardous Waste Management System: Land Disposal Restrictions, 51 Fed. Reg. 44,714 (1986) (to be codified at 40 C.F.R. pts. 260-62, 264-65, 268, 270-71) (proposed Dec. 11. 1986).

308. See id. at 44,715. These were called "Califomia List" wastes because Caltforna had regulaled them and in so doing had determined the concentrations at which they could be safely disposed of on land. See Land Disposal Restrictions for Certain "California List" Hazardous Wastes and Modifications to the Framework, 52 Fed. Reg. 25,760, 25,761 (1987) (to be codified at 40 C.F.R. pts. 260-62, 264-65, 268, 270 71).

309. See Morrall, supra note 1 , at 30 tbl.4.

310. See Hazardous Waste Management System: Land Disposal Restnctions, SI Fed. Reg at 44,737.

311. Id. at 44,738 . These estimates did not include adverse environmental effects avorded by the rule. See id. at 44,737-38.

312. See id. at 44,738 .

313. Although only a proposal at the time Morrall prepared his initual list, the land disposal nule is now final. See Land Disposal Restrictions for Cerain "Califomsa List" Hazardous WWastes, 52 Fed. Reg. 25,760 (1987) (to be codified at 40 C.F.R. pts. 260-61, 262, 265, 268, 270-71). A challenge to the rule, brought by the Hazardous Waste Treatment Council, was dismissed for want of standing. See Hazardous Waste Treatment Council v. Thomas, 885 F.2d 918, 927 (D.C. Cir. 1989). 


\section{c. Uranium Mill Tailings (EPA 1983)}

In response to the Uranium Mill Tailings Radiation Control Act of $1978,{ }^{314} \mathrm{EPA}$ issued rules providing for the stabilization, control, and cleanup of radioactive materials at active and inactive uranium processing sites. ${ }^{315}$ Uranium tailings piles are hazardous primarily because they create a risk of lung cancer (the tailings contain radium, which produces radon, which is a human carcinogen), and the hazard is long-lived: The radium in uranium tailings piles will take several hundred thousand years to decay to about ten percent of current levels. ${ }^{316}$

The uranium tailings statute does not give specific guidance as to the level of cleanup to be achieved. EPA decided to make it the agency's

objective to establish standards that take account of the tradeoffs between costs and benefits in a way that assures adequate protection of the public health, safety, and the environment; that can be implemented using presently available techniques and measuring instruments; and that are reasonable in terms of overall costs and benefits. ${ }^{317}$

Though the agency decided to set standards based on the relationship between costs and benefits, it acknowledged that a formal cost-benefit analysis was impossible in this context:

It was not possible to carry out a formal quantitative cost-benefit analysis to reach these conclusions. Many of the hazards reduced (or avoided) through application of alternative standards can neither be evaluated quantitatively nor restated in terms of a common index of value. The major hazard, the extent of possible future misuse of tailings by man, is almost impossible to quantify. A further complication is that the benefits of successful control accrue over a very long period of time, whereas the costs occur now. We can only roughly estimate how long control will last and how many cases of lung cancer might be avoided over the full term of effective control. $^{318}$

314. Pub. L. No. 95-604, 92 Stat. 3021 (codified as amended in scattered sections of 42 U.S.C.).

315. See Environmental Standards for Uranium and Thorium Mill Tailings at Licensed Commercial Processing Sites, 48 Fed. Reg. 45,926 (1983) (to be codified at 40 C.F.R. pt. 192).

316. See id. at $45,927-28$.

317. Standards for Remedial Actions at Inactive Uranium Processing Sites, 48 Fed. Reg. 590,590 (1983) (to be codified at 40 C.F.R. pt. 192).

318. Environmental Standards for Uranium and Thorium Mill Tailings at Licensed Commercial Processing Sites, 48 Fed. Reg. 19,584, 19,596-97 (1983) (to be codified at 40 C.F.R. pt. 192) (proposed Apr. 29, 1983). 
Despite these caveats, the agency did provide some rough numerical estimates of the costs and benefits of its rules. With respect to tailings at active uranium processing sites, the agency estimated that, without the rule, the tailings at all piles in existence at the time of the final rule would cause about 500 deaths from lung cancer over the course of a century. ${ }^{319}$ The agency predicted that additional tailings would raise the total number of deaths per century to about 600 by the year $2000.0^{320}$ EPA estimated total compliance costs of about $\$ 260$ million for all tailings in existence at the time of the final rule or $\$ 310$ million to $\$ 540$ million for tailings projected to be generated by the year $2000 .^{321}$ These estimates included costs borne as a result of other regulations and thus reflected "the upper bounds of cost and economic impact imposed by these standards." 322 The combination of risks and costs for tailings existing in 1983 (when the final rule was issued) yields a very rough estimate of approximately $\$ 520,000$ per life saved. EPA itself estimated that the costs per life saved, calculated only regionally and only over the next century, was $\$ 2.5$ million. ${ }^{323}$ This number dropped to $\$ 130,000$ per life saved if nationwide benefits, for 1000 years, were taken into account. ${ }^{324}$

Morrall reports that this regulation saves 2.1 lives per year at a cost of $\$ 53$ million per life saved. ${ }^{325}$ His figure on annual lives saved is less than half of EPA's, whose estimate of 500 lives saved in the first century translates to an average of five lives saved per year. Once again, then, Morrall's reporting of substantially higher-100 times higher-costs per life saved than the agency's (implicit) estimate must be attributed to a combination of different risk estimates and discounting.

With respect to the rule pertaining to tailings at inactive uranium processing sites, ${ }^{326}$ EPA again cautioned that a formal cost-benefit analysis was impossible in this context, given the uncertainties and lengthy periods of time involved in the rulemaking. ${ }^{327}$ Nevertheless, the agency did offer some rough estimates of costs and benefits. The agency estimated that its rule would save 200 lives over the course of a century, at a total cost of approximately $\$ 314$ million. ${ }^{328}$ This amounts to a cost of about $\$ 1.57$ million per life saved during the first century of the rule's effects. As the agency noted, however, the

319. See Environmental Standards for Uranium and Thonum Mill Talings at Licensed Commercial Processing Sites, 48 Fed. Reg. at $45,929$.

320. See id.

321. See id. at 45,945 .

322. Id.

323. See id. at $45,944-45$.

324. See id.

325. See Morrall, supra note 1. at 30 tbl.4.

326. See Standards for Remedial Actions at Inactive Uranium Processing Sites, 48 Fed. Reg. 590 (1983) (to be codified at 40 C.F.R. pt. 192).

327. See id. at 596.

328. See id. at 596-97. 
rule would also prevent "a total of many thousands" of deaths over the life of the control system required by the rule. ${ }^{329}$

Morrall reports that this regulation saves 2.1 lives per year at a cost of $\$ 27.6$ million per life saved. ${ }^{330}$ His figure on annual lives saved is very similar to EPA's, whose estimate of 200 lives saved in the first century translates to an average of two lives saved per year. Morrall's reporting of a substantially higher-twenty times higher-cost per life saved than the agency's (implicit) estimate must be attributed again to a combination of different risk estimates and discounting. Given the closeness of Morrall's risk estimates and those of the agency, however, the difference in cost estimates must in this case be due almost entirely to discounting.

\section{d. Coke Ovens (OSHA 1976)}

Citing a "significant risk of cancer to the exposed working population," OSHA in 1976 regulated emissions from coke ovens. ${ }^{331}$ Because this rule was issued before OSHA began quantifying the lives that would be saved by its health regulations, ${ }^{332}$ it is not possible to compare Morrall's 1986 estimates of risks and costs with the agency's. In 1983, however, Broder and Morrall estimated that this rule would save 35.4 lives per year at a cost of $\$ 4.5$ million per life saved. ${ }^{333}$ In 1986 , Morrall figured the same rule would save thirty-one lives per year at a cost of $\$ 61.8$ million per life saved. ${ }^{334}$ Some of the difference in cost estimates is attributable to the different estimates of lives saved (35.4 versus 31), but this difference (amounting to less than one-tenth of the earlier estimate of lives saved) cannot explain the more than ten-fold difference in costs cited by the two sources. Discounting appears mostly responsible for the fantastic cost estimates cited by Morrall in 1986, as compared to the estimates Broder and Morrall reported in 1983.

The 1983 estimate that the coke oven rule would save 35.4 lives, at a cost of $\$ 4.5$ million each, appears to have been drawn directly from Morrall's 1976 statement in opposition to OSHA's proposed rule, offered on behalf of COWPS. ${ }^{335}$ In that statement, Morrall chided OSHA for refusing to engage in cost-benefit analysis and for refusing to assign a dollar value to human life. ${ }^{336} \mathrm{He}$ suggested that a more sensible way of reducing risks from coke

329. Id. at 597.

330. See Morrall, supra note $\mathrm{I}$, at $\mathbf{3 0}$ tbl.4.

331. Exposure to Coke Oven Emissions, 41 Fed. Reg. 46,742 (1976) (to be codified at 29 C.F.R. pt. 1910). OSHA also cited evidence that coke oven emissions were associated with nonmalignant respiratory diseases such as bronchitis, emphysema, and pneumoconiosis. See id. at $46,744,46,748$.

332. See supra note 232 and accompanying text.

333. See Broder \& Morrall, supra note 91, at 250 tbl.15.2.

334. See Morrall, supra note 1 , at 30 tbl.4.

335. See Exposure to Coke Oven Emissions, supra note 213, at 10-12.

336. See id. at 5-6. 
oven emissions might be simply to "rotate out" workers after five years on the job. ${ }^{337} \mathrm{He}$ estimated that OSHA's proposed rule would save from eight to thirty-five lives each year, at a cost of $\$ 4.5$ million to $\$ 158$ million apiece. ${ }^{338}$ In an article written in 1978, he opined that the same rule would cost from $\$ 9$ million to $\$ 48$ million per life saved, depending on which risk estimate was used. $^{339}$

Morrall's various estimates of the risk of coke oven emissions differ dramatically from some of the estimates that emerged during OSHA's rulemaking. In its explanation of the final standard, OSHA observed that the rulemaking record contained widely varying estimates of the number of lives that would be saved every year by the rule. ${ }^{340}$ These included COWPS's estimate that the rule would save between eight and thirty-five lives per year, and the very different estimate, contained in the Inflation Impact Statement (IIS), of 240 lives saved yearly by the rule. ${ }^{341}$ OSHA took issue with some of the assumptions of COWPS's analysis; in particular, it noted that COWPS had underestimated the exposed population by approximately forty percent and had used a risk factor for coke oven workers that actually reflected the (lower) risk factor for coke plant workers. ${ }^{342}$ As for the IIS estimate, OSHA noted that if one accounted for likely deaths from competing causes over the assumed period of exposure, the IIS estimate of lives saved would drop to $211 .^{343}$ The IIS's estimate of 240 lives saved, even adjusted downward to 211 as OSHA suggested, is much higher than Morrall's 1986 estimate of 31 annual lives saved. ${ }^{344}$ If one accepted the adjusted IIS figure of 211 annual lives saved and COWPS's "best guess" of around $\$ 200$ million in annual costs, ${ }^{345}$ the cost per life saved of this regulation would be less than $\$ 1$ million-or over $\$ 60$ million less per life saved than Morrall estimated in 1986.

It is worth stressing that OSHA itself did not believe it was capable of providing a meaningful estimate of the number of lives that would be saved by this regulation. OSHA could not say, for example, whether the new standard would eliminate all mortality from coke oven emissions; ${ }^{3+6}$ it could not quantify the decreases in mortality that would result indirectly from the

337. Id. at $8,12$.

338. See id. at tbl.D.

339. See John F. Morrall III, OSHA and U.S. IndusIry. in ECONOMIC EFFECTS OF GOVERNMEST. MANDATED COSTS 70, 77 n.35 (Rober F. Lanzilloti ed., 1978).

340. See Exposure to Coke Oven Emissions, 41 Fed. Reg. 46,742. 46,750 (1976) (Io be codified at 29 C.F.R. pt. 1910).

341. See id.

342. See id.

343. See id.

344. The upper limit of COWPS's range of estimales is, however, vinually the same number (35) as that reported by Broder and Morrall in 1983 (35.4). See Broder \& Morrall. supra note 91, at 250 tbl.15.2.

345. Exposure to Coke Oven Emissions, 41 Fed. Reg. at $46,749$.

346. See id. at 46,750 . 
rule (such as those caused by increased medical surveillance and improved hygiene facilities); ${ }^{347}$ and it could not quantify the lives saved in the general population in surrounding communities due to the new rule. ${ }^{348}$ Moreover, the agency believed that the task of quantifying the benefits of the rule was greatly complicated by the long latency periods involved in the occupational health hazards (such as cancer) associated with coke oven emissions. ${ }^{349}$ On the last point, OSHA concluded that,

unless exposures are reduced now, we believe the mortality rate will not decline, and coke oven workers will continue to suffer the excess mortality of the past. In our view, the final rule provides immediate benefits relating to mortality by protecting employees today so that their mortality will be significantly reduced in the future. ${ }^{350}$

And, pressed by COWPS to identify the monetary value of a human life, OSHA demurred: "[T] here are so many difficulties involved in attempting to assign a dollar value to the benefits of the standard that such figures would not provide a meaningful indication of the true value of the standard." ${ }^{331}$

\section{e. Ethylene Oxide (OSHA 1984)}

At the time of the rule limiting ethylene oxide (EtO) exposure in the workplace, ${ }^{352}$ EtO was one of the twenty-five most common chemicals in the United States. ${ }^{353}$ OSHA's rule established a PEL for EtO of $1.0 \mathrm{ppm}$, following a determination, "based on animal and human data, that exposure to EtO presents a carcinogenic, mutagenic, genotoxic, reproductive, neurologic and sensitization hazard to workers. ${ }^{354}$ In determining the cancer risks posed by EtO, OSHA relied on three epidemiological studies in populations of workers exposed to EtO and on two studies showing carcinogenic effects in rats and monkeys. ${ }^{355}$ One of the rat studies supplied the experimental database for OSHA's quantitative risk assessment (that is, the numerical estimates of lives saved by the rule were derived by applying an extrapolation model to the data from this study). ${ }^{356}$

347. See id.

348. See id. at 46,751 .

349. See id. at 46,750 .

350. Id. at 46,750-51.

351. Id. at 46,750 .

352. See Occupational Exposure to Ethylene Oxide, 49 Fed. Reg. 25,734 (1984) (to be codified at 29

C.F.R. pt. 1910).

353. See id. at 25,734 .

354. Id.

355. See id. at $25,740-42$.

356. See Public Citizen Health Research Group v. Tyson, 796 F.2d 1479, 1496 (D.C. Cir. 1986). 
In estimating the costs per life saved of this rule, Morrall reports that he chose to rely on EPA's estimates of risk instead of on OSHA's because EPA's were based on epidemiological data rather than on animal studies. ${ }^{357}$ This choice likely made a significant difference in Morrall's estimates of costs per life saved. Before comparing Morrall's estimates of risk with OSHA's, however, it is worth pausing over the oddity of Morrall's suggestion that only the epidemiological studies were reliable in this case. The validity of, and conclusions to be drawn from, these studies were hotly contested in OSHA's rulemaking proceedings. The author of one of the studies testified that his study should be regarded as negative evidence of EtO's carcinogenicity. ${ }^{338}$ Others testified that this study was inconclusive rather than negative as to leukemia risk but that it clearly showed a connection between $\mathrm{EtO}$ and other cancers (pancreatic cancer and Hodgkin's disease). ${ }^{39}$ As for the other epidemiological studies, some commentators thought that they overstated risk because the workers in the studies were exposed to other chemicals in addition to EtO or that they were invalid because of their small sample size. ${ }^{360}$ Despite these criticisms, OSHA found that the epidemiological evidence, "although not by itself conclusive, [was] supportive of ElO's potential carcinogenic . . . effects.",361

Moreover, in line with a large scientific consensus that the results of animal studies are scientifically reliable indicators of risks to human health, ${ }^{362}$ OSHA also relied on the studies in experimental animals showing increased cancer risks from EtO. Its ultimate judgment was based on an assessment of all the evidence on the health risks of EtO, evidence from both human and animal studies. ${ }^{363}$

Thus, in implying that only the human epidemiological studies in this case were worthy of consideration, Morrall chose studies that the agency itself admitted were methodologically flawed and suggestive rather than probative of cancer risks. In discarding the results of the animal studies, Morrall-an economist, not a scientist-also appears to have dismissed the vast scientific

357. See Morrall, supra note 1, at 29.

358. See Public Citizen Health Research Group. 796 F.2d at 1487.

359. See id.

360. See id.

361. Occupational Exposure to Ethylene Oxide, 49 Fed. Reg. 25.734. 25.740 (1984) (to be codıfied at 29 C.F.R. pt. 1910).

362. For a general discussion of the relevance of animal studies to regulatory decisionmaking. sec. for example, Proposed Guidelines for Carcinogen Risk Assessment, 61 Fed. Reg. 17.960. 17.967 (Environmental Protection Agency 1986) (proposed Apr. 23. 1996).

363. In upholding OSHA's long-term exposure limit for ethylene oxide, the D.C. Circuit coneluded that OSHA's findings on risk-including those based on animal studies-were "based on evidence submitted by a significant portion of the scientific community." Public Cirizen Healsh Research Group. 796 F.2d at 1501 . 
consensus that cancer risks in animals are relevant to determining cancer risks in humans, even where epidemiological studies are available. ${ }^{364}$

Strangest of all, EPA itself relied on animal studies in assessing the risks of ethylene oxide. The agency criticized the human epidemiological studies available for ethylene oxide, ${ }^{365}$ and its quantitative estimates of the incremental risks of ethylene oxide were based exclusively on animal studies. ${ }^{366}$ Perhaps not surprisingly, therefore, Morrall's estimate of an individual risk of 4.4 in $100,000^{367}$ does not jibe with EPA's estimates of the risks of ethylene oxide. ${ }^{368}$ It remains a mystery why Morrall believes that EPA relied only on epidemiological studies and also a mystery where he obtained his figures on the risks of ethylene oxide.

Whatever the source, Morrall estimates that the ethylene oxide rule saves 2.8 lives per year at a cost of $\$ 25.6$ million apiece. ${ }^{369}$ OSHA's figures on risks and costs are very different. OSHA estimated that its standard would prevent from 457 to 871 excess cases of cancer over a fifty-year period ${ }^{370}$ at a cost of approximately $\$ 35.45$ million per year. ${ }^{371}$ Considering cancer alone, this works out to a cost per life saved of between $\$ 2.03$ million and $\$ 3.88$ million. $^{372}$ These estimates are more than $\$ 20$ million lower than Morrall's estimates of costs per life saved. Moreover, OSHA did not find that ethylene oxide posed only a risk of cancer. The agency also concluded that this chemical posed "a serious and significant risk of adverse health effects going well beyond those of an excess risk of cancer," such as increased risk of spontaneous abortion, fetotoxicity, decreased fertility, decreased sperm count

364. For one of many discussions of the difficulties in obtaining adequate epidemiological data, sce COMMITTEE ON RISK ASSESSMENT OF HAZARDOUS AIR POLLUTANTS, NATIONAL RESEARCH COUNCIL, SCIENCE AND JUDGMENT IN RISK ASSESSMENT 57-58 (1994)

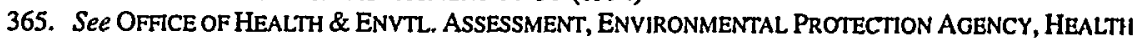
ASSESSMENT DOCUMENT FOR ETHYLENE OXIDE, FINAL REPORT, NO. EPA-600/8-84-009F, at 9-118 to -136 (1985).

366. See id. at 9-160, 9-168 to -169 .

367. See Morrall, supra note 1 , at 30 tbl.4.

368. See OFFICE OF HEALTH \& ENVTL. ASSESSMENT, supra note 365 , at 9-169 (providing the upperbound estimates of risks of 3.5 in 10 and 1 in 10,000, based on different studies).

369. See Morrall, supra note 1 , at 30 tbl.4. OMB, in contrast, estimated that the rule cost $\$ 60$ million per life saved. See 1986-1987 OMB REPORT, supra note 87, at xxi; 1987-1988 OMB REPORT, supra note 3 , at $\mathrm{xx}$. Since both OMB and Morrall used a 10\% annual discount rate, and both adjusted OSHA's risk estimates in determining costs per life saved, see 1987-1988 OMB REPORT, supra note 3, at xxii, I do not know why OMB estimated that the rule would cost over twice as much as Morrall estimated. The disparity is especially curious in light of the fact that the 1987-1988 OMB report cites Morrall's 1986 article. See 1987-1988 OMB REPORT, supra note 3, at xx.

370. See Occupational Exposure to Ethylene Oxide, 49 Fed. Reg. 25,734, 25,768 (1984) (to be codified at 29 C.F.R. pt. 1910) (stating that the rule would reduce excess cancers from ethylene oxide from a range of 532 to 1017 to a range of 75 to 146 over the next 50 years-leading to a net savings of 457 to 871 lives).

371. See id. at 25,767 .

372. This estimate is based on undiscounted costs. OMB estimated that if costs were discounted but benefits were not, the ethylene oxide rule would cost between $\$ 500,000$ and $\$ 1$ million per life saved. See 1987-1988 OMB REPORT, supra note 3, at xxii. 
and motility, mutagenicity, and chromosomal aberrations. ${ }^{373}$ The agency could not, however, quantify these other risks. ${ }^{374}$ If it could have, the cost of the rule, in relation to its benefits, would have been even lower. Once again, a great discrepancy exists between Morrall's calculations and those of the relevant agency.

\section{f. Benzene (OSHA 1985)}

OSHA's benzene rule, ${ }^{375}$ proposed in 1985 , was issued on remand from the decision in Industrial Union Department, AFL-CIO v. American Petroleum Institute, ${ }^{376}$ in which the Supreme Court held that before OSHA issues a new standard for workplace toxins, the agency must first find that a significant risk exists, based on quantitative estimates where possible. ${ }^{37}$ OSHA's proposed permissible exposure limit after remand was identical to the standard the Supreme Court invalidated. ${ }^{378}$

OSHA thought that the $10.0 \mathrm{ppm}$ standard in existence at the time of this rulemaking led to a leukemia risk of between 44 and 152 in $1000 .^{379}$ OSHA noted that other estimates of risk in the record, some falling as low as 9 in 1000 , were "based on assumptions which are not well supported." 380 The agency estimated that its regulation would save a total of 822 lives over a fifty-year period: 571 saved from leukemia and 251 from aplastic anemia. ${ }^{381}$ The agency stressed, however, that it had not quantified all of the likely benefits of the rule, including decreases in adverse health conditions other than leukemia and aplastic anemia and improved health for employees who were exposed to benzene in circumstances not analyzed in the rulemaking proceeding. ${ }^{382}$ OSHA estimated that the annualized costs of the rule would be about $\$ 29$ million. ${ }^{383}$ Considering only the health benefits quantified by OSHA, the cost per life saved of this rule thus comes to less than $\$ 1.8$ million. ${ }^{384}$

373. Occupational Exposure to Ethylene Oxide, 49 Fed. Reg. at 25,766.

374. See id.

375. Occupational Exposure to Benzene, 50 Fed. Reg. 50.512 (1985) (10 be codufied at 29 C.F.R. pt. 1910) (proposed Dec. 10, 1985).

376. 448 U.S. 607 (1980) (plurality opinion).

377. See id. at 642, 652-53.

378. See Occupational Exposure to Benzene, 50 Fed. Reg. at 50.512. 50.515 (statung that both the invalidated and the proposed PELs were an eight-hour time-weighted average of $1.0 \mathrm{ppm}$ ).

379. See id. at 50,538-39.

380. Id. at 50,539 .

381. See id. at 50,541. This works out to an average of approximately 16.4 lives saved per year.

382. See id. at 50,529 .

383. See id. at 50,543-44.

384. As noted, the agency expected the rule to save 822 lives over a 50-year penod at a yearly cost of $\$ 29.04$ million. 
Morrall, on the other hand, reports that the initial annual risk from benzene was 8.8 in 10,000 and that the proposed rule would save 3.8 lives per year at a cost of $\$ 17.1$ million apiece. ${ }^{385}$ The discrepancy between OSHA's and Morrall's calculations must be attributable both to discounting and to Morrall's use of substantially lower estimates of risk.

Updated versions of Morrall's list often cite OSHA's final rule on benzene, ${ }^{386}$ which was issued in $1987 .{ }^{387}$ The costs per life saved for the final rule are reported to range from $\$ 17.1$ million (in 1984 dollars), ${ }^{388}$ which is identical to Morrall's estimate of the costs of the proposed rule, to $\$ 23.1$ million (in 1992 dollars). ${ }^{389}$ For its part, OSHA estimated that the annualized costs of the final rule would be $\$ 24$ million $^{390}$ and would save at least 322 lives every forty-five years (230 from leukemia and 92 from aplastic anemia and "other diseases of the blood and blood forming organs")." Thus, according to OSHA's figures, the final rule costs approximately $\$ 3.3$ million for every life saved, well below Morrall's calculations with respect to the proposed rule.

\section{g. Summary}

In determining the costs per life saved of the regulations discussed in this subsection, Morrall not only continued the practice of discounting future lives saved, but also used lower estimates of risk than did the agencies. These lower risk estimates led to higher costs per life saved and thus produced a markedly different picture of the cost-effectiveness of the regulations from that offered by the agencies.

\section{Conclusion}

As the foregoing analysis demonstrates, Morrall's figures on benefits and costs are starkly different from other reported estimates. As Table 3 shows, if one adopts either the agency's (often implicit) estimate of costs per life saved or the estimate offered by Morrall in other contexts, then in every case but two, one finds a cost per life saved of less than $\$ 5$ million. ${ }^{392}$ Only OSHA's

385. See Morrall, supra note 1 , at 30 tbl.4.

386. See Occupational Exposure to Benzene, 52 Fed. Reg. 34,460 (1987) (to be codified at 29 C.F.R. pt. 1910).

387. For examples of updated lists, see Sunstein, Health-Health Tradeoffs, supra note 2, at 1548; and Viscusi, supra note 2, at 1434-35.

388. See Viscusi, supra note 2, at 1434-35.

389. See Sunstein, Health-Health Tradeoffs, supra note 2, at 1548.

390. See Occupational Exposure to Benzene, 52 Fed. Reg. at 34,516.

391. Id. at 34,508 .

392. The following table compares my findings, discussed at length in this section, with respect to costs per life saved with the figures from Morrall's 1986 table. Numbers are rounded to the nearest ten thousand. 
formaldehyde and arsenic regulations reflect a higher cost per life saved. ${ }^{393}$ This means that, as to virtually every rule, the costs per life saved as calculated by sources other than Morrall's 1986 table are below the range of current estimates of the monetary value of a human life based on studies of wage premiums for risky jobs. A figure of about $\$ 9$ million is commonly reported

TABLE 3. COMPETING Estimates of the COSTS OF VARIOL'S Risk-Redicing REgULATIONS PER LIFE SAVED

\begin{tabular}{|c|c|c|}
\hline REGULATION & $\begin{array}{l}\text { MORRAL's } 1986 \text { COST } \\
\text { Estimate (THOUSANDS)* }\end{array}$ & 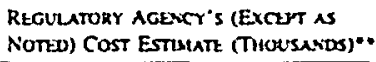 \\
\hline Asbestos (OSHA 1972) & 57400 & $\$ 190^{* \cdots *}$ \\
\hline Benzene (OSHA 1985) & 17.100 & 1800 \\
\hline Arsenie/Glass Plant (EPA 1986) & 19,200 & 4800 \\
\hline Ethylene Oxide (OSHA 1984) & 25.600 & 2030.3880 \\
\hline Uranium Mill Tailings/nactive (EPA 1983) & 27.600 & 1570 \\
\hline Acrylonitrile (OSHA 1978) & 37.600 & $3500 * \cdots$ \\
\hline Uranium Mill Tailings/Active (EPA 1983) & 53,000 & 2500 \\
\hline Coke Ovens (OSHA 1976) & 61.800 & $4500 \cdots$ \\
\hline Ashestos (OSHA 1986) & 89.300 & $2800 \cdots$ \\
\hline Arsenic (OSHA 1978) & 92,500 & $10.000 \cdots$ \\
\hline Arsenic/Low-Arsenic Copper (EPA 1986) & 764,000 & $\$ 170$ \\
\hline Land Disposal (EPA 1986) & $3.500,000$ & 2380 \\
\hline Formaldehyde (OSHA 1985) & $72,000,000$ & 21.800 \\
\hline
\end{tabular}

* Figures from Morrall, supra note 1, at 30 tbl.4. See also supra Table 1. These figures refleet a discount rate of ten percent for lives saved.

** These figures reflect a discount rate of zero.

*** Figures from Broder \& Morrall, supra note 91, at 250 \& tbl.15.2. The costs for the arsenic rule were cut roughly in half to reflect Morrall's doubling of his estumate of lives saved in his 1986 table. See supro Table 2. For the rules as to which OSHA did not quantufy lives sived. I have used Broder and Mlorrall's estimates of costs per life saved, even though they may overstate these costs by a large margin See supro note 239 and accompanying text; of. supra text accompanying notes 3.40-3.45 (discussing Broder and Morrall's higher estimates of costs per life saved as compared to OSHA's).

**** Figures from Lutter \& Morrall, supra note 2, at 59 tbl.6.

I have not included the 1979 Food and Drug Administration (FDA) rule regarding diethylsulbestrol (DES) in my calculations because I have been unable to locate any source documentung the nsks avoided and costs imposed by this rule (other than Morrall's own article). The FDA's decision effecuvely banned the use of DES to promote growth in cattle. See Chemical Compounds in Food-Producing Anmals. 44 Fed. Reg. 17,070 (1979) (to be codified at 21 C.F.R. pts. 70, 500, 514, 571) (proposed Mar. 20, 1979). The decision came under the infamous "Delaney Clause" of the Federal Food. Drug. and Cosmetuc Act. 21 U.S.C. $\$ 348(c)(3)(A)$ (1994), which bars the FDA from approving food addiuves that have been shown to cause cancer in humans or animals. For general discussion and cnticism, see Richard A Memll, FDA's Implementation of the Delaney Clause: Repudiation of Congressional Chorce or Reasoned Adapianon to Scientific Progress?, 5 YALE J. ON REG. 1, $25-29$ (1988). Because the Delaney Clause does not require the quantification of risk in order for a substance to be banned, the FDA did not provide any estumates of the number of lives saved by this regulation. See Chemical Compounds in Food-Producang Anumals. 44 Fed. Reg. at 17,070. I do not know where Morrall obtained his figures on risks and costs for this rule.

393. For reasons to think that the costs per life saved I am reporting for these rules are overstated, see supra notes 239. 285. 
today to be the preference-based value of life for nonmanual laborers; ${ }^{394}$ for manual laborers, it is much lower, around $\$ 2.5$ million. ${ }^{395}$ Another frequently cited range for the value of a human life is $\$ 3$ million to $\$ 7$ million. ${ }^{396}$ According to these estimates, therefore, all of these regulations save two pass even the test of cost-benefit analysis. ${ }^{397}$ (At least, that is, when applied to the richer among us. $)^{398}$ This is assuming what is in any event controversial, that the implicit valuation of risk found in studies of workers' wage premiums has meaningful implications for regulatory policy. ${ }^{399}$

394. See Shapiro \& McGarity, supra note 91 , at 735 n.38 (citing Alan Manin \& Gcorge Psacharopoulos, The Reward for Risk in the Labor Market: Evidence from the United Kingdom and a Reconciliation with Other Studies, 90 J. POL. ECON. 827 (1982)).

395. See id.

396. See, e.g., Hahn, supra note 275, at 216; Viscusi, supra note 2, at 1431; cf. Adam M. Finkel, A Second Opinion on an Environmental Misdiagnosis: The Risky Prescriptions of Breaking the Vicious Circle, 3 N.Y.U. ENVTL. L.J. 295, 319 (1994) (reporting that $\$ 10$ million per life saved is "within the range most economists would regard as reasonable").

397. This conclusion holds for all but three of the rules even when costs are adjusted for inflation. Note, however, that the estimates of the monetary value of a human life are based on studies done in the 1980 s and have not been adjusted for inflation. The following table reflects the costs per life saved reported supra note 392, as converted to 1995 dollars based on the consumer price index:

TABLE 4. REGULATORY AGENCY'S* COST ESTIMATES ADJUSTED FOR INFLATION

\begin{tabular}{||l|l||}
\hline REGULATON & ADJUSTED COST ESTMMATE (THOUSANDS Of 1995 DOLLARS) \\
\hline \hline Asbestos (OSHA 1972) & 5700 \\
\hline Benzene (OSHA 1985) & 2570 \\
\hline Arsenid/Glass Plant (EPA 1986) & 6610 \\
\hline Ethylene Oxide (OSHA 1984) & $3020-5780$ \\
\hline Uranium Mill Tailings/Inactive (EPA 1983) & 2410 \\
\hline Acrylonitrile (OSHA 1978) & 8570 \\
\hline Uranium Mill Tailings/Active (EPA 1983) & 3840 \\
\hline Coke Ovens (OSHA 1976) & 12,420 \\
\hline Asbestos (OSHA 1986) & 3860 \\
\hline Arsenic (OSHA 1978) & 24,490 \\
\hline Arsenic/Low-Arsenic Copper (EPA 1986) & 5740 \\
\hline Land Disposal (EPA 1986) & 3280 \\
\hline Formaldehyde (OSHA 1985) & 31,100 \\
\hline
\end{tabular}

* As noted supra Table 3, some of the estimates are not from the regulatory agency.

Source for conversions to 1995 dollars: U.S. DEP'T OF COMMERCE, STATISTICAL ABSTRACT OF THE UNITED STATES-1996, at 481 tbl.744 (1996).

398. Cf. W. Kip Viscusi, Equivalent Frames of Reference for Judging Risk Regulation Policies, 3 N.Y.U. ENVTL. L.J. 431, 447 (1994) ("[T]he United States Department of Transportation should want to place a higher value of life on the well-being of the lives of airline passengers than those killed in motorvehicle crashes because the airline passengers have a higher income.").

399. For an excellent discussion of the relevant issues, see Shapiro \& McGarity, supra note 91, at 73436. My alternative estimates of the costs per life saved of these health rules reduces not only the absolute level of regulatory costs but also the variability of regulatory costs found by Morrall. This is because discounting affects only those rules whose life-saving benefits are necessarily delayed, such as the health rules at the bottom of the list. 
If one also considers the unquantified benefits of these rules, including avoidance of human illness other than cancer, prevention of ecological harm, and damage to values such as autonomy, community, and equity, the case in favor of these regulations becomes clearer still. ${ }^{400}$ And this is all without any adjustment for the well-documented tendency of agencies and industry to overestimate greatly the costs of compliance with proposed regulation. ${ }^{401}$ Such overestimation has, in fact, been confirmed in retrospective studies of the compliance costs of some of the rules on Morrall's list. ${ }^{+02}$

In short, if one adopts Morrall's 1986 estimates of costs per life saved, one can paint a picture of a regulatory system out of control, with widely varying and astronomical costs per life saved. This picture makes possible the critiques of the current system charging that regulatory costs often exceed benefits; that regulations are often cost-ineffective; that health regulations are the worst offenders; that the system is a crazy quilt. The very high costs per life saved reflected in Morrall's table also take the pressure off proponents of cost-benefit analysis to identify when, exactly, it becomes too expensive to save a human life because the numbers reported by Morrall are asserted to be well beyond the range that could be considered reasonable. ${ }^{403}$

If, on the other hand, one adopts the agencies' estimates of costs per life saved, one sees a regulatory system in which these costs generally fall within a far narrower range and compare favorably to current estimates of the monetary value of a human life. One also sees a regulatory system striving to reduce risks to human health beyond those that can be quantified, risks to the environment, and risks to values that are widely shared. ${ }^{40 s}$

400. See infra Subsection III.A.3.

401. For a dramatic case of cost overestimation, see PERCIVAL ET $A L$, supra note 72, at 168-69, which states that the actual costs of the lead phase-out were $95 \%$ less than the oil industry's estimated costs.

402. See, e.g., MENDELOFF, supra note 91, at 57-59 (discussing retrospective studies of costs of OSHA standards).

403. Cf. W. Kip Viscusi, Occuparional Safery and Health in the 1990s, in THE SOC1AL. RESPONSE To ENVIRONMENTAL RISK: POLICY FORMULATION IN AN AGE OF UNCERTAINTY 187, 193 (Danicl IY. Bromley \& Kathleen Segerson eds., 1992) ("[I]t is not necessary to ascertain whether the appropnate value of life is $\$ 3$ million, $\$ 5$ million, or $\$ 7$ million. It is often sufficient to know that the value of life is in excess of $\$ 1$ million, yet falls considerably below a number such as $\$ 20$ million.").

404. The variability of estimates of the relationship beiween regulatory costs and benefits is also dramatically illustrated by another table that has made the rounds in the debate over regulatory reform. This table reports the costs per life-year saved of various life-saving interventions, which include nol only federal regulations but also medical procedures such as mammograms. See Tammy O. Tengs el al.. Five-Hundred Life-Saving Interventions and Their Cost-Effecfiveness. 15 RISK ANALYSIS 369 (1995). It is striking to notice how the cost per life-year saved of the very same regulatory strategy varies according to the source of the estimate. See, e.g., id. app. A at 375-76 (stating that the cost per life-year saved of a regulation pertaining to high-arsenic copper smelters ranges from $\$ 36,000$ (EPA's estımate) 10 574.000 (OMB's estimate), the cost per life-year saved of regulation of low-arsenıc copper smelters ranges from $\$ 2.6$ million to $\$ 890$ million, and the cost per life-year saved of regulation of arsenic emissions from glass plants manges from $\$ 2.3$ million to $\$ 51$ million); id. at 376 (stating that the cost of benzene control at rubber tire manufacturing plants is estimated to be $\$ 76,000$ or $\$ 20$ billion); id. at 377 (stating that the cost per life-year saved of a ban on urea-formaldehyde foam insulation in homes is either $\$ 11,000$ (EPA's estimale) or $\$ 220,000$ (Viscusi's estimate)). The figures from Tengs et al.'s table bear out my general point regarding Morrall's table: Such tables tell us more about the importance of the assumptions underlying numencal 
How can we choose between these two very different visions of the regulatory system?

\section{THE PERILS OF PRECISION}

This part argues that we can choose between the two different visions of the regulatory system I have sketched only by first making important and contested choices about values. As we have seen, Morrall reaches his conclusions about the costs of regulation by discounting lives saved, by adjusting the agencies' estimates of risk, and by considering only quantified human lives saved in tallying the benefits of regulation. Morrall's approach to calculating costs thus incorporates implicit assumptions about the relative worth of lives saved today and lives saved tomorrow, the appropriate response to scientific uncertainty, and the purposes of environmental law. His estimates of costs, in other words, grow out of choices about values. The regulatory reformers who have relied on Morrall's table in critiquing the current system thus err by thinking Morrall's numbers bring objectivity and clarity to a contentious and complicated subject. On the contrary, the embedding of values in this table of numbers disguises the numbers' true meaning and inhibits useful and informed discussion about the matters in question. Indeed, the numbers are derived from the very norms they have been thought to support.

So far, this is a familiar theme. Many other scholars have identified situations in which seemingly technocratic decisions mask fundamental choices about values. ${ }^{405}$ In arguing that John Morrall's calculations of regulatory costs are infused with values, I mostly cover ground staked out by others in different settings. But I eventually draw from this analysis a conclusion different from the one others have offered. I do not argue in favor of ever more complex and sophisticated methods of compressing the benefits of the regulatory state into one aggregated number, such as costs per life saved, but against such aggregation altogether.

\section{A. Numerical Values}

In this section, I discuss the values implicit in choices about discounting, the methodology of quantitative risk assessment, and the range of benefits to be considered in evaluating regulatory performance. I devote most of my attention to discounting, as this technique is responsible for such a large part

estimates of risks, costs, and benefits than they do about the wisdom of any given regulatory strategy. See infra Part III.

405. See, e.g., John D. GRAHAM ET AL., IN SEARCH OF SAFETY: CHEMICALS AND CANCER RISK (1988); Farber, supra note 90; Latin, supra note 109. For an extended discussion of this dynamic in environmental regulation, see Wendy E. Wagner, The Science Charade in Toxic Risk Regulation, 95 COLUM. L. REV. 1613 (1995). 
of the divergence between Morrall's and the agencies' estimates of regulatory costs. $^{406}$

\section{Discounting Lives}

Discounting is the calculation of the present value of a future cost or benefit. As applied to dollars invested in private projects, the concept of discounting is both easy to understand and uncontroversial. The premise of discounting dollars is that a dollar today is worth more than a dollar tomorrow: While one waits for tomorrow's dollar to arrive, today's dollar could be earning interest in the bank. In order to compare two investments that pay benefits over different periods of time, therefore, not only does one need a common currency (such as dollars), but one also needs to state that currency in common temporal terms. This leads to the idea of computing present value. The calculation of the present value of a sum of money is accomplished by applying a fixed discount rate to the sum of money one expects eventually to receive, over the period of time one must wait before one receives the money. ${ }^{407}$

As long as the value of a human life is measured in dollars, the justification for discounting remains as I have just described it. If lives are commensurate with dollars-the premise of the monetary valuation of human life-then there appears to be little reason to object, in principle, to the idea of discounting the monetary equivalent of a human life, just as there is little reason to object to the idea of discounting any future sum of money to present value. Indeed, discounting the monetary compensation for the loss of a human life has been done for a very long time in the context of tort awards. The value of future earnings-the typical measure of loss in a wrongful death action-is routinely discounted to present value to reflect the fact that the tor award may be invested. ${ }^{408}$ This is, indeed, the way discounting made its first appearance in the literature on risk regulation-as an adjustment to the dollar value of a life saved in the future rather than as an adjustment to the estimate of the number of lives saved. ${ }^{409}$

If, for whatever reason, one does not assign a monetary value to human life, the justification for discounting the benefits of health regulation is less

406. See supra Subsections II.B.1-2.

407. For basic explanations of discounting, see WILLAAM J. BAUMOL \& ALAN S. BLINDER. ECONOMICS: PRINCIPLES AND POLICY 386-87 (6th ed. 1994); MENELL \& STEWART, supra note 138, at 88. 92; Daniel A. Farber \& Paul A. Hemmersbaugh. The Shadow of the Furure: Discount Rates, Later Generations, and the Environment, 46 VAND. L. REV. 267, 277.79 (1993): and What Price Postenty?. ECONOMIST, Mar. 23, 1991, at 73. For a more technical, but thoroughly readable, discussion, see EDTTH STOKEY \& RICHARD ZECKHAUSER, A PRIMER FOR POLICY ANALYSIS 159.76 (1978).

408. See RICHARD A. POSNER, ECONOMIC ANALYSIS OF LAW 192-96 (4th ed. 1992).

409. See Broder \& Mortall, supra note 91, at 253; Albert L. Nichols. The Regulation of Aurbome Benzene, in INCENTIVES FOR ENVIRONMENTAL PROTECTION 145, 176-77 (Thomas C. Schelling ed., 1983). 
straightforward. Now the future benefit to be discounted is not dollars, but lives. And the premise of this discounting is not that today's dollar is worth more than tomorrow's, but that a life saved today is worth more than one saved tomorrow. ${ }^{410}$

From the statement of this premise, it seems obvious that the decision to discount lives saved in the future involves a choice about values, as to which reasonable people may disagree. ${ }^{411}$ Thus, it is also obvious that the numbers in Morrall's table, dependent as they are on his decision to discount future lives saved, are themselves based on a contestable choice about values. Reasonable people may thus disagree that the regulatory costs reported in Morrall's table are as high as he says they are, and they may disagree by orders of magnitude. But let me elaborate on the reasons that have been offered in favor of discounting lives, in case the presence of values in decisions about discounting is not as obvious as I think it is.

Some scholars who favor discounting nonetheless appear to reject the idea that the premise of discounting lives is that tomorrow's lives saved are worth less than today's. They suggest that discounting may be driven by uncertainty about future benefits rather than by the differential valuation of present and future deaths. ${ }^{412}$ Perhaps a fabulous new technology will cure our environmental problems or even cure the disease regulation is designed to prevent. ${ }^{413}$ Or perhaps the risk that regulation is designed to address will turn out to be lower than we have estimated it to be. Given this uncertainty, these scholars argue, we should subtract from the expected benefits of a regulation a fixed percentage for every year that passes before those benefits accrue. This is precisely what Morrall does. ${ }^{414}$

For several reasons, however, uncertainty about future benefits does not justify this kind of discounting. First, to justify discounting lives saved in the future by reference to uncertainty about future benefits is to imply that uncertainty cuts only in one direction, in the direction of fewer lives saved. But

410. See, e.g., Viscusi, supra note 398, at 437 (arguing that "lives saved in the future should be discounted to take into account the lower value such lives have when compared with lives saved currently").

411. This has also been obvious to many others. See, e.g., House SUBCOMM. ON OVERSIOHT \& INVESTIGATIONS, 99TH CONG., EPA'S ASBESTOS REGULATIONS: REPORT ON A CASE STUDY ON OMB INTERFERENCE IN AGENCY RULEMAKING 78-82 (Comm. Print 1985); STOKEY \& ZECKHAUSER, sitpra note 407, at 173-76; Michael S. Baram, Cost-Benefit Analysis: An Inadequate Basis for Health, Safety, and Environmental Regulatory Decisionmaking, 8 ECOLOGY L.Q. 473, 487 (1980); Thomas O. McGarity, Regulatory Analysis and Regulatory Reform, 65 TEx. L. REv. 1243, 1295-96 (1987); William H. Rodgers, Jr., Benefits, Costs, and Risks: Oversight of Health and Environmental Decisionmaking, 4 HARV. ENVTL. L. REV. 191, 197-98 (1980).

412. See, e.g., Farber \& Hemmersbaugh, supra note 407 , at 290 n.93.

413. See, e.g., Morrall, supra note 13, at 107-08 (arguing in favor of discounting lives saved in the future by OSHA's cotton dust standard, in part on account of "a nonzero probability of finding a cure for byssinosis"). Of course, such optimism may be unfounded. For a grim recent assessment of progress in the "war on cancer," see John C. Bailar III \& Heather L. Gornik, Cancer Undefeated, 336 NEW ENG. J. MED. 1569 (1997).

414. See Morrall, supra note 1, at 28. 
as the regulatory history discussed at length in this Article reveals, agencies are often just as convinced that their estimates of lives saved may be too low as they are that they may be too high. ${ }^{415}$ Recall that in many cases the agencies were confident that the rules in question would produce human health benefits that they were unable to quantify. ${ }^{416}$ Various features of quantitative risk assessment may also lead to an underestimation rather than overestimation of risk and thus of lives saved. ${ }^{417}$ The agencies' estimates of risk are, moreover, based on contemporaneous data like population size and life expectancy, ${ }^{118}$ figures that tend to increase over time, thereby increasing both the number of lives at risk and the number saved through regulation. Thus it appears that uncertainty justifies appreciating estimates of future benefits as much as it justifies discounting them.

Second, scientific uncertainty is already taken into account in decisions about risk regulation, not through discounting but through the methodology of quantitative risk assessment. In this context, the approach historically has been to incorporate a series of conservative assumptions into risk assessments that may tend to overestimate rather than underestimate risk, based on a policy judgment that false positives in this context are better than false negatives (although, as I have just noted, ${ }^{419}$ several features of quantitative risk assessment may also underestimate risk). ${ }^{420}$ It makes no sense effectively to undo this policy judgment by applying a discount rate to future lives saved on account of uncertainty. If the policy judgment is deemed wrong, better to undo that judgment directly and forthrightly by giving up the default assumptions considered too conservative, rather than indirectly and obliquely by applying a discount rate to scientific estimates of lives saved. ${ }^{421}$

Finally, if discounting for uncertainty is appropriate, the kind of discounting I have been discussing is an exceedingly odd way of accomplishing it. It suggests, bizarrely, that scientific uncertainty can be measured in fixed percentages and yearly packages, as if uncertainty increases, lockstep, by a specific rate every year. This might be true if, for every year that passes, there is a chance that the people who would have been saved by a regulation will die from causes unrelated to the regulated substance or

415. See, e.g., supra note 109.

416. See supra notes 108, 136, 151, 165, 272, 331, 354, 382 and accompanying text (discussing the unquantified health benefits of rules pertaining to benzene, asbestos, acrylonitrile. EDB. coke ovens, and ethylene oxide).

417. See, e.g., Proposed Guidelines for Carcinogen Risk Assessment. 61 Fed. Reg. 17.960. 17.967 (Environmental Protection Agency 1996) (proposed Apr. 23, 1996) (discussing the ways in which the default assumptions used in quantitative risk assessments may underestimale risk).

418. See, e.g., Environmental Standards for Uranium and Thorium Mill Tallings at Licensed Commercial Processing Sites, 48 Fed. Reg. 45.926, 45.928-29 (1983) (10 be codified al 40 C.F.R. pt. 192).

419. See supra note 417 and accompanying text.

420. See generally Proposed Guidelines for Carcinogen Risk Assessment. 61 Fed. Reg. 17.960. For a concise critique of current risk assessment methodologies, soe BREYER, supra note 2, at 42-50.

421. Cf. DEREK PARFt, REASONS AND PERSONS 482 (1984) (arguing that we should discount. not for time, but based on the probability that predictions will be false). 
activity; thus the probability of obtaining the expected life-saving benefits of regulation would decrease with every passing year. ${ }^{422}$ But this misconceives the nature of quantitative risk assessment. Quantitative risk assessment attempts to predict the number of lives that will be saved by a regulation, excluding other causes of death. In other words, the estimates of lives saved based on quantitative risk assessment already have taken account of the possibility that people will die of other causes before they can be saved by regulation. ${ }^{423}$

Thus uncertainty about future benefits does not provide a justification for discounting, let alone a value-free one. Aside from invoking uncertainty, another way scholars try to avoid the conclusion that discounting involves a choice about values is to observe that it is not the discounter's values that are involved. The idea here is that the discounter, in discounting, is simply reflecting the way people really think about lives saved in the future. ${ }^{424}$ The government, these scholars argue, should respect these preferences in its decisions.

There are a number of problems with this justification for discounting. First of all, it is not clear that this claim about people's preferences is factually accurate. Although some have advocated discounting on the ground that it just "seems plausible that most people would place a lower value on preventing risks that materialize in the future, ${ }^{, 425}$ the empirical evidence of people's actual preferences does not support this intuition. In fact, empirical research on intertemporal choice has found that people prefer to suffer a negative consequence sooner rather than later. In one study, for example, subjects were asked to identify "the most you would pay now" to avoid a nonlethal electric shock in five different time periods: immediately, and following delays of three hours, one day, three days, one year, and ten years. ${ }^{426}$ Subjects proved "willing to pay substantially more to avoid a shock to be received in one or ten years than one in the immediate future." ${ }^{.427}$ Likewise, subjects asked to identify the least amount of money they would demand for cleaning 100 hamster cages within the following week and one year from that time revealed

422. Cf. Farber \& Hemmersbaugh, supra note 407, at 281 n.56 ("Discounting may have evolutionary advantages given the risk that death may intervene before the decisionmaker receives future benefits.").

423. See, e.g., Occupational Exposure to Asbestos, Tremolite, Anthophyllite, and Actinolite, 51 Fed. Reg. 22,612, 22,644 (1986) (to be codified at 29 C.F.R. pts. 1910, 1926) ("In the longer exposure categories, where exposures will affect older workers, some adjustments have been made for competing risks which are likely to affect the death rate from lung cancer."); Exposure to Coke Oven Emissions, 41 Fed. Reg. 46,742, 46,750 (1976) (to be codified at 29 C.F.R. pt. 1910) ("[I]f one accounts for deaths from competing causes over the next 45 years, the estimate of excess mortality would decline to $211 . ")$.

424. See, e.g., MENDELOFF, supra note 91, at 48; PARFIT, supra note 421, at 480; see also Farber \& Hemmersbaugh, supra note 407 , at 286 (noting that concerns about paternalism justify putting the burden of proof on those who oppose discounting).

425. MENDELOFF, supra note 91 , at 49.

426. Richard H. Thaler \& George Loewenstein, Intertemporal Choice, in THE WINNER'S CURSE: PARADOXES AND ANOMALIES OF ECONOMIC LIFE 92, 104 (Richard H. Thaler ed., 1992).

427. Id. 
that they would demand more for postponing the unpleasant task. ${ }^{428}$ Such studies cast doubt on the common assumption among discounters that immediate unpleasantness is worse than postponed unpleasantness. ${ }^{429}$

Even when the postponed harm is death, rather than nonlethal harm, the empirical evidence on people's temporal preferences is decidedly mixed. One attempt to measure the discount rate reflected in workers' willingness to accept wage premiums in return for accepting a risk of long-latency disease found an implicit discount rate of approximately two percent. ${ }^{430}$ An attempt to measure the relative worth of present and future deaths more directly, through surveys rather than wage premiums, revealed a lower discount rate for a longer time horizon. Specifically, respondents in this study indicated that they would, on average, discount future lives saved at approximately eight percent per year if the lives would be saved within twenty-five years, but would discount lives saved at only about three percent per year if the lives would be saved within 100 years. $^{431}$ This suggests that the respondents, on average, valued lives saved in the distant future more highly than they valued lives saved in the near future. Individual responses in this study varied widely: Some respondents had infinite discount rates (meaning they attached no value to future lives saved) while others had negative discount rates (meaning they attached more value to future lives saved). ${ }^{432}$

One must also somehow account for the many studies showing a divergence between lay and expert views of risk. Lay people tend to perceive greater hazards from what have been called "dread" risks: risks that are characterized by, among other things, long latency periods and effects on future generations. ${ }^{433}$ These findings complicate the claim that people value lives saved today more than lives saved tomorrow as they suggest that people fear activities and substances that produce remote health effects more than they fear activities and substances that produce immediate effects. The findings also unsettle efforts to use human behavior in one context-such as the decision of many people to smoke cigarettes despite general knowledge that they are

428. See id. at 105 .

429. Cf. Richard A. Posner, Are We One Self or Multuple Selves?: Implicauons for Law and Public Policy, 3 LEGAL THEORY 23, 31 (1997) ("In thinking about the future, we discount pleasures more heavily than pains.").

430. See Michael J. Moore \& W. Kip Viscusi, Discounting Environmental Health Risks: New Evidence and Policy Implications, 18 J. ENVTL. ECON. \& MGMT. at S-5I. S-59 (1990). This contrasts with discount rates found in some of Viscusi's other work. See, e.g., VISCUSI, supra note 2, at 55. 145 (finding the discount rate for future health "in the vicinity of" $11 \%$, which is comparable to the financial rate of return on private projects); Mark K. Dreyfus \& W. Kip Viscusi. Rases of Time Preference and Consumer Valuations of Automobile Safety and Fuel Efficiency, 38 J.L. \& EcoN. 79, 98-99 (1995) (finding an implicit discount rate of $11 \%$ to $17 \%$ in private consumption decisions with respect to automobile safety).

431. See Maureen L. Cropper et al., Discounting Human Lives, 1991 AM. J. AGRIC ECON. 1410. 1413.

432. The empirical studies of discount rates for life-saving measures are discussed in Farter \& Hemmersbaugh, supra note 407 , at 283-84.

433. A classic work is Paul Slovic et al., Facis and Fears: Undersianding Perceived Risk, in Societal RiSK ASSESSMENT: How SAFE IS SAFE ENOUGH? 181 (Richard C. Schwing \& Walter A. Albers, Jr. eds., 1980). 
dangerous-to show that people, generally, prefer consumption today over health tomorrow. ${ }^{434}$ Just as people's perception of risk appears to be highly dependent on context, and on the qualitative aspects of a risky situation, their relative preferences regarding immediate and latent risks may also depend on context.

Given the conflicting evidence on preferences, it is difficult, as a factual matter, to defend the claim that discounting in general necessarily reflects people's preferences. Certainly a simple appeal to intuitions about temporal preferences cannot suffice, given the empirical evidence that is in such tension with those intuitions. In addition, it appears impossible to defend a particular discount rate-such as ten percent-as reflective of actual preferences in all regulatory contexts, across all analytical horizons. The data on people's preferences do not reflect such consistency.

Even if the empirical data were not so chaotic, a decision to discount future lives based on people's private preferences would still involve a contestable choice about values. A vast portion of our regulatory state interferes with private preferences, and a correspondingly vast literature has sprung up to defend it. ${ }^{435}$ Saying that a particular decision would reflect private preferences only begins the debate over regulatory policy. Many scholars have observed that private preferences, revealed in the market, may not reflect public preferences, revealed in decisions about government. ${ }^{436}$ And even those who are reluctant to interfere with private preferences often agree that such interference is permissible when private behavior hurts other people without compensation (or, if you prefer, creates externalities) and when market choices systematically reflect incomplete information or cognitive distortions. ${ }^{437}$ On this view, a preference for this generation's consumption over the next generation's health-a kind of externality - need not stand in the way of regulation interfering with that preference. Likewise, private preferences for risky jobs, risky products, and risky lifestyles need not inevitably impede regulation insofar as these preferences reflect incomplete information or confused thinking about risks. ${ }^{438}$ In other words, even if one finds a need for a kind of market failure or cognitive limitation to justify

434. See, e.g., MENDELOFF, supra note 91, at 49. As Mendeloff writes:

It seems plausible that most people would place a lower value on preventing risks that materialize in the future. ... [E]vidence indicates that many people, especially blue-collar workers, have high discount rates. ... . [This] can be seen in the refusal to give up behaviors Id. that are hazardous in the long run but pleasurable or difficult to give up, such as smoking.

435. For a thorough discussion of the justifications for government interference with private preferences, see Cass R. Sunstein, Legal Interference with Private Preferences, 53 U. CHI. L. REv. 1129 (1986).

436. See, e.g., Mark Sagoff, On Markets for Risk, 41 MD. L. REv. 755 (1982).

437. For a brief catalog of the reasons why government might interfere with private preferences, sec, for example, Draft Report to Congress on the Costs and Benefits of Federal Regulations, 62 Fed. Reg. 39,352, 39,355 (Office of Management \& Budget 1997).

438. See, e.g., Sunstein, supra note 435 , at $1166-69$. 
government interference with private preferences-itself a contestable proposition-one could, with little trouble, fit the differential valuation of present and future lives saved in that category.

Thus neither appeals to uncertainty nor to private preferences can squeeze the normative content out of decisions to discount lives saved. What else can be said in favor of discounting? Are the arguments for discounting that are based forthrightly on arguments about values so compelling that reasonable people may not disagree with them?

Sometimes people say that discounting is required in order to avoid ridiculous or even perverse results. This is Morrall's claim. Recall that, in calling his judgment on discounting "impeccable," Morrall explained that discounting prevented an outcome whereby one would be forced to prefer a regulation saving 100 lives a decade from now to one saving ninety-nine lives today. ${ }^{439}$ Without discounting, Morrall explained, one would be forced to conclude that "all rules yielding continuous benefits are worth any amount of immediate costs." 440 To put it slightly differently, "failure to discount would leave all generations at a subsistence level of existence, because benefits would be postponed perpetually for the future." +41

As usual, however, absurdity can be found at both extremes. Indeed, one could as easily argue against discounting on the ground that it yields obviously wrong results. As Derek Parfit has observed: "At a discount rate of five percent, one death next year counts for more than a billion deaths in 500 years. On this view, catastrophes in the further future can now be regarded as morally trivial."442 A decision, reached through discounting, to favor one life now over one billion lives in the distant future seems just as obviously wrong as the indefinite postponement of all benefits.

Moreover, the reason that postponing all benefits to a distant future seems obviously wrong - and thus lends itself to an argument from absurdity - is that, as a matter of fairness, it seems inappropriate to require excessive sacrifice on the part of one generation for another, even if, as a matter of efficiency, this is the correct result. But if the concern is about equity, then one could, following Parfit ${ }^{433}$ and John Rawls, ${ }^{\text {t4 }}$ match the principle of intergenerational efficiency, which generates the possibility of excessive sacrifice, with a principle of intergenerational equity, which strives to ensure

439. See Morrall, supra note 1 , at 28; see also supra text accompanying notes $35-37$

440. Morrall, supra note 1 , at 28.

441. Farber \& Hemmersbaugh, supra note 407, at 291 n.96 (cling DAVID IV. PEARCE \& R. KERRY TURNER, ECONOMICS OF NATURAL RESOURCES AND THE ENVIRONMENT 223-24 (1990)): see also Nichols. supra note 409 , at 176 ("Carried to its logical conclusion, the no-discounting position argues for investung all available funds for life saving in the indefinite future. rather than spending them immediately on programs that yield benefits only after a long delay.").

442. PARFIT, supra note 421 , at 357.

443. See id. at 484-85.

444. See JOHN RAWLS, A THEORY OF JUSTICE 284-93 (1971). 
a fair distribution of benefits between different generations. This would allow the present generation to avoid excessive sacrifice, even without discounting. ${ }^{445}$

Perhaps most important, the argument from absurdity depends on the idea that, without discounting of the kind I have been discussing, we would be forced-always-to prefer saving more lives in the future over saving fewer lives today if both life-saving results could be achieved at the same cost. But this just assumes that the relevant decisionmaker has the same slavish devotion to numbers as many of the people advocating discounting do. One could decide that saving fewer lives today is better than saving slightly more lives tomorrow without, at the same time, embracing the technique of applying a fixed yearly discount rate to future lives saved. The argument from absurdity depends, ultimately, on a play on words: Because we will undoubtedly sometimes prefer today's lives over tomorrow's-thus "discounting" the importance of tomorrow's lives relative to today's-we must embrace "discounting" in the sense it is understood by economists, that is, the reduction of future benefits by a fixed yearly percentage.

The predictable response to this line of argument is to say that if we ever prefer to save fewer lives today over saving more lives tomorrow at the same cost, then our decision will reflect an implicit discount rate of a certain amount. That is, we will be discounting in the way I have been discussing -reducing future benefits by a fixed yearly percentage-even if we do not acknowledge it. ${ }^{446}$ The same argument has been raised, repeatedly, in the context of valuing human life: Even if we resist assigning an explicit dollar value to saving a human life, our regulatory decisions will reflect an implicit valuation through our willingness to expend costs on saving life. ${ }^{447}$ The large and growing literature on incommensurability, however, is all about the difference between these explicit and implicit judgments. ${ }^{448} \mathrm{I}$ do not wish to wade into that debate here, except to observe that one cannot defend discounting by blithely assuming that these kinds of judgments are equivalent.

Some scholars defend discounting on the ground that people will be richer in the future, and thus the same benefits will be worth less to them than they

445. See PARFIT, supra note 421, at 484-85.

446. The empirical studies of private discount rates for life-saving investments, discussed supra notes 430-432 and accompanying text, reveal only implicit discount rates. That is, even the studies that elicited consumer preferences for present versus future life-saving through direct surveys calculated the discount rates implicit in respondents' answers rather than asking about discount rates directly. See, e.g., Cropper et al., supra note 431, at 1412-13 (discussing the methodology of a survey that asked about a hypothetical preference of saving 100 lives now or 700 lives in 50 years).

447. This is the line COWPS took in chiding OSHA for its refusal to attach an explicit dollar value to saving a life. See, e.g., Exposure to Coke Oven Emissions, supra note 213, at 6; Levine, supra note 211, at 27.

448. See, e.g., Elizabeth ANDERson, VAlue in Ethics and EConomics (1993); Cass R. Sunstcin, Social Norms and Social Roles, 96 COLUM. L. REV. 903 (1996). 
are to us, who are poorer. ${ }^{449}$ This claim is, again, easier to understand when applied to dollars. For dollars, one can cite the "diminishing marginal utility" of income, and ask, with Judge Posner: "[W]hy should we worry about reducing our consumption so that they can consume even more?"'so The argument is more complicated as applied to lives, even if the value of lives is measured in dollars. A discount rate as high as ten percent is premised on an expectation of high productivity growth, which will raise future income, which will increase the monetary value assigned to saving life. ${ }^{41}$ Thus, the very factors supporting a high discount rate also suggest that people will, in the future, value life-saving more than they value it today. This seems to me to undermine rather than support the case in favor of discounting, insofar as that case is premised on the idea that delaying life-saving diminishes its value.

Several scholars have argued that the way out of this puzzle is not to abandon discounting, but to increase the monetary valuation of lives saved in the future and then to discount that amount by the usual rate. ${ }^{452}$ Professor Viscusi has even suggested that, if the monetary valuation of lives saved in the future is properly adjusted, discounting "should not drastically affect the attractiveness of policies with long-term implications." ${ }^{.45}$ But this is to say that the only way to correct for greater future wealth in estimating the benefits of health regulation is to assign a dollar value to human life. The device of increasing the monetary value of human life will not help when it is lives, not dollars, that are being discounted. One could, I suppose, increase the estimates of the number of lives saved in order to take account of greater future wealth and then discount that number. It seems far more sensible and direct, however, simply to recognize that one argument offered in favor of discounting in general - the greater wealth of people in future years-actually cuts against discounting lives.

Equally important, the assumption that people in the future will enjoy greater wealth than they do today is in tension with the most basic premises of environmental law: that clean air, clean water, and clean land are kinds of wealth, and that they may be irreversibly threatened by actions we take today. As William Baumol wrote in an important early article on discounting the benefits of public projects: at 292 .

449. For reference to, and criticism of, this argument, see Farber \& Hemmersbaugh, supra note 407.

450. POSNER, supra note 408, at 489; see also William J. Baumol. On the Social Rate of Discount, 58 AM. ECON. REV. 788, 800 (1968) ("[I]n our economy if past trends and current developments are any guide, a redistribution to provide more for the future may be described as a Robin Hood acuvity stood on its head-it takes from the poor to give to the rich.").

451. See VISCUSI, supra note 2, at 145. This is assuming that the discount rate is based on some measure of the rate of retum on private investment. OMB's discount rate (currently seven percent) is based on such a measure. See Economic Analysis of Federal Regulations Under Executive Order 12.866 (Repor of an Interagency Group Chaired by a Member of the Council of Economic Advisers. Jan. 11. 1996).

452. See, e.g., VISCUSI, supra note 2, at 145; Farber \& Hemmersbaugh, supra nole 407, at 292 n. 101.

453. VISCUSI, supra note 2, at 145. 
There are important externalities and investments of the public goods variety which cry for special attention. Irreversibilities constitute a prime example. If we poison our soil so that never again will it be the same, if we destroy the Grand Canyon and turn it into a hydroelectric plant, we give up assets which like Goldsmith's bold peasantry, " . . . their country's pride, when once destroy'd can never be supplied." All the wealth and resources of future generations will not suffice to restore them. ${ }^{454}$

On this view, not only does the possibility of widespread irreversible damage weaken the assumption of ever-increasing wealth, it also supplies an argument against discounting in the environmental context. ${ }^{455}$

Sometimes it is said that, as long as future costs are discounted to present value, future benefits, including future lives saved, must be discounted too, in order to put costs and benefits on common terms. Indeed, in invalidating EPA's ban on asbestos, the Fifth Circuit held that EPA was required to discount benefits for this very reason:

Although various commentators dispute whether it is ever appropriate to discount benefits when they are measured in human lives, we note that it would skew the results to discount only costs without according similar treatment to the benefits side of the equation. Adopting the

454. Baumol, supra note 450, at 801 (quoting OLIVER GOLDSMITH, THE DESERTED VILLAGE 7

(Philadelphia, J.B. Lippincott Co. 1894) (1770)). Stokey and Zeckhauser make a similar observation:

It is arguable that ordinary discount rates are not appropriate for discounting flows that consist of intangibles such as pain and suffering, or improved health, or especially changes in the risk of death. Such goods are not exchanged in the market; forward and backward flows through time will not be in accord with market interest rates.

STOKEY \& ZECKHAUSER, supra note 407 , at $175-76$.

455. Surprisingly, some scholars have used the prospect of irreversible environmental damage as an argument in favor of discounting:

If preferences adapt to what is currently available (a "sour grapes" approach to amenities), then it is likely that future scarcity imposed by current consumption will not necessarily adversely affect the enjoyment of future generations. Assume, for instance, that future generations value wilderness areas less highly than the current generation does. If that change were to materialize, future generations would look askance at current decisions to forgo technological advances in order to preserve natural settings for posterity.

Gillette \& Hopkins, supra note 2, at 403. Gillette and Hopkins' reasoning is reminiscent of the following passage from an article in Science, quoted by Laurence Tribe in his famous essay on environmental law: The demand for rare environments is ... learned .... [C]onscious public choice can manipulate this leaming so that the environments which people learn to use and want reflect environments that are likely to be available at low cost. ... Much more can be done with plastic trees and the like to give most people the feeling that they are experiencing nature.

Martin H. Krieger, What's Wrong with Plastic Trees?, 179 SCIENCE 446, 451, 453 (1973), quoted in Laurence H. Tribe, Ways Not To Think About Plastic Trees: New Foundations for Environmental Law, 83 YALE L.J. 1315, 1316 (1974). This kind of reasoning would justify any amount of environmental degradation, and moreover human loss and subjugation, so long as people's preferences eventually adapted to the degradation, loss, and subjugation. This is, to say the least, an unusual use of the phenomenon of adaptive preferences. Far from being an excuse not to regulate, adaptive preferences are usually cited in defense of regulation. See, e.g., JON ELSTER, SOUR GRAPES: STUDIES IN THE SUBVERSION OF RATIONALITY 109-40 (1983); Cass R. Sunstein, Endogenous Preferences, Environmental Law, 22 J. LEGAL STUD. 217. 236-37 (1993); Sunstein, supra note 435, at 1146-50. 
position of the commentators who advocate not discounting benefits would force the EPA similarly not to calculate costs in present discounted real terms, making comparisons difficult. Furthermore, in evaluating situations in which different options incur costs at varying time intervals, the EPA would not be able to take into account that soon-to-be-incurred costs are more harmful than postponable costs. Because the EPA must discount costs to perform its evaluations properly, the EPA also should discount benefits to preserve an applesto-apples comparison ....456

One worries about "preserv[ing] an apples-to-apples comparison," however, only if one is dealing only with apples. In the asbestos case, the costs were dollars and the benefits were lives. These costs and benefits are the same only if dollars and lives are the same. Again, therefore, it turns out that the implicit premise of an argument in favor of discounting is that lives can be measured in dollars. Far from being a "value-free and good workable rule," "ss as Morrall has claimed, the decision to treat future costs and benefits the same-to discount them both and to discount them at the same rate-silently resolves one of the central moral questions of the modern regulatory state.

The problems do not end there. The reigning theory about the appropriate way to value human lives-which holds that lives should be valued by asking how much money people would be willing to spend to avoid small reductions in risk or how much they would demand to accept them ${ }^{488}$-depends on a premise fundamentally at odds with the premise of discounting lives. Discounting is used, as I have said, to calculate the present value of future benefits. To decide whether discounting is necessary, one must have some notion of what the relevant benefit is and when it occurs. The benefit of a regulation reducing the risk of a long-latency disease could be regarded either as an immediate reduction in risk of future death or as the future avoidance of death $^{\text {itself. }}{ }^{459}$ To justify discounting in this context, one must say that the benefit of such regulation is the prevention of death (which occurs in the future), not the reduction of risk (which occurs as soon as the regulation is implemented). But this is not the way benefits are described in the context of valuing human lives according to the willingness to pay. In that context, sophisticated observers realize that it is crazy to talk about a rational person's willingness to accept money in exchange for certain death. Most people would not accept such an exchange. Instead, the bargain being valued is described as

456. Corrosion Proof Fittings v. EPA. 947 F.2d 1201, 1218 (5th Cir. 1991).

457. Morrall, supra note 13 , at 107.

458. This approach is often defended, despite its limitations, as better than other avalable valuation methods, such as the "human capital" approach. See, e.g. Gilletle \& Hopkıns, supra note 2, at 382-99. For the seminal work on willingness-to-pay approaches to valuing life, see Thomas Schelling. The Lefe You Save May Be Your Own, in Problems IN PUblic EXPENdTURe ANalysis 127 (Samuel B Chase. Jr ed.. 1968), reprinted in THOMAS SCHELLING, CHOICE AND CONSEQLENCE 113 (1984)

459. See, e.g., Gillette \& Hopkins, supra note 2, at 401. 
the acceptance of money in return for acceptance of slightly increased risk of death. ${ }^{460}$ In other words, the benefit to be measured is the reduction in risk, not the avoidance of death.

Thus, the very move that makes it possible even to talk about valuing life in terms of dollars also makes it clear that the benefit being measured is a reduction in risk, not an avoidance of death. If a reduction in risk is the relevant benefit for purposes of valuation, it must also be the relevant benefit for purposes of discounting. This benefit accrues as soon as exposure to the risky substance or activity is reduced. ${ }^{461}$ In many cases, this will occur roughly contemporaneously with the expenditure of costs, rendering discounting unnecessary. This line of reasoning would suggest that discounting, if it is to be done at all, should be done only for the short interval between expenditure of costs and reduction in risk, not for the interval between the reduction in risk and the saving of lives.

Of course, one might still say that there is a difference between the reduction in a risk that will materialize in harm, if at all, immediately or in the near future, and the reduction in a risk that will materialize in harm, if at all, in the distant future. One might value the reduction in the former risk more than the reduction in the latter, and on this view discounting would still be appropriate even if the relevant injury is regarded as the risk, rather than the development of disease or death itself. But the existing empirical evidence on people's preferences as between risks materializing in harm over different temporal periods is, as I have explained, ${ }^{462}$ inconclusive as to which kind of risk people actually prefer. Absent new and different empirical evidence on people's preferences, the preference-based argument for discounting remains tethered to a normative assumption about what people's preferences should be rather than what they are.

All of this suggests that the practice of discounting future lives saved embodies normative choices at the core of modern risk regulation. ${ }^{463}$ This

460. See, e.g., MENDEloff, supra note 91, at 27; Glenn C. Blomquist \& Sam Peltzman, Passive Restraints: An Economist's View, in THE SCIENTIFIC BASIS OF HEALTH AND SAFETY REGULATION, supra note 13, at 37, 48; Farber \& Hemmersbaugh, supra note 407, at 276.

461. See House SUbCOMM. ON OVERSIGHT \& INVESTIGATIONS, supra note 411 , at 80.

462. See supra notes $425-434$ and accompanying text.

463. In this discussion, I have ignored the question that has preoccupied most scholars of this subject, which is the choice of a particular discount rate. 1 have focused instead on the normative choices implicit in the decision whether to discount lives at all. I should note, however, that there appears to be a growing consensus, even among advocates of discounting, that $10 \%$ is too high a discount rate for public endeavors like the regulations on Morrall's list. See, e.g., Gillette \& Hopkins, supra note 2, at 407 ("[M]ost would agree that $10 \%$ is too high a rate."). Indeed, OMB itself has reduced the discount rate presumptively applicable to cost-benefit analyses of regulatory actions from $10 \%$ to $7 \%$. See Benefit-Cost Analysis of Federal Programs; Guidelines and Discounts, 57 Fed. Reg. 53,519, 53,522-23 (1992). Others have argued for an even lower discount rate for the benefits of health and environmental regulation, on the order of $1 \%$ to $2 \%$. See, e.g., Farber \& Hemmersbaugh, supra note 407 , at 303.

There is also increasing recognition, even by Morrall himself, that the discount rate should be sensitive to context. See, e.g., Morrall, supra note 1, at 28 . Even assuming that discounting lives is appropriate, the discount rate appropriate for projects that draw resources from investment, for example, 
leads me to three conclusions. First, decisions about discounting future lives saved-including decisions about whether to discount at all, and, if so, about what discount rate and discounting period to assume-should be explicit and transparent. These choices are too important and too value-laden to be buried in work papers, in footnotes, or even in textual discussions, where the textual discussion is-as in Morrall's paper-segregated from the numerical results of the analysis.

Second, where estimates of regulatory benefits already incorporate discounting, it is sheer bootstrapping to use those same estimates to argue that the benefits of health regulation are trivial or that health regulation that addresses long-latency diseases and long-term ecological threats is, systematically, less cost-effective than safety regulation. These conclusions are already built into the estimates of benefits through the practice of discounting. The estimates are merely a numerical representation of these ideas.

Finally, the breezy attitude that has characterized so much of the case in favor of discounting - "surely people prefer postponed harm to immediate harm"; "surely benefits must be discounted if costs are"-must give way to a more serious and sustained examination of the factual and normative premises of this technique. More empirical work, for example, needs to be done to sor out the conflicting evidence on people's preferences. And scholars and policymakers should accept the possibility that people's preferences about risk will not be linear across time. ${ }^{464}$ Moreover, approaches to discounting should vary across contexts. The easy assumption that all the future benefits of all health regulations should be discounted, and discounted at the same rate, ignores the fact that health regulations are not all alike. They differ, among other things, in their relative effects on present and future generations; in the relative magnitude of their unquantified, and perhaps immediately realized, benefits; and in their expected effects on the environment.

Thus, more case-by-case attention needs to be given to the question of whether the future benefits of health and environmental regulation should be

is different from the one appropriate for projects that draw resources from consumption Morrall humself recognizes as much but says that "the analytical demands of tallonng a precise discount rate for each rule were impossibly large, and for comparative purposes the benefits of the grenter precision would have been small." Id. This is perplexing. The choice between a $10 \%$ discount rate and. say, a $1 \%$ rate makes an extraordinary difference in the attractiveness of programs producing benefits remote in ume. (At a discount rate of $10 \%$, a rule predicted to save 10 lives in 25 years would be treated as saving 0.92 lives: at a discount rate of $1 \%$, the same rule would be treated as saving 7.97 lives.) And it is not immediately apparent why the analytical demands of identifying the appropnate discount rate for each rule are any more prohibitive than the analytical demands of applying cost-benefit or cost-effectiveness analysis to cach rule (though proponents of these methods, such as Morrall, would insist that their analytucal demands are manageable). At the very least, then, according to a growing consensus even among proponents of discounting, Morrall's list reflects a discount rate that is at once 100 high and 100 uniform.

464. It is quite possible, to take just one example, that many people care more about nsks to their children than they do about risks to themselves but that their concern about future harm then dissipates for succeeding generations. For a discussion of intergenerational discountung concems. see, for example. Farber \& Hemmersbaugh, supra note 407 , at $281-87$. 
discounted at all, and, if so, at what rate. More case-by-case work is also needed to identify the appropriate discounting period. For example, in deciding how long a period to assume in discounting the benefits of cancer-preventing rules, one must determine the latency period for the kinds of cancers, and kinds of exposures, prevented by such rules. Latency periods vary not only according to the type of cancer involved ${ }^{465}$ but also according to the timing and intensity of exposure. ${ }^{466}$ Estimates of latency periods have also varied according to the assumed terminal point of the latency period, that is, whether onset of symptoms, diagnosis, or death is assumed to mark the end of the latency period. ${ }^{467}$ Moreover, some have argued that the status of a particular substance as an early- or late-stage carcinogen goes a longer way toward elucidating the temporal distribution of cancer risk than does the concept of latency. ${ }^{468}$ In sum, the identification of an appropriate period over which to discount the benefits of cancer-preventing regulation is a matter filled with variation and uncertainty. Indeed, this may be another argument against discounting altogether. ${ }^{469}$

\section{Quantitative Risk Assessment}

I have explained that the disparities between the agencies' and Morrall's estimates of costs per life saved are attributable not only to discounting but also to Morrall's adjustments to the agencies' estimates of risk. ${ }^{470}$ Save for the case of OSHA's ethylene oxide rule, ${ }^{471}$ however, Morrall does not elaborate upon his reasons for these adjustments. As to that rule, recall that Morrall explained that he chose to use EPA's estimates of risk rather than

465. See B.T. Westerfield, Asbestos-Related Lung Disease, 85 S. MED. J. 616, 618-19 (1992) (reporting different latency periods for asbestos-related lung cancer and mesothelioma).

466. See Harvey Checkoway et al, Latency Analysis in Occupational Epidemiology, 45 ARCilves ENVTL. HEALTH 95, 99 (1990).

467. See Richard B. Hayes \& Paolo Vineis, Time Dependency in Human Cancer, 75 TUMORI 189, 190 (1989).

468. See id. at 194.

469. Confusion over the appropriate discounting interval is evident in Morrall's calculations. By comparing the agencies' estimates of total compliance costs and lives saved with Morrall's cstimates of costs per life saved (which incorporate the compliance costs estimated by the agencies), one can derive Morrall's estimate, after discounting, of the number of lives saved. By plugging all these numbers into the formula for calculating present value, one can then derive the number of years Morrall must have assumed would pass before lives were saved. The general formula for calculating the present value of a benefit of $X$ to be received $N$ years from now when the discount rate is $r$ is: $X /(1+r)^{N}$. See BAUMOL \& BLINDER, supra note 407 , at $386-87$. If one performs these calculations with respect to three different arsenic rules (OSHA's 1978 arsenic rule and EPA's 1986 rules on glass plants and copper smelters), one finds that Morrall assumed three different latency periods for these rules: 15 years for the glass plants rule, 30 ycars for the copper smelters rule, and 37 years for OSHA's rule. Given that all three rules addressed the same carcinogenic substance operating through the same route of exposure, the variation in discounting intervals is perplexing. Perhaps it can be explained by differences in exposures, but this is unknown.

470. See supra Subsection II.B.2.

471. See Occupational Exposure to Ethylene Oxide, 49 Fed. Reg. 25,734 (1984) (to be codified at 29 C.F.R. pt. 1910). 
OSHA's because (he thought) EPA's estimates were based on epidemiological rather than animal studies. ${ }^{42}$ For the adjustments made with respect to the other rules, however, we do not have an explanation other than that Morrall chose what he regarded as the "most reliable" estimates of risk."

Several general remarks about the normative choices embodied in quantitative risk assessment will therefore suffice. Quantitative risk assessment produces "a numeric estimate of the possibility of cancer in a given population over a lifetime from exposure to a chemical substance." ${ }^{\text {its }}$ It does this through reliance on studies showing elevated risks of cancer in either humans or animals. Almost always, however, the epidemiological and experimental data are based on exposures that are higher than those of regulatory concern. ${ }^{475}$ Thus, some method of extrapolating from high-dose to low-dose exposures is necessary in order to produce numerical estimates of risks at the relevant exposures. The extrapolation model used can have an enormous impact on the numerical assessment of risk. When relying on animal studies, risk assessors must also figure out how to translate risks found in animals to risks in humans. This decision, too, can have a large effect on conclusions about risk. Each of these decisions is typically made in the absence of scientific proof about what decision is appropriate. Such decisions have thus come to be known as "default assumptions," operative in the absence of evidence indicating that they are invalid in a particular case. ${ }^{476}$

The use of default assumptions, and the assumptions themselves, generally spring from two normative choices that lie at the heart of risk regulation. First, the whole point of risk regulation is to prevent harm before it occurs. This is part of the reason why reliance on animal studies is a nearly inevitable part of quantitative risk assessment; to require adequate epidemiological studies would be to require people to die or fall ill before regulation could take place. Second, a basic ethic of risk regulation is that it is worse to be proven to have been overly optimistic about a risk than to be proven to have been unduly pessimistic; or, in other words, false positives are worse than false negatives. ${ }^{477}$ Thus, many of the default assumptions underlying quantitative risk assessment tend to be public-health conservative, insofar as it is more likely that they overstate risk than that they understate it.

472. See supra text accompanying note $357-368$.

473. Morrall, supra note 1 , at 28.

474. Mark Eliot Shere, The Myth of Meaningful Environmental Risk Assessment. 19 HarV. EvVTL. L. REV. 409, 412 (1995).

475. See, e.g., Latin, supra note 109 , at 98.

476. For a concise description of the major default assumptions used in quantitatuve nst assessment. see JOSEPH V. RODRICKS, CALCULATED RISKS $188-89$ (1992). For a discussion of Justufications for departures from default assumptions, see Proposed Guidelines for Careinogen Risk Assessment, 61 Fed. Reg. 17,960 (Environmental Protection Agency 1996) (proposed Apr. 23. 1996).

477. For discussion of limiting false positives and false negatives in the context of environmental law. see Talbot Page, A Generic View of Toxic Chemicals and Similar Risks. 7 EcoLocy L.Q. 207. 230-36 (1978). 
For these reasons, risk assessments have historically tended to emphasize the upper bound of the large range of estimates typically produced through quantitative risk assessment; ${ }^{478}$ the notion is that the actual risk is unlikely to be above the highest plausible estimate derived in the risk assessment. By relying on one risk estimate in preference to another on the ground that it allegedly better reflects "prevailing scientific views," ${ }^{, 79}$ Morrall implicitly rejects the conservatism built into risk assessments through, among other things, the emphasis on highest plausible risks. But in a matter riddled with uncertainty, deciding whether to favor low, medium, or high estimates of risk is not a purely scientific choice. ${ }^{480}$

Moreover, even if one accepted the intuitive appeal of stressing the "best" (and lower) estimate of risk, deciding which risk estimate is "best" can itself be as much a matter of political as of scientific judgment. In estimating the costs per life saved of OSHA's formaldehyde rule, ${ }^{481}$ for example, Morrall appears to have relied on figures calculated by OMB economists untrained in the scientific disciplines that contribute to our understanding of risk, such as epidemiology, biochemistry, and toxicology. ${ }^{482}$ And in estimating the costs of OSHA's ethylene oxide rule, ${ }^{483}$ Morrall inexplicably chose to rely on the results of epidemiological studies that nearly everyone involved in the rulemaking proceeding agreed were flawed. ${ }^{484}$ This picking and choosing among the results of various risk assessments is as easily explained by a desire to undermine the case for regulation as it is by a desire to get at scientific "truth." Truth in this area is slippery; one may, using the same epidemiological or experimental database, reach dramatically different estimates of risk simply by applying different statistical models for extrapolating from high to low doses and from animals to humans. Anyone with training in statistics might therefore convince himself that he is as qualified to perform quantitative risk assessment as someone with training in epidemiology, biochemistry, toxicology, or industrial hygiene. One should be wary of accepting an economist's adjustments to agencies' risk assessments, especially when those adjustments are largely unexplained.

I cannot leave the subject of risk assessment without touching on Morrall's estimates of risks from safety (as opposed to health) hazards. As I noted earlier, ${ }^{485}$ Morrall explains that the safety risks reported in his table are less

478. See Adam M. Finkel, A Return to Alchemy, ENVTL. F., Sept.-Oct. 1996, at 15, 16-17.

479. Morrall, supra note 1 , at 28-29.

480. For elaboration of this idea, see Finkel, supra note 478, at 16-17.

481. See Occupational Exposure to Formaldehyde, 50 Fed. Reg. 50,412 (1985) (to be codified at 29 C.F.R. pt. 1910) (proposed Dec. 10, 1985).

482. See supra text accompanying notes 288-289.

483. See Occupational Exposure to Ethylene Oxide, 49 Fed. Reg. 25,734 (1984) (to be codified at 29 C.F.R. pt. 1910),

484. See supra text accompanying notes 357-364.

485. See supra text accompanying note 46 . 
likely to be overstated than the health risks on account of "the greater availability of hard data" on safety risks. ${ }^{486}$ It is interesting to consider what Morrall considers "hard data." Take, for example, the Consumer Product Safety Commission (CPSC) rule on unvented space heaters, which occupies the enviable position of second from the top of Morrall's original list ${ }^{487}$ and is at the very top of some later versions. ${ }^{48}$ This rule required an oxygen detection system for unvented space heaters, which would shut off the heater when oxygen levels were so depleted that the heater would pose a risk of carbon monoxide poisoning. ${ }^{489}$ The CPSC estimated that the addition of an oxygen detection system to the 120,000 heaters expected to be produced in 1980 would save fourteen lives over the life of the heaters. ${ }^{400}$ By the time nearly all unvented space heaters complied with the new standard, the rule would save sixty-three lives per year. ${ }^{491}$

The estimate of fourteen lives saved in relation to the 1980 production run was based on the following chain of data and reasoning. In 1977, the agency reported, there were 176 deaths from all domestic-fueled heaters. ${ }^{392}$ In arriving at this number, the agency estimated that there were 348 poisonings by residential fuels in $1978 .{ }^{493}$ Based on CPSC's specific information on 289 of these incidents, the agency figured that half of the poisonings in 1978 were due to space heaters. ${ }^{494}$ CPSC then had to convert the figure of 176 deaths from all space heaters to an estimate of deaths from unvented space heaters. It did this by considering the results of forty-one investigations of such deaths. Based on ratios it found in these studies, CPSC estimated that approximately $61 \%$ of the 176 deaths from space heaters were due to unvented space heaters. ${ }^{495}$ CPSC adjusted the resulting figure of 106 deaths, in an unelaborated way, to account for "regional differences" and "possible bias" in investigative files. ${ }^{496}$ This led to the figure of seventy deaths per year. There

486. Morrall, supra note 1, at 32.

487. See id. at 30 tbl.4.

488. See, e.g., Viscusi, supra note 2, at 1432-33 tbl.l.

489. See Safety Standard Requiring Oxygen Depletion Safety Shutoff Systems (ODS) for Unvented Gas-Fired Space Heaters, 45 Fed. Reg. 61,880 (1980) (to be codified at 16 C.F.R. pt. 1212).

490. See id. at 61,927 . CPSC estimated the life of a space heater to be 25 years. Because its estumates of lives saved were based on this long time interval, Morrall should have discounted lives saved due to this rule too in order to be consistent with his approach to health regulation. There is no evidence that he did this, as his table reports costs per life saved $(\$ 100,000)$ that lie at the mid-range of CPSC's undiscounted estimates. See id. at 61,926.

491. See id. at 61,928 n.8. This would not happen for approximately 64 years, the ume it would take for the nation's inventory of approximately 7.7 million space heaters to tum over at a rate of 120,000 per year. See id. at 61,927 . For his par, Morrall reports that the rule will save 63 lives per year, without noting that this would not happen for over 60 years. See Morrall. supro note 1. at 30 tbl.4.

492. See Safety Standard Requiring Oxygen Depletion Safety Shutoff Systems (ODS) for Unvented Gas-Fired Space Heaters, 45 Fed. Reg. at 61.923-24.

493. See id. at 61,923 .

494. See id. Half of 348 , however, is 174 not 176.

495. See id.

496. Id. at 61,924 . 
were 7,681,000 space heaters then in existence. ${ }^{497}$ Combining the death rate with the number of heaters led to a death rate per heater of 0.0000091 . The agency estimated that there would be approximately 120,000 space heaters manufactured in $1980 .{ }^{498}$ The death rate of 0.0000091 , multiplied by 120,000 , led to an estimate that, absent regulation, sixteen deaths would occur during the life of the space heaters manufactured in 1980. After assuming that the oxygen detection system would be $90 \%$ effective in preventing poisonings, the CPSC finally concluded that the oxygen detection system would save fourteen lives if installed in heaters made in $1980 .{ }^{499}$

Are these hard data? Where is the evidence that 1977 and 1978 were representative years as far as poisonings from space heaters were concerned? Or the evidence that the data from forty-one cases were representative? What was the empirical basis for the adjustments for regional differences, bias in investigative files, and effectiveness? Was it reasonable to assume that the number of space heaters would remain stable in the future? The conclusion seems inescapable that CPSC's estimate of lives saved was based on inferences and hunches-even guesses-in the same way that estimates of risk from carcinogenic substances are. Agency estimates of lives saved by other safety regulations on Morrall's list exhibit similar guesswork. ${ }^{500}$ All this suggests that "hard data" on risk are elusive, even when the risk is to safety rather than health.

\section{Regulatory Purposes}

In reporting regulatory cost-effectiveness as a function of human lives saved (and only quantified lives at that), Morrall's table implies that risk regulation is exclusively concerned with quantifiable human health risks. This ignores the many benefits of health and environmental regulation that are not susceptible to quantification and that range beyond human health.

A focus on quantifiable human health risks leads in practice to a fixation on cancer risks. ${ }^{501}$ Despite the many limitations of carcinogen risk

497. See id. at 61,927 .

498. See id.

499. See id.

500. See, e.g., Airplane Cabin Fire Protection, 49 Fed. Reg. 21,010, 21,012-14 (1984) (to be codified at 14 C.F.R. pt. 121) (notice of proposed rulemaking, May 17, 1984) (estimating benefits of a rule requiring smoke and fire detectors in airplane galleys and lavatories by considering the number of deaths in airplane fires from 1973 to 1983, as reduced by assumptions about the effectiveness of the newly required devices in preventing deaths).

As for Morrall's figures on the lives saved by the safety rules on his list, in some cases it is simply hard to fathom how he came up with his estimates. Compare Morrall, supra note 1, at 30 tbl.4 (estimating that the FAA's rule on seat cushion flammability will save 37 lives per year), with Flammability Requirements for Aircraft Seat Cushions, 49 Fed. Reg. 43,188, 43,191 (1984) (to be codified at 14 C.F.R. pts. 25, 29, 121) (estimating the range of annual lives saved from a low of 4.4 to a high of 22.3). 1659.

501. See, e.g., OfFICE OF POLICY ANALYSIS, supra note 67, at 98-99; Applegate, supra note 71, at 
assessment, this remains the best-developed branch of quantitative risk assessment. This is why, in justifying the rules on Morrall's list, the agencies generally quantified only risks of cancer. But these agencies frequently cited health benefits in addition to the prevention of cancer. ${ }^{502}$ These included the prevention of reproductive abnormalities and dysfunctions, neurological effects, blood disorders, and other ailments. In the case of EPA's asbestos ban, for example, the unquantified benefits included even the prevention of asbestosis, one of the signature illnesses associated with the substance. ${ }^{503}$ The agencies did not just make up these risks but relied on scientific studies showing that the risks existed. They were not, however, able to quantify them.

Focusing on human lives saved also ignores consequences beyond human health. Hazardous waste disposal, radioactive contamination, and air pollution-the harms targeted by the environmental rules on Morrall's list-all affect living things besides humans. These effects are, if anything, even harder to quantify than are human health effects. Thus, agencies frequently cite ecological benefits without quantifying them. ${ }^{\text {sot }}$

Finally, a narrow focus on human morbidity and mortality effectively dismisses the great body of evidence showing that, when citizens think about risk, they think about more than mortality and morbidity. ${ }^{\text {sos }}$ They also consider such things as whether the consequences are immediate or latent, diffuse or catastrophic, certain or uncertain. And people care about whether the consequences are equitably or inequitably imposed and whether they fall on the present generation or on future generations. To quote Mark Sagoff:

In the regulation of risk, safety is not our only goal, and it may not . even be our principal concern. We are also concerned about man's inhumanity to man. We rightly spend more to reduce comparatively small risks that outrage us than to reduce larger risks that occasion no such resentment. The acceptability of risk may depend less on its magnitude than on its meaning. ${ }^{506}$

502. See supra notes $108,136,151,165,272,331,354,382$ and accompanying lext (discussing the unquantified health benefits of rules pertaining to benzene, asbestos, acrylonitrile, EDB, coke ovens, and ethylene oxide).

503. See Asbestos; Manufacture, Importation, Processing, and Distribution in Commerce Prohibutions, 54 Fed. Reg. 29,460, 29,468 (1989) (to be codified at 40 C.F.R. pt. 763).

504. See, e.g., id. at 29,480 (mentioning the unquantified environmental benefits of the asbestos ban); Land Disposal Ban, 51 Fed. Reg. 44,714, 44,737-38 (1986) (to be codified at 40 C.F.R. pts. 260-62, 264$65,268,270-71$ ) (mentioning the unquantified environmental benefits of the land disposal ban). See generally Lisa Heinzerling, Reductionist Regulatory Reform, 8 FORDHAM ENVTL. LJ. 459 (1998) (discussing EPA's tendency to leave ecological benefits of regulation unquantified).

505. See, e.g., Paul Slovic, Perception of Risk, 236 SCIENCE 280 (1987).

506. Mark Sagoff, Forum One-The Policy. EPA J., MarJApr. 1991, at 30. 30. quoted in Rober R. Kuehn, The Environmental Justice Implications of Quantitative Risk Assessment, 1996 U. ILL L. REV. 103. 127. 
In short, the benefits of the rules on Morrall's list include what have come to be known as the "nonstatistical" or "qualitative" features of risk, such as autonomy, community, and equity. ${ }^{507}$

Some observers, in fact, have suggested that at least part of the disparities in regulatory costs shown on Morrall's list can be explained by reference to these unquantified and nonstatistical features of risk. ${ }^{508}$ They have found the disparities too great, however, to be explained wholly in these terms. ${ }^{509}$ But if one uses the estimates of costs per life saved that I have derived based on the agencies' estimates of risks and costs, then the wide disparities in regulatory costs either disappear altogether or shrink to a size that could be explained by reference to the unquantified benefits of the rules in question. ${ }^{510}$

It would not surprise me to learn that Morrall and most if not all of the regulatory reformers who have relied on his table believe that human health effects other than cancer, ecological effects, and the nonstatistical features of risk are all appropriate objects of regulatory concern. Nor would it surprise me to learn that most if not all of them believe that these effects are real costs of nonregulation and that preventing them is a real benefit of regulation. But these concessions have little significance unless one allows these benefits to have a meaningful, even decisive, impact on regulatory decisions. ${ }^{511}$

The implicit message of Morrall's list is that the greatest benefits of regulation are covered there and that any adjustments based on noncancer

507. For a sustained defense of the incorporation in risk regulation of the features of risk ranging beyond human morbidity and mortality, see Pildes \& Sunstein, supra note 53. See also Clayton P. Gillette \& James E. Krier, Risk, Courts, and Agencies, 138 U. PA. L. Rev. 1027 (1990); Donald T. Hornstein, Reclaiming Environmental Law: A Normative Critique of Comparative Risk Analysis, 92 CoLUM. L. REv. 562 (1992).

508. See, e.g., Sunstein, supra note 455 , at 251-52.

509. See, e.g., id.

510. Gillette and Hopkins urge greatest caution in making regulatory decisions turn on willingness to pay precisely in those situations where regulatory costs are closest to willingness-to-pay values:

Our critique of willingness-to-pay ... . should be understood less as an appeal to ignore these studies than as a warning to understand their limitations. Acceptance of findings from these studies should be viewed most skeptically where they produce dollar values close to the cost per life of proposed regulations, for it is in those situations that failure to consider all relevant variables will have the greatest impact on ultimate result.

Gillette \& Hopkins, supra note 2, at 399.

511. In its decision invalidating EPA's asbestos ban, the Fifth Circuit conceded the legal relevance of unquantified benefits and then effectively held that they could not play an important role in decisionmaking under the Toxic Substances Control Act (TSCA), 15 U.S.C. $\$ 2605$ (a) (1994):

While TSCA contemplates a useful place for unquantified benefits beyond the EPA's calculation, unquantified benefits never were intended as a trump card allowing the EPA to justify any cost calculus, no matter how high.

....

Unquantified benefits can, at times, permissibly tip the balance in close cases. They cannot, however, be used to effect a wholesale shift on the balance beam. Such a use makes a mockery of the requirements of TSCA that the EPA weigh the costs of its actions before it chooses the least burdensome alternative.

Corrosion Proof Fittings v. EPA, 947 F.2d 1201, 1219 (5th Cir. 1991). The court went on to state that "[b]y not using such concerns in its quantitative analysis, even where doing so was not difficult, and reserving them as additional factors to buttress the ban, the EPA improperiy transformed permissible considerations into determinative factors." Id. at 1219 n.20. 
health effects, ecological effects, and the nonstatistical features of risk would not disturb the relative rankings of the rules on the list. This is certainly the way the list has been interpreted. ${ }^{512}$ This is a tempting view since the benefit cited on the list (human lives saved from cancer) is a big one. There is no empirical basis, however, for concluding that the cancer risks cited on Morrall's list dwarf the other risks posed by these substances; the size of a risk does not determine our capacity to quantify it. There is growing evidence, for example, that many synthetic chemicals disrupt human and animal endocrine systems, causing such diverse problems as abnormal reproductive function and impaired cognitive development. ${ }^{513}$ We may eventually come to understand that such consequences are more serious and widespread than the carcinogenic effects of these chemicals, but so far researchers have been unable to quantify these emerging threats. To say nevertheless that cancer must be the biggest threat from the chemicals on Morrall's list because we can measure the risk of cancer is to give in to a kind of cognitive distortion. The ability to quantify cancer risks makes such risks vivid to us-or "available" to us-in a way that unquantified risks are not. But availability should not be confused with magnitude..$^{514}$

The assumption that the consequences we can quantify dwarf the ones we cannot also makes some previous regulatory decisions look very odd. For example, when the EPA proposed phasing down the amount of lead in gasoline, it did so because of concern about the health effects caused by lead in children's blood. ${ }^{515}$ When it came time to quantify the costs and benefits of the proposed phasedown, however, the greatest quantified benefit turned out to be not improved children's health, but improved maintenance for cars and other vehicles. ${ }^{516}$ If one looked at EPA's quantification of costs and benefits in isolation, one would have to conclude that the major benefit of the rule was its effect on cars rather than its effect on people. This would be an absurdly wrong interpretation.

In sum, fixation on quantified benefits to human health either assumes, as a normative matter, that benefits that cannot be counted do not count, or assumes, as a factual matter, that benefits that cannot be counted are not very

512. See, e.g., Cass R. Sunstein, Legislarive Foreword: Congress. Constitulional Moments, and the Cost-Benefit State, 48 STAN. L. REV. 247, 258-60 (1996) (recognizing the benefits besides human lives saved, but concluding that "in the face of these variations [in costs per life saved]. good pnority-setting is unlikely").

513. For a catalog of the scientific evidence of harms from hormone-disrupting chermicals, see THEO COLBORN ET AL., OUR STOLEN FUTURE (1996).

514. Cf. Amos Tversky \& Daniel Kahneman, Availabilin: A Heurisfic for Judging Frequency and Probability, 5 COGNITIVE PSYCHOL. 207, 208 (1973) ("A person is said to employ the availability heuristic whenever he estimates frequency or probability by the ease with which instances or associations could be brought to mind.").

515. See PERCIVAL ET AL., supra note 72, at 489-91.

516. See id. at 563 fig.4.9 (citing SCHWARTZ ET AL., supra note 199, at VIII-26 tbl.VIII-8). 
big. The first assumption involves a choice of values, about which reasonable people may disagree. The second is a hopeful superstition.

\section{Conclusion}

The numbers in Morrall's table, and in my own, embody normative choices that lie at the heart of current debates about the regulatory state. Moreover, the observations I have made with respect to the values underlying these two tables are not unique to our two tables. One cannot construct any table of this sort-reflecting costs per life saved-without making such choices. In order to determine the denominator in the relevant fraction-lives saved-one must take a stand on discounting and on appropriate methodologies for quantitative risk assessment. One must also decide whether the very project of measuring regulatory benefits solely in terms of human lives saved takes inadequate account of other regulatory benefits. In short, a value-free table of this kind does not exist.

\section{B. Danger in Numbers}

There are two standard responses to the observation that numerical representations of risks, costs, and benefits embody important choices about values. One response is to suggest that the underlying values be more forthrightly acknowledged. Where, for example, quantitative risk assessments incorporate default assumptions, which themselves incorporate political or moral choices, many observers have proposed that the implicit choices be made explicit. ${ }^{517}$ Another response-consistent, and often overlapping, with the first-is to propose the incorporation of a wider range of values in numerical estimates of the costs and benefits of regulation. ${ }^{518}$ I do not place much stock in either of these alternatives.

\section{More Words?}

The experience with Morrall's table should be convincing evidence that all the explicit qualifications in the world will not neutralize the impact of a table of impressive numbers. When he produced his table in 1986, Morrall dutifully informed his readers that he had discounted lives saved by ten percent per

517. See, e.g., Proposed Guidelines for Carcinogen Risk Assessment, 61 Fed. Reg. 17,960, 17,965 (Environmental Protection Agency 1996) (proposed Apr. 23, 1996) (stating that "these guidelines call for identification of the default assumptions used within assessments"); COMMITTEE ON RiSK ASSESSMENT OF HAZARDOUS AIR POLLUTANTS, supra note 364, at 81 (urging EPA to adopt "principles for choosing default options and for judging when and how to depart from them," and describing public policies that underlic choices among default options).

518. See, e.g., Pildes \& Sunstein, supra note 53, at 75-86 (discussing three methods of capturing lay valuations of health quantitatively). 
year. But this table has since been reproduced dozens of times without reference to, or indeed apparent knowledge of, this adjustment. The lack of awareness of this adjustment is illustrated most dramatically by the fact that several of the scholars who have cited Morrall's table for the truth of the assertion that regulatory costs are either wildly variant or wildly high, ${ }^{319}$ have also argued against application of a ten percent discount rate in the very same pieces of scholarship. ${ }^{520}$

Especially when a table can be plucked from an article in one clean page, without taking along with it any qualifications, explanations, or caveats, the danger of misinterpretation and misunderstanding is great. The excision of Morrall's table from his discussion of how he derived the numbers reflected therein has contributed to over a decade's worth of overconfident and overblown claims about the costs of the regulatory state.

There is no reason to believe that the inattention to Morrall's explanation of the numbers in his table, and others' seizing upon these numbers as if they were incontrovertible, are unique to this setting. ${ }^{521}$ In the area of quantitative risk assessment, for example, the power of numbers is deemed so great that everyone seems to agree that numerical estimates of risk should be ringed by qualifications, caveats, and expressions of uncertainty. ${ }^{522}$ The special power of numbers has been remarked upon in other contexts as well. ${ }^{523}$ The emerging literature on differences in people's perception of numerically and linguistically expressed risk is especially instructive here. One study in this area concluded that

[w] hen faced with a high chance of a gain, individuals want to lock in the "sure thing" that numeric risks provide[], and when faced with the high chance of a loss, they want the linguistic risk which provides the possibility [that] the actual chance of loss will come from the lower tail of the distribution. ${ }^{524}$

All in all, there can be little doubt that numerical precision is often mistaken for accuracy and certainty. My point is that there is no evidence that this problem will be solved by surrounding the numbers with words.

519. See, e.g., Gillette \& Hopkins, supra note 2, at $405-06$ (c)tung 1987-1988 OMB RњPORT. supra note 3, at Xx-xxii, which cites Morrall, supra note 1): Arrow el al., supra note 2. at 222 (cılıng Morrall. supra note 1 ).

520. See, e.g., Gillette \& Hopkins, supra note 2. at 407 (suggestung that $" 10 \%$ is 100 high a rate"). Arrow et al., supra note 2, at 222 (arguing for the use of "a range of rates").

521. For criticism of the use of quantitative estimates of the distsbutional and revenue-relaled effects of tax legislation in the tax policymaking process. see Michael J. Graetz. Parmi-b3-Numbers Tat Lawmaking, 95 COLUM. L. REV. 609 (1995).

522. See sources cited supra note 517.

523. See, e.g., Christoph-Friedrich von Braun, Numbers-Magic and Mania, 18 INTERDisc. SCI. Rev. 59,59 (1993) ("Whoever can support his arguments with numbers is presumed to be nght.").

524. Richard Dusenbury \& M.G. Fennema, Linguistic-Numeric Presentation Mode Effects on Rishy Option Preferences, 68 Organizational Behav. \& Hum. Decision Processes 109. 119 (1996). 
Numbers are perilous not only because they appear objective and certain even when they are not, but also because they can so easily be transported across contexts. This is especially so when analysts purport to compress all of the relevant information about regulatory decisionmaking into one single number, such as cost per life saved. Indeed, a paramount reason to describe the costs and benefits of regulations in terms of a single number, such as cost per life saved, is precisely to enable comparisons and evaluations across different regulatory contexts. This means, however, that the number can easily be imported into inappropriate settings. This danger is evident in the role Morrall's table has played in the debate over whether regulation designed to save lives actually kills people by making them poorer. The claim is that the cost of regulation may itself increase risk through effects on personal income. In other words, "richer is safer": Income affects health, and so decreases in income brought about by regulation may impair health as well as wealth. ${ }^{325}$ Building on studies finding a correlation between wealth and health, researchers have attempted to identify the level at which regulatory expenditures will produce one fatality by reducing individual wealth. One frequently cited range of estimates for this level is $\$ 3$ million to $\$ 7.5$ million, based on a study by Ralph Keeney. ${ }^{526}$ Professor Viscusi's estimate is much higher: He reports that a regulatory expenditure of approximately $\$ 50$ million is required to induce one fatality. ${ }^{527}$

525. For the seminal statement of this hypothesis, see Aaron Wildavsky, Richer Is Safer, 60 PUB. INTEREST 23, 27-29 (1980).

526. See Ralph L. Keeney, Mortality Risks Induced by Economic Expenditures, 10 RISK ANALYSIS 147 (1990). For discussions relying on this estimate, see, for example, International Union, UAW v. OSHA, 938 F.2d 1310, 1326-27 (D.C. Cir. 1991) (Williams, J., concurring); BREYER, supra note 2, at 23; and Sunstein, Health-Health Tradeoffs, supra note 2, at 1544. There are numerous problems with such estimates. First of all, the wealth-health relationship may not work in the direction researchers like Kecney have assumed; that is, wealthy people might be wealthy partly because they are healthy, rather than the other way around. See, e.g., C.P. Wen et al., Anatomy of the Healthy Worker Effect: A Critical Review, 25 J. OCCUPATIONAL MED. 283, 283 (1983) (discussing studies suggesting that the "healthy worker effect" is a result of selection for employability, meaning that healthy people are the ones who get jobs). Keency, however, simply assumed that "higher incomes will lead to lower mortality risks." Keeney, supra, at 149.

Another problem with attempts to identify a uniform level at which regulatory costs will induce one fatality is that they ignore the fact that the relationship between health and wealth is "highly nonlinear." Paul R. Portney \& Robert N. Stavins, Regulatory Review of Environmental Policy: The Potential Role of Health-Health Analysis, in THE MORTALITY COSTS OF REGULATORY EXPENDITURES, supra note 2, at 111, 116. To put it another way, Donald Trump is not likely to be less healthy than Bill Gates because he has less money than Bill Gates. Thus, the actual distribution of regulatory costs in an individual case will make a large difference in determining whether the costs in fact impair anyone's health. Uniform estimates like Keeney's ignore this distributional variation.

527. See Viscusi, supra note 2 , at 1454 . Viscusi reaches this conclusion through the following reasoning. He asserts, based on his own studies of the wage premiums workers demand in order to accept small increases in risk on the job, that the value of a statistical life is approximately $\$ 5$ million. He also claims that the marginal propensity to spend on risk-reducing measures is approximately 0.1 . Thus, he concludes, if society had $\$ 50$ million to spend, it would spend $\$ 5$ million to save one life. If the $\$ 50$ million is unavailable to spend (because, for example, it has been spent on regulation), that life will not be saved, and thus one life will be lost through the $\$ 50$ million expenditure. See W. Kip Viscusi, Risk-Risk Analysis, in THE MORTALITY COSTS OF REGULATORY EXPENDITURES, supra note 2, at 5, 9-12. 
The important point for present purposes is not, however, the exact level of regulatory expenditures that will allegedly induce one fatality. It is that scholars have used Morrall's figures on costs per life saved to identify the regulations that are self-defeating in the way just described. Viscusi has argued, for example, that all of the regulations on Morrall's table with costs per life saved of more than $\$ 50$ million will induce one or more fatalities. ${ }^{528}$ Professor Sunstein has used the table for a similar purpose. ${ }^{329}$

Relying on Morrall's figures in this way ignores the large influence of discounting on his calculations. Without discounting, the cost per life saved of all but two of the regulations on Morrall's table is below even the level Keeney claims is necessary to induce one fatality. ${ }^{530}$ Discounting the benefits of regulation is particularly inappropriate, however, when one is trying to figure out how much money individuals may have to give up, out of pocket, as a result of a regulation (the determination relevant to the "richer is safer" analysis). Costs based on discounting future benefits do not reflect the amount that firms and individuals actually must spend, out of pocket, to respond to regulation. Indeed, even without discounting, costs per life saved do not reveal the amount of money actually spent on regulation. For example, imagine a regulation that costs one dollar to implement and eliminates, for one person, a 1-in-1,000,000 chance of dying. This regulation has a cost per life saved of $\$ 1$ million, but the absolute cost of the rule is only $\$ 1$. Absolute costs, not costs per life saved and not costs reflecting discounting, are the only costs that might, theoretically, increase risk by decreasing wealth. But absolute costs are not reflected in Morrall's table.

Using Morrall's table to show which regulations will kill people through effects on income thus ignores the basic assumptions and structure of the table. Representing the diverse consequences of regulation in a single number-costs per life saved-facilitates this misuse because the number itself does not declare its own limitations and assumptions.

\section{More Numbers?}

As for the second standard response to the observation that numerical representations of risks, costs, and benefits reflect normative choices-the response that encourages quantification of all the factors relevant to a decision, including the kinds of value choices I have been discussing-I would observe that this is exactly what Morrall himself did. His ten percent discount rate for

528. See Viscusi, supra note 2, at 1454-55.

529. See Sunstein, Health-Health Tradeoffs, supra note 2, at 1544-48 (noting that esumates of the level of regulatory costs inducing one fatality range from $\$ 3$ million to $\$ 12$ million. and pointing to Morrall's table as evidence that "some regulations fail health-health analysis whether or not they pass cost-benefit analysis").

530. See supra note 392. 
future lives saved, his adjustments to the agencies' estimates of risk, and his fixation on quantified benefits are part of an effort that incorporates normative choices in quantitative analysis. To say that the quantification of value choices is a solution to the problems with Morrall's table is thus to travel in a circle.

Even if one said that the solution is to incorporate a wider range of values in quantitative analysis-including, for example, incorporation of numerical representations of widely shared values such as autonomy, community, and equity-one would then simply generate a different set of numbers. But to figure out whether one agrees with the new set of numbers, or with Morrall's, one would have to dig underneath them to find the values that determine them. Once one does that, the numbers become irrelevant. If one agrees with Morrall's view of the relative value of lives today and lives tomorrow, for example, one will likely favor safety regulation, in general, over health regulation because, in general, it will produce more immediate benefits. ${ }^{331}$ One does not need Morrall's numbers to come to this conclusion.

In short, we are unduly credulous when it comes to numbers, and our numbers cannot, in this context, help but reflect our values. It is thus a mistake to assume, as many regulatory reformers have, that increased attention to "the numbers"-risks, costs, and benefits-will dilute the influence of politics and emotion on risk regulation. If no one believes that such numbers are neutral reflections of some factual reality, that is, if everyone sees that they reflect contestable choices about values, then a debate based on the numbers will be no more informed or informative than an explicit discussion about the values underlying the numbers, in which case one could dispense with the numbers altogether. The more likely scenario, however, is that some, probably many, people will be fooled into believing that numerical estimates of risks, costs, and benefits are impartial reflections of factual reality, in which case the likely result of increased reliance on quantification in setting regulatory policy will be that the side that best obscures the value choices implicit in its numbers will prevail. This will not produce more sensible regulation, but it will produce a more dishonest debate about regulation.

\section{Conclusion}

This is not to say that quantification has no role to play in regulatory policy. Instead, it seems to me that the practices I have described-discounting human lives, quantifying risks, and identifying regulatory purposes-all come to grief because they do not recognize the limits of extrapolation. They aspire to assess the benefits of regulation by reducing a large amount of data, some of it presented numerically, into a single number or range of numbers.

531. Naturally, this may not hold true in specific cases. See, e.8., supra notes 487.500 and accompanying text (discussing the regulation of unvented space heaters). 
Discounting and quantitative risk assessment, in particular, have this aim. Because we sometimes prefer ninety-nine lives saved today over 100 saved tomorrow, or because a substance has been associated with ten cases of cancer in a population of 100 workers, we think we must be able to identify how much we prefer today's lives over tomorrow's or how much risk is posed by the substance that has caused harm. And so, often with great misgiving, we force our intuitions about present and future lives, and our evidence about chemical harm, into theoretical models that allow us to bring those intuitions and that evidence into sharp focus, in a single number, transportable across contexts. Likewise, by quantifying some of the benefits of regulation, we begin to think we can quantify all of them, and we become convinced that if we cannot, they cannot be very important.

Thus, in sharpening the focus we distor the picture. It would be better, I think, if we left the picture blurry, and declined to connect the dots between all the confusing and sometimes conflicting intuitions and evidence. This would mean that, with respect to discounting, we would cease the search for the magic number that can convert future lives saved into present lives saved. With respect to quantitative risk assessment, we would stop massaging the same poor old databases with ever more sophisticated statistical models, which produce numerical point estimates that are either asserted to be too low or too high, never just right. And as for defining regulatory purposes, we would give up the faith that the things we can count are the worst things we have to fear.

\section{CONCLUSION}

John Morrall's table showing the costs per life saved of various federal regulations may be the single most widely cited piece of evidence in current critiques of the regulatory system. The critiques are familiar to any student of risk regulation: The costs of regulation often exceed its benefits; there are many more cost-effective strategies for reducing risk; regulation sometimes increases risk; the system is a crazy quilt. If one accepts the fantastic numbers at the bottom of the table, one is hard pressed to say these critiques are wrong.

I have sketched a different, more sympathetic portrait of current regulation. The regulatory system managed to catch some of the allegedly costliest regulations before they were ever implemented, on the precise ground that their benefits did not exceed their costs. It has also managed to save lives at a cost that compares favorably to current estimates of the monetary value of human life while at the same time reducing risks to human health that cannot be quantified, risks to the environment, and risks to values that are widely shared. Certainly, even on this view, the regulatory system can produce some clunkers. But the overall picture is of a system striving to achieve a broad range of regulatory purposes and doing so at a reasonable cost. 
One cannot consult a table in order to determine whether Morrall's vision, or mine, is correct. In order to choose between them, one must instead grapple with a range of fundamental issues, such as the relative worth of lives saved today and lives saved tomorrow, the proper response to scientific uncertainty, and the purposes of environmental law. I have tried to show how a normatively plausible perspective on each of these issues would lead one to a sympathetic, rather than unsympathetic, account of current regulation. I have also suggested that embedding these normative choices in a table of numbers makes serious engagement with these important issues unlikely, as experience with this particular table has indeed shown.

Many thoughtful scholars of the regulatory process have embraced the numerical results of Morrall's table, seemingly without attention to the problematic legal status of many of the rules in the table or to the wide divergence between Morrall's numbers and the agencies' own estimates of risks and costs. These numbers are beguiling because they promise objectivity and clarity. But the numbers in tables like Morrall's and mine tell us more about our preexisting values than they do about the subjects under study. At best, these numbers can only confirm what we already know or fear. At worst, they derail thoughtful discussion by offering the illusion of objective accuracy. The debates that have grown out of Morrall's table illustrate this danger. These debates have taken Morrall's table to be the starting point of discussion rather than the conclusion of a process of moral inquiry. The table is a Trojan horse that has been wheeled into the debate over regulatory reform, loaded with the values the debate is supposed to be about. 